Федеральное государственное автономное учреждение здравоохранения Больница Пущинского научного центра Российской академии наук

\author{
Н.И. Косякова, М.В. Захарченко, \\ Т.В. Сандалова, Н.В. Шибаев, \\ Е.В. Панкратова, М.Н. Кондрашова
}

\title{
ПРИМЕНЕНИЕ ЦИТОБИОХИМИЧЕСКОГО МЕТОДА ИЗМЕРЕНИЯ АКТИВНОСТИ ФЕРМЕНТОВ В КАПЛЕ КРОВИ ПРИ ХРОНИЧЕСКОЙ ОБСТРУКТИВНОЙ БОЛЕЗНИ ЛЕГКИХ И БРОНХИАЛЬНОЙ АСТМЕ
}

Методические рекомендации

по внедрению результатов научно-поисковой работы 
УДК 577.152.53:616.155.32:57.086:[616.36-002-099-092.9:615.272’476.4]

ББК 53/57-54.1-53.54

K71

Согласовано Научно-координачионный совет БПНЦ РАН.

Протокол № 13 от 21 ноября 2017 г.

Косякова Н.И., Захарченко М.В., Сандалова Т.В., Шибаев Н.В., Панкратова Е.В., Кондрашова М.Н.

К71 Применение цитобиохимического метода измерения активности ферментов в капле крови при хронической обструктивной болезни легких и бронхиальной астме / Н.И. Косякова, М.В. Захарченко, Т.В. Сандалова, Н.В. Шибаев, Е.В. Панкратова, М.Н. Кондрашова. - М.: Издательский дом Академии Естествознания, 2021. - 68 с.

ISBN 978-5-91327-688-9

DOI 10.17513/np.465

Актуальная проблема современной передовой персонализированной медицины определение состояния митохондрий (MX) у человека. Принятые биохимические методы повреждают и весь организм (требуется биопсия), и, что не менее важно, сами выделенные МХ. Исследования в лаборатории биоэнергетики ИТЭБ РАН под руководством д.б.н., проф. М.Н. Кондрашовой позволили разработать метод оценки тяжести заболевания по измерению энергетических процессов в митохондриях лимфоцитов в капле крови. Оригинальный метод, названный цитобиохимическим (ЦБХ), позволяет оценить активность митохондрий и гликолиза в лимфоцитах крови пациента, создан специально, чтобы сохранить в выделенных препаратах нативную организацию митохондрий в сеть, что позволяет наблюдать в них регуляцию, имевшую место в организме.

Работами М.Н. Кондрашовой было показано, что активность митохондрий связана с деятельностью общих физиологических систем регуляции, в частности симпатической и парасимпатической. Между симпатической и парасимпатической регуляцией в организме существуют взаимно противоположные, реципрокные отношения подавления активности противоположной системы при активации ее партнера. Подобная реципрокная регуляция существует и на митохондриальном уровне: в пределах физиологической нормы симпатическая активация усиливает энергетическое обеспечение физиологических функций за счет усиления распада жиров и углеводов. Однако симпатическая гиперактивация приводит к дисбалансу между процессами катаболизма и восстановительными биосинтетическими процессами, и это формирует дополнительный порочный метаболический круг развития патологии на уровне клеточного дыхания. Особенно выражены такие нарушения при хронических респираторных заболеваниях, что и послужило целью настоящего исследования: изучить показатели активности митохондриального фермента - сукцинатдегидрогеназы (СДГ) и фермента гликолиза - лактатдегидрогеназы (ЛДГ) у пациентов с атопической бронхиальной астмой (АБА). Это позволит получать новую информацию для исследователя и врача, на ранних стадиях развития патологического процесса распознать его и внести необходимые коррективы в тактику лечения и реабилитации пациентов с респираторной патологией.

Рекомендации предназначены для специалистов клинико-биохимических лабораторий ЛПУ, терапевтов, пульмонологов, иммунологов-аллергологов.

ISBN 978-5-91327-688-9 (с) Н.И. Косякова, М.В. Захарченко, Т.В. Сандалова, Е.В. Панкратова, Н.В. Шибаев, М.Н. Кондрашова, 2021

(C) ИД «Академия Естествознания»

(C) АНО «Академия Естествознания» 


\section{СОДЕРЖАНИЕ}

Введение ................................................................................. 4

Описание технологии …..................................................................... 9

Полученные результаты ..................................................................... 18

Технология внедрения полученных результатов …............................... 24

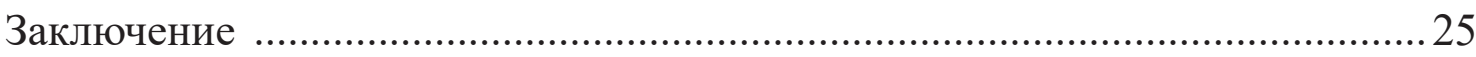

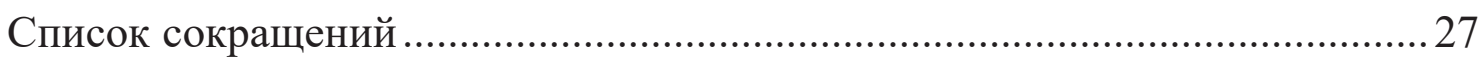

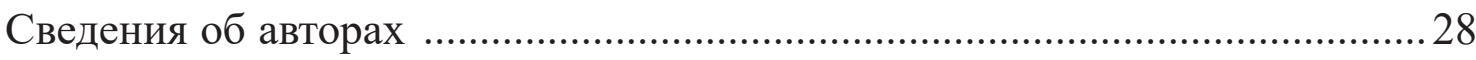

Перечень опубликованных работ, выступлений, наличие патента

по теме методических рекомендаций за последние три года

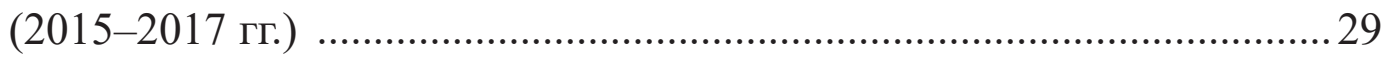

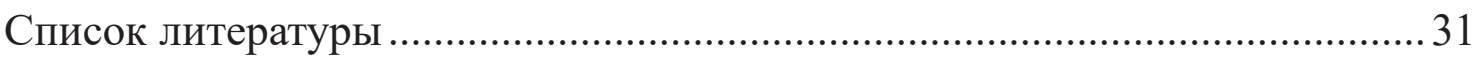

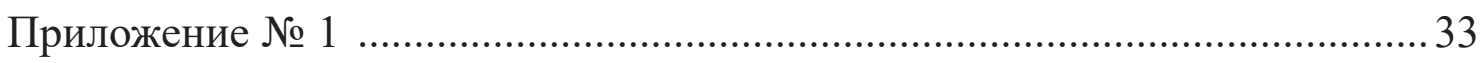

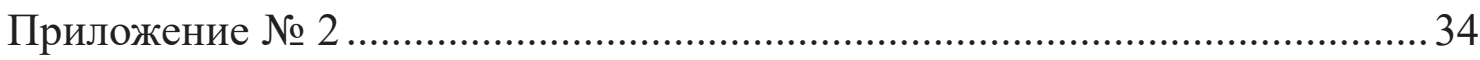

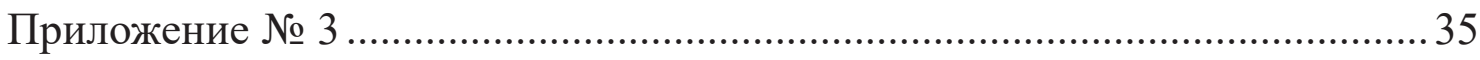

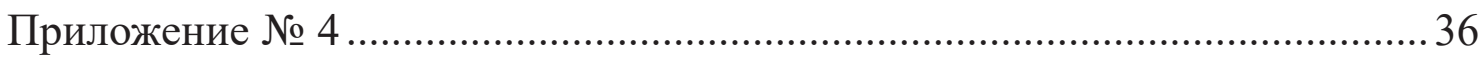

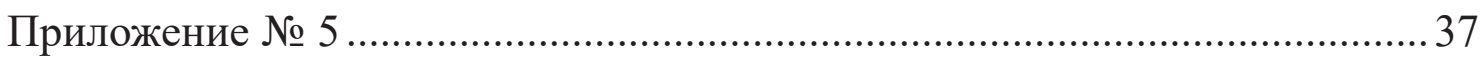

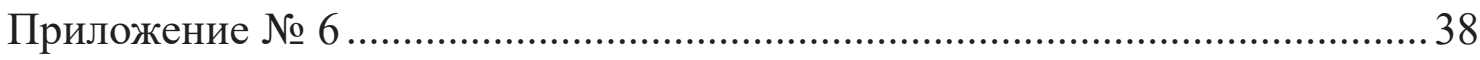

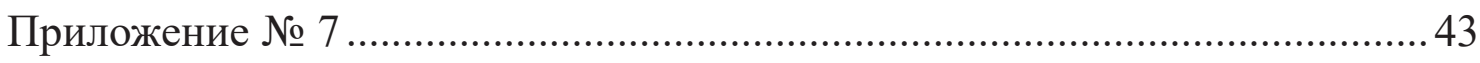

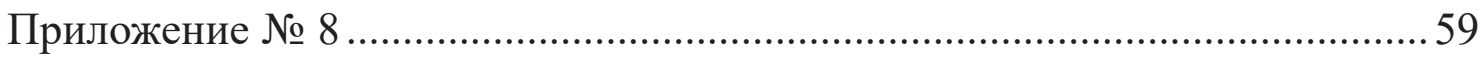

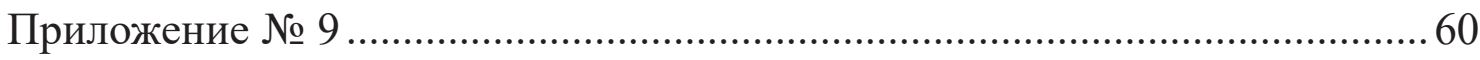

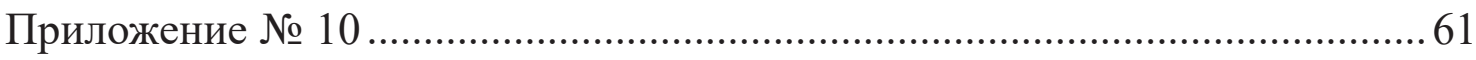

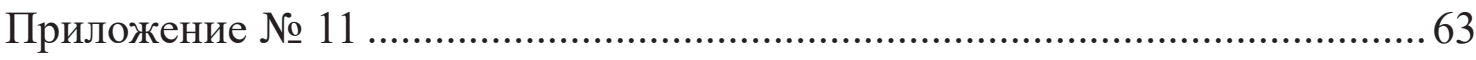

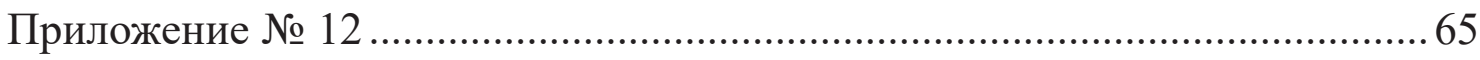

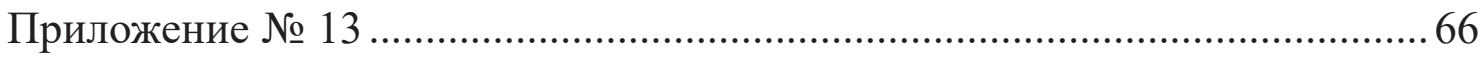

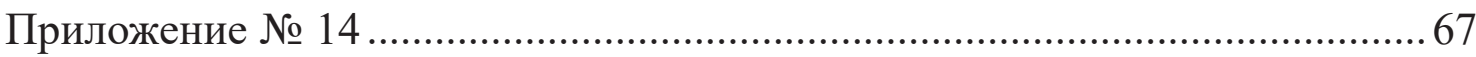




\section{ВВЕДЕНИЕ}

В центре энергетики клетки, а следовательно, и жизнедеятельности всего организма лежат митохондрии - органеллы которые объединяют основные метаболические потоки в клетке. Изменения энергетического обмена являются неспецифической основой всех адаптивных реакций. Именно обеспеченность или недостаток энергии определяют дальнейшую цепь регуляторных, метаболических и структурных изменений в организме. Установлена ведущая роль митохондрий в формировании многих физиологических и патологических состояний.

В связи с установлением ключевой роли митохондрий в состоянии клеток остро актуальной для митохондриальной медицины стала разработка способа определения митохондриальных процессов в организме человека. Однако этот запрос встречает препятствие для использования на человеке, поскольку при этом надо проводить болезненную, небезопасную биопсию.

Многолетние исследования под руководством М.Н. Кондрашовой, позволили разработать метод оценки тяжести заболевания по измерению энергетических процессов в митохондриях лимфоцитов в капле крови - цитобиохимический (ЦБХ) метод. Данный метод позволяет выявить существенные изменения уровня митохондриальных ферментов при таких патологических процессах, как гипертоническая болезнь, аллергия и онкологические заболевания. Эти результаты получены в совместных поисковых исследованиях ИТЭБ и БПНЦ. Изменения регистрируются также и при эмоциональном возбуждении у практически здоровых и у лиц без клинических проявлений при воздействии неблагоприятных факторов окружающей среды. (Патент Российской Федерации. № 2364868. ИТЭБ РАН, Кондрашова М.Н., ОАО ДИОД, Захарченко М.В., Хундерякова Н.В., Маевский Е.И. Цитобиохимический способ определения активности сукцинатдегидрогеназы, окисления эндогенной янтарной кислоты, сигнального действия микромолярных концентраций янтарной кислоты, его применение для количественной оценки уровня адренергической регуляции в организме, среда и набор для осуществления способа. Приоритет от 20.11.2007. Бюллетень Роспатента. 20.08.09.).

Несомненно, что своевременное выявление неблагоприятных сдвигов внутриклеточной энергетики позволит проводить профилактические мероприятия, направленные на предотвращение развития отрицательных сдвигов в состоянии здоровья и оптимизацию процессов адаптации.

Предлагаемые методические рекомендации направлены на внедрение ЦБХ метода в практику клинических исследований, что позволит значитель- 
но углубить понимание механизмов повреждений при заболеваниях и разработку новых способов коррекции или предупреждения патогенных сдвигов, в том числе направленных на регуляцию состояния митохондрий их природными метаболитами. На основе цитобиохимического метода, положенного в основу данных исследований, возможно развитие нового направления персонифицированного подбора лечебных средств на мазке крови данного больного. Это существенно повысит прицельность выбора назначений.

\section{Актуальность проблемы}

Разработка показателей изменения метаболизма в организме человека как биомаркеров нарушений здоровья является актуальной задачей современной медицины. Всевозрастающий интерес вызывает выявление индивидуальной характеристики состояния силовых станций клетки - митохондрий, как основы энергообеспечения функций тканей.

Особенно важно обнаружение начальных стадий патологических изменений, которые не выявляются по клиническим проявлениям и отражают разный уровень здоровья. Одновременно это и более трудная задача - измерение тонких различий метаболизма в клетке. Сильные изменения проявляются четче - такие как отличия раковых клеток от нормальных или изменения при грубых моделях патологии, например, инфаркта. Также отчетливо измеряются реакции митохондрий на добавки физиологически активных веществ in vitro.

Первоначальные нарушения процессов энергообеспечения в митохондриях происходят до клинических проявлений заболеваний. Раннее выявление и возможная коррекция этих нарушений могут значительно повысить эффективность профилактики и лечения заболеваний. Поэтому современная медицина требует новых методов, которые бы позволили исследовать энергетический обмен конкретного человека, чтобы осуществить индивидуализированную диагностику и оптимизацию состояния.

В основе группы типичных болезней современности, таких как стресс, гипертония, диабет, лежит общее нарушение нормального баланса метаболизма липидов и углеводов, названное метаболическим синдромом. Он является следствием симпатической гиперактивации.

Регуляция тонуса бронхиальной мускулатуры и, следовательно, состояние бронхиальной проходимости также зависит от сбалансированности симпатической и парасимпатической иннервации бронхов, а также от соотношения и активности адренорецепторов бронхиального дерева угнетение $\beta 2$-адренорецепции ведет к преобладанию эффекта стимуляции $\alpha$-рецепторов и к развитию бронхоспазма.

Между симпатической и парасимпатической регуляцией в организме существуют взаимно противоположные, реципрокные отношения подавления активности противоположной системы при активации ее партнера. Подобная реципрокная регуляция присуща совершенным регуляторным системам на разных уровнях. Работами группы М.Н. Кондрашовой 
[1-5] в лаборатории энергетики биосистем ИТЭБ РАН показано, что симпатическая регуляция связана с митохондриями через янтарную кислоту (ЯНТ) и фермент, ее окисляющий - сукцинатдегидрогеназу (СДГ). Таким образом, представляется, что изменение активности СДГ будет иметь особенно большое диагностико-информационное значение. Такое понятие о ключевой роли СДГ в энергообеспечении функциональной деятельности согласуется с работами последнего времени, показывающими определяющую роль нарушений СДГ в развитии ряда заболеваний, включая онкологические. Разработанный в лаборатории подход к диагностике функциональных состояний через активность СДГ представляет преимущество не только самим объектом - данным ферментом, но и методом его измерения. Оригинальный метод, названный цитобиохимическим, создан специально, чтобы максимально сохранить в выделенных препаратах нативную организацию митохондрий в сеть, что позволяет наблюдать в них регуляцию, имевшую место в организме $[6,7]$. Кроме того, работа проводится в микрокапле крови, что позволяет широко применять метод в клинике в отличие от обычных способов, требующих взятия биоптата ткани.

Использование разработанного чувствительного метода комплексной оценки функционального состояния организма в клинической практике расширит возможности применения результатов фундаментальных исследований в области медицины и физиологии.

Цель исследования - получить характеристики состояния пациентов по пробам, характеризующим мощность энергообеспечения - соотношения активности СДГ с интенсивностью гликолиза, измеряемого по активности лактатдегидрогеназы (ЛДГ). Это отражает важнейший показатель энергообеспечения - способность митохондрий сдерживать гликолиз эффекты Пастера и Варбурга; провести исследования специфических митохондриальных ферментов у «нативных» пациентов с впервые выявленным диагнозом БА и ХОБЛ, а также на фоне стандартной терапии и с включением препаратов, влияющих на активность митохондриальных ферментов, разрешенных МЗ РФ.

Научная новизна. Многими исследователями и некоторыми фирмами предлагаются усовершенствованные технические устройства для измерения функций митохондрий, преимущественно дыхания. Все модификации для клинических исследований касаются только технической стороны используемых устройств. Она состоит в создании более миниатюрных ячеек, позволяющих работать с меньшими объемами ткани, что обусловлено необходимостью работы с очень малыми количествами биоптатов мышц больных. При разработке технических устройств не обращается внимания на самое главное - состояние самого исследуемого образца ткани, так как получение митохондрий из малого количества ткани само по себе повреждает их. 
Многолетние исследования группы под руководством М.Н. Кондрашовой посвящены проблеме возможно более полного сохранения выделенными препаратами митохондрий их нативного состояния в клетке, где они составляют разветвленную сеть, тесно связанную с другими компонентами клетки [8-12]. Как правило, выделение МХ из клетки для проведения исследований приводит к разрушению сети. Оригинальными исследованиями, которые сочетали микроскопическое наблюдение организации MX с биохимическим изучением их функций, установлено, что потеря структурной организации МХ в клетке приводит к повреждению их функций. Наш вывод согласуется с современными данными прижизненной микроскопии о том, что динамика - структурные перестройки сети тесно связана и является фактором регуляции функциональных состояний MX, чему был посвящен специальный выпуск журнала IJCB [13]. В собранном виде она находится в покое с низкой активностью окислительных ферментов. А при возбуждении адреналином сеть распадается и МX переходят в активное состояние.

Самый яркий пример регуляторного действия МХ на состояние организма был описан недавно. Переключение ВСЕГО ОРГАНИЗМА на распад углеводов или жиров УПРАВЛЯЕТСЯ, как известно, гипоталамусом. А механизм этого управления - различное расположение МХ в клетках - ближе к ядру или, наоборот, к наружной мембране. Это расположение задается структурой сети в единичных клетках гипоталамуса [14]. Получается, что расположение МХ в этих клетках играет роль ГЛАВНОКОМАНДУЮЩЕГО метаболизмом во всем теле.

В ИТЭБ РАН разработан цитобиохимический способ исследования митохондрий в неповрежденных лимфоцитах крови на мазке в тщательно подобранных средах, близких к условиям в организме. ЦБХ методом удается выявить выраженные изменения митохондрий при таких заболеваниях, как гипертоническая болезнь, аллергия и онкологические заболевания. Эти результаты получены в совместных поисковых исследованиях ИТЭБ и БПНЦ. Сильные изменения выявляются и при эмоциональном возбуждении без патологии и у здоровых при повышении риска заболеваний без проявления клинических симптомов. Это позволяет выявить неблагоприятное воздействие факторов среды или перегрузки организма.

Таким образом, митохондриальная медицина впервые получает собственный диагностикум. Оригинальность метода подтверждена патентом РФ [6]. О значимости работы свидетельствуют публикации в специальном выпуске международного журнала, посвященного исследованиям митохондрий в медицине и нескольких других отечественных и международных изданиях [5, 8, 12, 15 и др.]. Для внедрения метода в клиническую практику проводится педагогическая работа, публикации методических разработок и статей, адресованных врачам. 
Изучение изменений митохондриальных ферментов в динамике у пациентов с ХОБЛ с частыми обострениями позволит выявить закономерности течения хронического воспалительного процесса, определить показания к выбору препаратов базисной терапии и назначению природных метаболитов янтарной кислоты для их коррекции и сможет служить прогностическим маркером тяжести течения заболевания. На основе этого метода возможно развитие нового направления персонифицированного подбора лечебных средств на мазке крови данного больного. Это существенно повысит прицельность выбора назначений.

Внедрение ЦБХ метода в практическое здравоохранение позволит значительно улучшить диагностику нарушений энергетического обмена. 


\section{ОПИСАНИЕ ТЕХНОЛОГИИ}

Уровень доказательств и сила рекомендаций каждого положения методических рекомендаций взвешены и оценены в соответствии с известными шкалами Классы рекомендаций и Уровень доказательств. Уровень доказательств А - С, классы рекомендаций I, II, IIA, IIB.

Классы рекомендаций

\begin{tabular}{|c|c|c|}
\hline $\begin{array}{c}\text { Класс } \\
\text { рекомендаций }\end{array}$ & Описание & $\begin{array}{c}\text { Предлагаемое } \\
\text { использование в практике }\end{array}$ \\
\hline I & $\begin{array}{l}\text { Доказательства и/или общее соглашение, } \\
\text { что данный метод лечения или диагностики } \\
\text { полезен и эффективен }\end{array}$ & Рекомендуется/показан \\
\hline II & $\begin{array}{l}\text { Спорные доказательства и/или расхожде- } \\
\text { ния во мнении экспертов о пользе/эффек- } \\
\text { тивности данного метода лечения или диа- } \\
\text { гностики }\end{array}$ & $\begin{array}{l}\text { Следует рассмотреть при- } \\
\text { менение данного метода }\end{array}$ \\
\hline IIA & $\begin{array}{l}\text { Доказательства/мнение экспертов склоня- } \\
\text { ются в сторону эффективности/пользы }\end{array}$ & $-\gg\rangle-$ \\
\hline IIB & $\begin{array}{l}\text { Эффективность/польза менее подтвержде- } \\
\text { ны доказательствами/мнением экспертов }\end{array}$ & $\begin{array}{l}\text { Применение данного ме- } \\
\text { тода может обсуждаться }\end{array}$ \\
\hline III & $\begin{array}{l}\text { Доказательства и/или общее соглашение, } \\
\text { что данный метод лечения или диагностики } \\
\text { бесполезен и неэффективен, а в отдельных } \\
\text { случаях может нанести вред }\end{array}$ & Не рекомендуется \\
\hline
\end{tabular}

Уровень доказательств

\begin{tabular}{|c|l|}
\hline Уровень доказательств & \multicolumn{1}{|c|}{ Источник данных } \\
\hline А & $\begin{array}{l}\text { Многочисленные рандомизированные клинические исследова- } \\
\text { ния и метаанализы }\end{array}$ \\
\hline В & $\begin{array}{l}\text { Отдельные или крупные рандомизированные клинические ис- } \\
\text { следования, нерандомизированные клинические исследования }\end{array}$ \\
\hline C & $\begin{array}{l}\text { Согласительное мнение экспертов и/или небольшие исследова- } \\
\text { ния, ретроспективные исследования, регистры }\end{array}$ \\
\hline
\end{tabular}

Известно, что гетерогенная популяция лимфоцитов в крови здорового человека находится в состоянии относительного покоя и для удовлетворения энергетических потребностей используют митохондрии, т.е. окислительное фосфорилирование (ОФ) [16]. Тот факт, что в нормальных клетках доминирует дыхание, известен давно. Он называется Пастеровским эффектом. Было 
выявлено много его механизмов, но основным ранее было мнение, что полнота подавления гликолиза определяется мощностью дыхания в клетке, что позволяет ему выигрывать в конкуренции за фосфат и АДФ. В отличие от здоровых, в раковых клетках, даже в аэробных условиях, гликолиз интенсивнее дыхания. Это явление открыто Отто Варбургом более ста лет назад и называется эффектом Варбурга (ЭФВ). Интерес к нему переживает в настоящее время новый подъем ввиду возможного использования для диагностики и контроля развития опухолей у больных. Однако оказалось, что этот метаболический фенотип не уникален для опухолей. Те же метаболические переходы к аэробному гликолизу характерны для лимфоцитов при активации, независимо от этапов трансформации. Стимуляция лимфоцитов (а известно, что при астме происходит хроническая активация Т-клеток) ведет к чрезвычайно высокой скорости роста и пролиферации. Поэтому для обеспечения энергетических и биосинтетических потребностей активированные Т-клетки быстро увеличивают потребление глюкозы $[17,18]$. В других работах активация лимфоцитов ассоциирована с переключением метаболического фенотипа с увеличением и гликолиза, и ОФ $[19,20]$.

Для выявления переключения путей окисления мы использовали в качестве биомаркеров этих процессов два фермента - СДГ, как показатель энергетических функций цикла трикарбоновых кислот, и ЛДГ, как показатель одного из восстановительных путей поддержания биосинтезов - гликолиза и его динамического фонда взаимопревращений молочной и пировиноградной кислот. СДГ является ключевым ферментом, характеризующим окислительную активность митохондрий. Исследования последних лет показали, что СДГ также является и мишенью и посредником действия адреналина/ норадреналина в митохондрии. Активность СДГ избирательно активируется при экспериментально вызванном усилении адренергической регуляции в организме. Лактатдегидрогеназа - один из ферментов, который участвует в распаде глюкозы до молочной кислоты; ее активность может считаться характеристикой интенсивности гликолиза в клетке.

Активность ферментов в лимфоцитах определяют в мазке крови, полученном при проколе пальца, без добавления антикоагулянтов авторским цитобиохимическим (ЦБХ) методом.

Последовательность процедур ЦБХ метода:

1. Получение мазка крови, высушивание.

2. Фиксация $60 \%$ ацетоном 30 с, высушивание.

3. Инкубация с субстратами (ЯНТ и ЛАК), приводящая к восстановлению нитросинего тетразолия (НСТ) и образованию в клетках нерастворимых гранул формазана, имеющих синюю окраску. Активность ферментов определяется по интенсивности синего окрашивания. Высушивание.

4. Окраска 0,05 \% раствором нейтрального красного (НК) для окраски ядер и облегчения последующей идентификации клеток крови. Высушивание. 
5. Микроскопирование под масляной иммерсией при увеличении 6,3 x 100/1,30. Для анализа на мазке необходимо найти и сфотографировать около 100 лимфоцитов с помощью специальной программы по захвату изображений.

6. Обработка полученных фотографий лимфоцитов специальной программой для получения количественных показателей активности ферментов по интенсивности синей окраски.

7. Статистическая обработка полученных показателей (вычисление средних, построение диаграмм и пр.).

Ниже подробно описаны все этапы, требуемые для проведения обследования и получения информации об активности исследуемых ферментов.

Реактивы, необходимые для описанных процедур, приведены в табл. 1 Приложения 1.

\section{Оборудование и посуда}

1. Автомат для приготовления мазков V-sampler, Vision, Австрия.

2. Водяной термостат для поддержания постоянной температуры $+37{ }^{\circ} \mathrm{C}$ (например, марки TW-2).

3. $\mathrm{pH}$-метр чувствительностью $\pm 0,01$ (у нас $\mathrm{pH}$-метр Mettler Toledo FE20-Kit, стеклянный рH-электрод LE409 в комплекте).

4. Магнитная мешалка.

5. Холодильник с морозильной камерой.

6. Микроскоп с видеокамерой (у нас Leica DM-2000 видеокамера Leica DFC 425).

7. Компьютер с программами для обработки видеоизображения.

8. Предметные обезжиренные стекла: стекло предметное Heinz Herenz, 26 х 76 мм, 1 мм, матовое поле, 50 шт/уп.

9. Контейнер для предметных стекол.

10. Стеклянные стаканчики разных объемов 250 мл - 2 шт, 50 мл -7 шт, мерный цилиндр до 300 мл; стандартные пластиковые стаканчики для окрашивания мазков крови.

11. Кювета типа «Шиффердекер» для окрашивания 10 стекол, горизонтальная, полиметилпентан, Nuova Aptaca - удобно для окрашивания нейтральным красным.

12. Автоматические пипетки 2 шт до 1 мл и до 100 мкл и наконечники к ним.

13. Таймер.

\section{Поддержание рН 7,2 $\pm 0,01$}

Выбор рН 7,2 и поддержание его с высокой точностью в среде инкубации являются одним из существенных условий разработанного нами метода. В предшествующих работах использовали $\mathrm{pH}$ в широком диапазоне от величин ниже 7,2 и до более щелочных, чем 7,6, значений (преимущественно использовался диапазон 7,2-7,5, причем не указывается критичность точного значения этого показателя). 


\section{1. Приготовление мазка крови}

В ЦБХ методе носителями свойств исследуемого организма выступают лимфоциты в мазке крови. Метод базируется на принципах сохранения целостности MX сети в лимфоцитах, что не удается достичь другими биохимическими исследованиями. Это обеспечивается тщательно разработанными условиями проведения экспериментов. Даже, казалось бы, небольшие изменения методики могут сильно изменить состояние и лимфоцитов на мазке, и митохондрий внутри них. И самым первым шагом сохранения целостности лимфоцитов на мазке является его приготовление.

\section{Взятие крови}

Взятие крови для ЦБХ метода проводится утром, натощак, до приема лекарственных средств и пищи. Рекомендуется накануне исследования не принимать алкоголь и жирную пищу. В ЦБХ методе особое внимание следует уделять качеству мазков (см. ниже). В условиях клинической лаборатории лаборантам следует учитывать, что не все мазки, получаемые для обычных рутинных исследований крови, например для определения лейкоформулы, могут быть пригодны для ЦБХ. В целом процедура взятия крови такая же, но есть обязательные требования, без которых не получится дальнейшая обработка взятого материала.

Для исследования можно брать кровь из вены или пальца без антикоагулянта. Сразу после того как шприц набран, иглу снимают и выдавливают из шприца небольшое количество крови (около 0,2 мл) на часовое стекло. Из этой большой капли кровь автопипеткой по 8 мкл наносят на предметное стекло и делают мазки (см. далее). Если кровь берется из капли, выступающей из мякоти пальца, после укола скарификатором важно, чтобы прокол был широким - это первое указание, основанное, можно смело сказать, на более чем вековом опыте - для сохранения неповрежденных клеток кровь должна свободно капать из пальца при взятии. Для этого необходимо пользоваться скарификатором, а не другими приспособлениями (применение ручки для глюкометра исключается, так как из-за малого диаметра прокола клетки повреждаются). Скарификаторы бывают трех видов: детские (копье 1,5 мм), средние универсальные (копье 3 мм) и глубокие, или мужские (копье до 5 мм). После прокола скарификатором первая капля не используется (вытирается сухой ваткой), при легком сдавливании пальца кровь свободно капает на отдельное предметное стекло, нужно 4-5 капель. Потом из этой большой капли автоматической пипеткой-дозатором нужно быстро взять 8 мкл крови и нанести на край другого предметного стекла и приготовить мазок (об этом подробно ниже).

На основании своих исследований мы исключаем добавление антикоагулянтов, которые меняют содержание кальция, опасен также контакт со спиртом. Чтобы предупредить свертывание крови при приготовлении мазков, время забора крови должно составлять не более 10 с на один мазок. 


\section{Приготовление мазков крови при помощи автоматического прибора}

Для стандартизации получаемых мазков, что является необходимым условием получения достоверных результатов, мы настоятельно рекомендуем пользоваться автоматическими устройствами для изготовления мазков (V-Sampler Vision, West Medica, Австрия, HemaPrep, Германия и других). В них, регулируя скорость движения пластин и их нажим, можно задавать толщину и длину мазка, что позволяет получать стандартизованные мазки заданной толщины, в том числе в виде монослоя.

На протяжении многих десятилетий в клинической практике мазок крови готовили вручную: капля крови размазывается по стеклу другим стеклом со шлифованным краем. Теоретически должен получаться слой клеток, равномерно убывающий по своей толщине к концу мазка - так называемой «щетке». С целью улучшения микроскопирования стараются уменьшить толщину мазка, чтобы получить монослой клеток, для чего используют малые количества крови - 2-4 мкл. Известно, что толщина мазка сильно влияет на морфологию клеток: так, по краям и в конце мазка, так называемой «щетки», клетки максимально распластаны и их морфология хорошо видна. Для подсчета лейкоформулы рекомендуют исследовать именно эти участки.

В начале мазка клетки, где слой намного толще, лимфоциты мало распластаны, удерживая форму в виде полусферы, и в них трудно увидеть морфологические отличия. Но именно на этом участке клетки максимально интактны, что является важным фактом для ЦБХ метода, где исследуется активность ферментов в неповрежденных клетках. Поэтому при приготовлении мазка для ЦБХ исследований стоит задача приготовить мазок оптимальной толщины, при которой будут сохранены условия для качественной микроскопии клеток, при этом достаточное внеклеточное окружение лимфоцитов защитит их от набухания и повреждения.

Кроме того, в клинической практике хорошо известно, что мазки, изготовленные разными людьми, отличаются по качеству и их толщина имеет на протяжении мазка величины, далекие от стандарта. Наконец, при изготовлении мазков одним человеком они тоже могут варьировать по качеству. Поэтому многие годы в клинических исследованиях бытовал обычай в особенно ответственных случаях проводить работу одному и тому же лаборанту.

Нами были разработаны условия приготовления мазка крови, в которых соблюдаются вышеизложенные требования - оптимальная толщина, однородность и стандартность мазка.

Для этого определены следующие настройки автомата для приготовления мазков (разработаны для V-Sampler, Vision, см. инструкцию для применения).

Регулятор толщины мазка: вертикально (средняя настройка).

Настроить винт настройки остановки, так, чтобы время остановки рычага внизу составляло 2 с. 
В результате прибор должен быть настроен таким образом, чтобы получался мазок длиной приблизительно 4 см (вместе с каплей), И ярко выраженной щеткой, заканчивающейся за 1 см до края стекла.

Таким образом, для получения стандартного однородного мазка оптимальной толщины необходмо поместить предметные стекла в соответствующие гнезда на автомате, набрать авт. пипеткой точно 8 мкл крови и нанести на каждое стекло в местах, отмеченных точками в углублениях для предметных стекол. Нажать на рычаг.

Примеры правильных и неправильных мазков приведены на рис. 1 Приложения 2: А и Б - неправильно приготовленные мазки; В - мазок подходит для исследования ЦБХ методом.

Полученные мазки подсушиваются при комнатной температуре в горизонтальном положении около 20 мин. Мазки готовы к фиксации

\section{2. Фиксация}

Фиксацию можно проводить через 20 мин после взятия крови, но не позднее 5-6 ч после получения. Если дольше нет возможности покрасить мазки, то следует зафиксировать после взятия через 20-30 мин, перевозить мазки крови уже зафиксированными. Фиксированные мазки хранятся до покраски НСТ не более 4 ч, после этого времени активность ферментов начинает снижаться и полученные результаты будут недостоверными. Перевозить стекла следует в сухих темных коробках с температурой не ниже +4 и не выше $+25{ }^{\circ} \mathrm{C}$. Более длительное хранение неокрашенных мазков специально не исследовалось, поэтому лучше уложиться в рекомендуемые сроки, чтобы не утратилась активность ферментов на мазке.

Фиксация осуществляется погружением стекла в 60 \% раствор ацетона на 30 с при легком помешивании, при комнатной температуре.

После окончания фиксации мазки ополаскивают дистиллированной водой аккуратными погружениями стекла в стаканчик в течение 5 с и высушивают на воздухе (30 мин) в вертикальном положении и переходят к проведению реакции восстановления НСТ.

Фиксирующий раствор ацетона (60 \%)

Фиксирующая смесь - прозрачный бесцветный раствор, содержащий 60 мл ацетона +40 мл. бд. воды +238 мг HEPES (10 мМ). Раствор имеет рН 5,2-5,4. Работа с ацетоном проводится под тягой.

Если фиксируется не более 60-70 мазков в месяц, раствор может храниться при комнатной температуре в течение 1 мес. в защищенном от света месте. При фиксации большего количества мазков рекомендуется менять раствор через 2 недели. Раствор становится непригодным при появлении розовой окраски и мутных хлопьев.

\section{3. Проведение реакции восстановления НСТ}

Фиксированные мазки инкубируют в наборе сред с субстратами в течение 1 ч при $37^{\circ} \mathrm{C}$ в водяном термостате. Среда состоит из среды инкубации 
(СИ) с добавлением непосредственно перед инкубацией раствора субстрата (так называемого «матричного раствора»).

\section{Приготовление среды инкубации (СИ)}

Состав среды инкубации:

КС1 125 мM,

Hepes $10 \mathrm{mM}$,

НСТ 1 мг/мл,

$\mathrm{pH} 7,2 \pm 0,01$.

В зависимости от используемой для инкубации мазков посуды, объем среды на одну пробу варьирует от 10 до 40 мл; следовательно, для приготовления двух проб потребуется около 20-80 мл СИ.

Среду инкубации следует готовить в день эксперимента.

При приготовлении среды инкубации необходимо использовать бидистиллированную воду температурой $37^{\circ} \mathrm{C}$.

Навески веществ добавляют в объем воды на 10-20 мл меньше требуемого конечного объема (Приложение 3, табл. 2). Получается раствор желтого цвета со слабым неприятным запахом и не полностью растворенным НСТ. Взвесь размешивают в течение 5-10 мин на магнитной мешалке. После полного растворения НСТ доводят $\mathrm{pH}$ до величины 7,2 \pm 0,01 при поддержании температуры $37^{\circ} \mathrm{C}$. Если довести $\mathrm{pH}$ до 7,2 при комнатной температуре $\left(20-24{ }^{\circ} \mathrm{C}\right)$, а потом нагреть этот же раствор до $37{ }^{\circ} \mathrm{C}$, то $\mathrm{pH}$ в таком растворе будет меньше - 7,0-6,9.

Доведение рН среды инкубации проводят с помощью фиксанала или самостоятельно приготовленного $0,1 \mathrm{H}$ и 0,01 Н раствора КОН. Чтобы не перетитровать среду инкубации, 1-2 каплями 0,1 Н раствора КОН доводят pH среды до 6,8-7,0. Последующую точную дотитровку до pH 7,2 аккуратно проводят более разбавленным раствором КОН (0,01 Н). После доведения рН среды инкубации доводят объем среды до требуемого конечного объема.

Приготовление растворов субстратов (так называемых «матричных» растворов или запасных)

Растворы субстратов обычно заранее готовят по 10-20 мл в концентрации 500 мМ, навески приведены в Приложении 4, табл. 3.

Навески внести в 5 мл бидистиллированной воды и начать процедуру доведения $\mathrm{pH}$ до величины 7,0 $\pm 0,01$; в процессе доведения $\mathrm{pH}$ кислоты полностью растворяются.

Доведение $\mathrm{pH}$ растворов субстратов проводят с помощью фиксаналов или самостоятельно приготовленных $1 \mathrm{H}, 0,1 \mathrm{H}$ и 0,01 Н растворов КОН. При проведении данной процедуры необходимо учитывать, что в отсутствие буферной емкости водные растворы субстратов легко перетитровываются.

После добавления каждой капли необходимо дождаться стабилизации рН. 
По достижении $\mathrm{pH}$ раствора 6,0 аккуратно дотитровывают (удобно стеклянной палочкой) более разведенным раствором $0,1 \mathrm{H}$ КОН до величины 7,0-7,2. На этом этапе не требуется точное доведение $\mathrm{pH}$ до 7,2, так как в условиях отсутствия буферной емкости это сложно и грозит нежелательным перетитровыванием раствора.

Затем доводят раствор до конечного объема 10 мл.

Готовые субстраты разливают в пробирки эппендорф по 0,5-1 мл, которые 12 месяцев могут храниться в замороженном виде при $-20{ }^{\circ} \mathrm{C}$. Перед работой пробирку размораживают и добавляют нужное количество в основную среду инкубации в объеме 10 мкл/мл. Повторно замороженные и размороженные субстраты не используют.

Удобно разливать в эппендорфы ровно столько раствора, сколько понадобится для приготовления среды с небольшим запасом (у нас это 0,5-1 мл в зависимости от объема работы), при этом используется практически весь раствор и отходы минимизируются.

Все приготовленные пробы после использования утилизируются.

\section{4. Окрашивание ядер и хранение мазков}

Окрашивание ядер необходимо при процедуре микроскопирования для идентификации клеток.

Стекла помещают в кювету типа «Шиффердекер», заливают 0,05 \% раствором НК комнатной температуры на 8 мин. Затем промывают дистиллированной водой в течение 5-10 с и высушивают на воздухе.

Мазки после подсыхания при комнатной температуре готовы для микроскопирования. Микроскопирование можно проводить в течение 2-10 дней. Хранить мазки следует в темном месте при нормальной комнатной температуре $\left(18-23{ }^{\circ} \mathrm{C}\right)$.

\section{Раствор нейтрального красного для окрашивания ядер}

Используется 0,05 \% раствор НК, для чего 300 мг красителя растворяют в 600 мл бидистиллированной воды. Раствор хранится в стеклянной посуде с плотно закрытой крышкой в темноте в течение 3-6 месяцев.

5. Микроскопирование окрашенных мазков, работа с программой захвата изображений

Важно строго одинаково просматривать мазки под микроскопом.

Внимательно посмотреть на мазок крови, мысленно отступить около 7 мм от начальной капли крови и 10 мм от конца мазка; оставшуюся часть мысленно разделить на три равных зоны - начало, конец и середину (рис. 4). Капнуть каплю иммерсионного масла на участок ближе к середине зоны «Начало» (точка 1 на рис. 4) и набрать 100 лимфоцитов, двигаясь по траектории «меандра», как показано на рис. 4.

Необходимо фотографировать ВСЕ лимфоциты ПОДРЯД, не выбирая и не отдавая преимущества ярко окрашенным или более правильной формы, что отразит состав популяции. 


\section{Захват изображений с мазка}

Программа обсчета изображений работает с любыми изображениями формата jpg, важно лишь, чтобы на каждой фотографии присутствовала одна клетка. Поэтому захват изображений можно осуществлять любой удобной программой, позволяющей выбирать часть кадра для сохранения. Мы используем специально разработанную для этих целей программу Blood Runner (Россия, автор Игорь Соколовский).

Работа с программой захвата изображений Blood Runner вынесена в отдельную инструкцию (Приложение 6).

\section{6. Обработка изображений}

Обработка полученных изображений осуществляется специально разработанной программой Cell Composer (Свидетельство о государственной регистрации программы для ЭВМ № 2012618186 от 10. 09.2012).

Так как программа Cell Composer не работает с файлами предыдущей программы (тип brd), то все полученные файлы необходимо привести в формат jpg.

Для этого необходимо открыть программу Blood Runner и загрузить туда серию, готовую к обработке, для этого необходимо нажать кнопку «Загрузить серию» и в проводнике выбрать соответствующий файл формата brd. Откроются все снятые в этой серии изображения. Наведя мышкой на любое из них, нажать правую кнопку мышки и в открывшемся контекстном меню выбрать «Сохранить все как...», откроется окно проводника, где нужно выбрать папку для сохранения файлов, ввести имя серии с учетом того, что каждое изображение этой серии будет автоматически сохраняться в отдельный файл под своим номером, добавляемой программой автоматически к введенному имени серии; нажать кнопку «Сохранить». Каждый файл серии будет сохранен в формате jpg в отдельный файл в указанную папку. Файлы готовы для загрузки в программу обсчета Cell Composer.

Работа с Программой Cell Composer вынесена в отдельную инструкцию (Приложение 7). 


\section{ПОЛУЧЕННЫЕ РЕЗУЛЬТАТЫ}

В настоящей работе мы хотим обратить особое внимание на то, что для врача, который пожелает использовать предлагаемый инновационный способ диагностики состояния организма, главным преодолением должно быть освоение нового массива знаний о регуляции митохондрий в условиях организма.

Впервые исследования активности ферментов митохондрий связывают их с деятельностью общих физиологических систем регуляции, в частности с адренергической (АЭ) и холинэргической (ХЭ). Эти новые сведения об участии митохондрий в формировании физиологических ответов организма получены благодаря развитию метода исследования функций иммобилизованных в клетке митохондрий, гораздо лучше сохраняющего вне организма состояние исследуемых органелл в организме. Благодаря этому измерение нескольких биохимических показателей в митохондриях становится миниатюрным физиологическим обследованием организма.

Поэтому заинтересованным врачам для применения ЦБХ метода в клинических исследованиях, помимо технологической информации, необходимо овладеть информацией биохимии дополнительно к врачебной и преодолеть барьер ознакомления с новыми областями знаний. Однако мы надеемся, что расширение представлений о связи митохондриальных процессов с физиологическими и патологическими явлениями вознаградит ищущих врачей за их усилия и поможет повысить уровень понимания состояния конкретного больного и расширить возможности коррекции патологических сдвигов.

С целью облегчить этот важный этап освоения новой методологии мы включаем в Рекомендации разъяснения по трактовке результатов. Это тем более необходимо, что ЦБХ метод открывает новые биохимические феномены, которые не описаны в учебных руководствах.

Для биохимиков необходимы и разъяснения по физиологическим механизмам развития исследуемых заболеваний, с которых мы начнем.

\section{1. Патофизиологические механизмы (патогенгеза) развития БА и ХОБЛ}

В упрощенном виде патогенез бронхиальной астмы можно представить как комбинацию двух основополагающих механизмов: хронического воспаления дыхательных путей и гиперреактивности бронхов. Вследствие инициирования различными механизмами возникает хроническое воспаление дыхательных путей (отек, вазодилатация, клеточная инфильтрация, увели- 
чение слизистых желез и мышечной массы бронхов) и начинают высвобождаться медиаторы воспаления.

В основе механизмов гиперреактивности дыхательных путей лежит дисбаланс в вегетативной (автономной) нервной системе - повышение активности: холинергической нервной системы и альфа-адренорецепторов (что позволяет им доминировать, приводя к бронхоконстрикции) на фоне снижения активности адренергических бронходилататорных систем.

Механизм бронходилатации (расширения бронхов) реализуется двумя путями. Первый путь - это инактивация ацетилхолина ферментом холинэстеразой и прекращение его действия на гладкую мускулатуру. Если же в результате очень сильного раздражения выделяется большое количество ацетилхолина, то реализуется второй путь: избыток ацетилхолина стимулирует мозговой (внутренний) слой надпочечников. Это приводит к выбросу адреналина - вещества, оказывающего бронхорасширяющее действие путем расслабления спазмированных гладких мышц. Таким образом, защитный механизм бронхоспазма реализуется нервно-рефлекторным путем с помощью ацетилхолина, а механизм бронходилатации - гуморальным, с помощью адреналина. Между активностью этих механизмов существует определенный баланс, от которого и зависят степень сокращения и тонус бронхиальной мускулатуры. У некоторых здоровых субъектов нарушение этого баланса (в силу целого ряда причин) обусловливает повышенный бронхоспастический рефлекс на различные внешние раздражители (туман, холодный воздух) или форсированное (усиленное и учащенное) дыхание. Это явление носит название гиперреактивности бронхиального дерева. Повышенная реактивность - один из механизмов, способствующих развитию бронхиальной астмы. В том случае, если гиперреактивность выявляется у здорового человека, она носит название первичной и, по сути, является как бы индивидуальной особенностью этого субъекта.

\section{2. Функциональная значимость выявляемых ЦБХ.методом изменений} активности ферментов митохондрий и гликолиза

Отмеченная в П. 1 роль роль АЭ регуляции в патогенезе исследуемых заболеваний замечательно согласуется с независимой, давно опубликованной работой [21], показывающей противоположность дыхания МХ легких и почек.

Для легких характерно низкое дыхание и высокая генерация перекиси водорода, а отсюда высокая чувствительность к гипоксии. Для почек наоборот.

Согласно нашим данным АЭ регуляция активирует СДГ с опасностью гиперактивации, которая опасна сама по себе и переходом в ингибирование. Можно предположить, что гиперактивация СДГ, которая выявляется ЦБХ методом у больных БА и ХОБЛ, является неблагоприятным показателем. Она, как будет показано, связана со снижением ЭФВ. По ЭФВ особенно удобно следить за значимостью митохондриального дыхания, более чувствительно, чем по ЛДГ и СДГ. 
В исследованиях на кроликах, которые по симпатическо-парасимпатической регуляции ближе к человеку, чем крысы и мыши, а также в исследованиях на детях с лейкозами, нормальным ростом разной интенсивности в разном возрасте, а также у детей, больных миопатией, нами показано, что предложенный показатель ЭФВ, определяемый как отношение ЛД/ СДГ, очень чувствительно определяет не только злокачественный рост с большой амплитудой, но и малые отличия интенсивности роста, в том числе это могут быть восстановительные биосинтетические процессы, которые лежат в основе биологической устойчивости клеток и организма.

Проведенные исследования можно разделить на два этапа.

\section{1 эman}

Под динамическим наблюдением в течение 12 месяцев находились 74 пациента (м. - 44 и ж. - 30) с верифицированным диагнозом АБА, среднетяжелой, персистирующей. В течение последнего года все больные сохраняли хороший контроль над симптомами АБА на фоне терапии ДДБА/ ИГКС. До назначения ДДБА/ИГКС приступы удушья были до 3-4 раз в месяц; базисная терапия проводилась нерегулярно, чаще гормонами и монотерапией иГКС. Отмечалось снижение переносимости физических нагрузок. Объем форсированного выдоха $64,9 \pm 11,6$ \% D. Суточная вариация пиковой скорости $27,9 \pm 8,1$. Приступы купировались бронхолитиками (в ингаляциях), по показаниям назначались глюкокортикостероиды парентерально. Сопутствующие аллергические заболевания регистрировались у 53 пациентов (71,6 \%). Сенсибилизация к бытовым аллергенам - у 22 (29,7 \%) больных, к пыльцевым - у 19 (25,7 \%) и грибковым аллергенам - у 11 (14,8 \%) пациентов. Средний возраст - 44,2 \pm 6,2 г. (16-72). По длительности заболевания больные распределились следующим образом: до 5 лет - 6 больных $(8,1)$, 5-10 лет - 18 больных (24,3 \%), 11-15 лет - 34 больных (45,9\%), свыше 15 лет - 16 больных (21,6 \%). Из общего числа больных курящих было 37 человек (70,2 \%), м. - 26 (59,4 \%), ж. - 11 (29,8 \%). Индекс массы тела $34,2 \pm 8,2$ (18,6-39,7). Пациенты 1 гр. (п = 38) получали салметерол/флютиказона пропионат (С/ФП) в режиме гибкого дозирования и 2 гр. (п = 36) форматерол/будесонид (Ф/БД) - в режиме постоянного дозирования. При обострении разрешалось пользоваться бета-2-агонистами короткого действия. Обострения на фоне лечения ДДБА/ИГКС отсутствовали, отсутствовали также ночные симптомы АБА, регистрировались только редкие приступы в дневное время (менее 2 за неделю), которые быстро купировались $\beta 2$-агонистами короткого действия.

На фоне терапии С/ФП наблюдалось повышение активности СДГ $(\mathrm{p}<0,05)$ и они были выше по сравнению с остальными группами (Приложение 8, рис. 3). В группе пациентов с базисной терапией Ф/БД активность СДГ превышала значения контрольной группы $(\mathrm{p}>0,02)$, но были ниже, чем в группе С/ФП. Активность фермента гликолиза была выше у пациентов 2 гр. 
Через 2 месяца отмечено постепенное снижение активности СДГ в 1 гр. и снижение активности ЛДГ во всех группах, что указывало на более глубокие нарушения энергетического обмена. Режим дозирования также влиял на активность митохондриальных ферментов и у пациентов 2 гр., но эти нарушения были менее выражены. При анализе показателей активности митохондриального фермента СДГ и фермента гликолиза - ЛДГ у пациентов АБА в зависимости от длительности заболевания было установлено, что у пациентов с длительностью аллергического воспаления до 10 лет, независимо от проводимой терапии, уже выявлялись нарушения их активности: средние значения активности СДГ составили $1,7 \pm 0,28$ и одновременно самые высокие значения ЛДГ - 11,6 $\pm 2,1(\mathrm{p}<0,05)$.

В контрольной группе СДГ $-1,1 \pm 0,14$ и ЛДГ $-8,9 \pm 1,2(\mathrm{p}<0,05)$. Такие значения всегда настораживают, так как высок риск, когда активация может перейти в гиперактивацию и в дальнейшем в ингибирование, что и наблюдалось у пациентов, имеющих длительность аллергического воспаления более 10 лет. Была выявлена значительная активация дыхания (активность СДГ) со снижением гликолиза (активность ЛДГ), которое может отражать ослабление восстановительных биосинтетических процессов. Такая активация СДГ, а следовательно, и активация адренергической системы может быть следствием более выраженной гипоксии.

Эффрект Варбурга у пацичентов с БА

В группе пациентов с базисной терапией $\mathrm{C} / Ф П$ отношение ЛДГ/СДГ ЭФВ был снижен по сравнению с остальными группами. Мы проанализировали это соотношение индивидуально у пациентов первой группы. Активность дегидрогеназ не позволяла различать небольшую разницу между пожилыми людьми с БА и контрольной группой. Но по ЭФВ позволял увидеть небольшие отличия более четко (Приложение 9, рис. 4).

В соответствии с ЭФВ статус первых двух пациентов лучше, так как ближе к норме и улучшается при повторном исследовании. Состояние трех последних пациентов хуже, так как ЭФВ у них ниже нормы и становится еще ниже для последних двух при повторном исследовании. Распределение пациентов по ЭФВ полностью соответствует мнению врача, основанному на клинических данных.

\section{2 эman}

В 2016 г. было проведено обследование 20 пациентов с диагнозами АБА и ХОБЛ.

Полученные данные представлены на рис. 4 Приложения 10. Данные выстроены в порядке увеличения ЭФВ. В целом для всей этой группы были характерны крайне низкие значения ЭФВ $(1,1 \div 4,0)$, что значительно ниже зоны нормы. Активность СДГ повышена по сравнению со здоровыми людьми - у кого незначительно, у кого - очень сильно: минимальное значение СДГ - 1,3 максимальное - 3,1. Активность ЛДГ у части пациентов была 
крайне низкой $(1,9-5)$, у остальных находилась в зоне нормы, но ни у кого значения нормы $(\sim 7 \div 11)$ не превышала.

Для динамического наблюдения в 2017 г. были выбраны 10 человек: в первую очередь пациенты с самым низким значением ЭФВ (П16, 1, 17, 11), 3 человека - со средними для данной группы значениями ЭФВ, но имеющие наиболее высокую активность ЛДГ (П10, 20 и П3) и 3 пациента, имеющих наибольшие в данной группе значения ЭФВ (П12, 5 и 15).

Эти пациенты были обследованы еще три раза - ноябрь 2016, март 2017 и июль 2017.

В результате анализа полученных данных выяснилось, что пациентов можно разделить на две группы - Группа 1 с исходно крайне низкой активностью ЛДГ $(1,9 \div 3,9)$, среднее значение $-2,7 \pm 0,8$, и Группа 2 с нормальной активностью ЛДГ $(7,0 \div 8,7)$, среднее значение $7,6 \pm 0,7$. Отличия по активности ЛДГ между этими группами статистически достоверны с очень высокой степенью $\mathrm{p}<0,000002$.

В группу 1 вошли пациенты № $1,11,12,16,17$; в группу 2 - № $3,5,10$, 15,20 . Полученные данные для каждого пациента представлены на рис. 6 Приложения 11.

На рис. 7 Приложения 12 представлены средние показатели по группам активности СДГ, ЛДГ и ЭФВ. Как уже говорилось, для пациентов группы 1 характерна также более низная по сравнению с группой 2 активность СДГ $(1,3 \div 2,0$ - в группе 1 и $1,8 \div 3,1$ - в группе 2$)$. Средняя активность СДГ по первой группе составляет 1,6, немного превышая нижнюю границу зоны нормы, в то время как средняя активность второй группы значительно превышала норму и составляла в среднем 2,7 у.е. Различия в активности СДГ между двумя группами также статистически достоверны.

Эффект Варбурга, характеризующий соотношение гликолиза и дыхания, в группе 1 крайне низкий - среднее значение - 1,7 у.е. за счет крайне низкой активности ЛДГ, т.е. сниженного гликолиза. Во второй группе этот показатель выше - 3,0, но также находится в диапазоне гораздо ниже нормы, но в этом случае это происходит за счет гиперактивной СДГ. Различия также статистически достоверны.

Следующее обследование было проведено осенью 2016 г. - через 5 месяцев после первого.

Изменения наблюдаемых активностей во времени и с течением лечения в обеих группах во многом были сходны: так, при повторном обследовании для обеих групп было характерно значительное увеличение активности ЛДГ, средние значения в первой группе уже составили 12,6 у.е (470 \% от исходного значения), а во второй группе - 16,8 (220\% от исходного значения). Эти показатели гликолиза уже (значительно - во второй группе) превышают значения, характерные для нормы. Активность СДГ в первой группе увеличилась в среднем до 2,4 у.е, приблизившись к повышенным значениям, 
характерным для второй группы, в то время как активность СДГ во второй группе практически не изменилась. За счет увеличения интенсивности гликолиза в обеих группах увеличился и эффект Варбурга - до 5,6 в первой группе, до 6,7 - во второй группе. Таким образом, повторное обследование выявило гиперактивацию как гликолиза, так и митохондриального дыхания в обеих группах. Возможно, это связано с наступлением холодного сезона и обострениями у пациентов.

Следующее обследование через 4-5 месяцев, проведенное весной 2017 г., выявило снижение опасно повышенных значений ЛДГ в обеих группах, приблизив их к верхней границе зоны нормы и также снижение гиперактивных показателей СДГ, приблизив значения каждой группы друг к другу.

Последнее обследование через 4 месяца в июле 2017 г. выявило продолжение снижения показателей гликолиза и дыхания в обеих группах и переход их в зону нормы: средняя активность СДГ в первой группе составила 1,1 у.е, ЛДГ - 8,7 у.е; во второй - 1, 0 и 7,1 соответственно. ЭФВ также пришел в зону нормы, составив 8,4 и 7,3 в двух группах соответственно.

Анализ полученных данных для пяти «нативных» пациентов с впервые выявленным диагнозом БА и ХОБЛ с повторным обследованием через 2,5-3 месяца после начала лечения.

Также дополнительно были обследованы пять человек, впервые обратившиеся к врачу и не получавшие лечения.

У четырех пациентов из пяти первично наблюдалась гиперактивная СДГ - от 1,5 до 2,6 (рис. 4), сопровождающаяся и гиперактивацией ЛДГ (11-13). Лишь у одного пациента (№ 26) значения и СДГ, и ЛДГ находились в норме (1,0 и 8,1 соответственно). ЭФВ был у всех снижен $(4,3-6,1)$, за исключением пациента № 26, у которого он так же, как и остальные показатели находился в норме. Средние значения всех показателей приведены на рис. 8 Приложения 13.

В результате трех месяцев лечения, у всех пациентов произошло снижение гиперактивной СДГ до показателей, характерных для нормы и даже чуть ниже (средние значения - 0,9). ЛДГ у двух пациентов, имеющих исходно высокие ее значения снизилась (пациенты № 22 и 25), у пациента с исходно нормальным значением ЛДГ (№ 24), ее активность повысилась, и у оставшихся двух пациентов активность ЛДГ практически не изменилась.

При этом у всех пациентов показатели ЭФВ выросли: до нормы упациентов № 22, 23, 25 и значительно выше нормы - у пациента № 24.

Таким образом, исходя из полученных данных, можно сделать вывод, что снижение исходно гиперактивной СДГ практически у всех пациентов в результате лечения можно считать благоприятным признаком успешного лечения. Это сопровождается нормализацией процессов гликолиза, отвечающего за поддержание восстановительных процессов. Их соотношение ЭФВ также пришел в зону нормы у большинства пациентов (рис. 9 Приложения 14). 


\section{ТЕХНОЛОГИЯ ВНЕДРЕНИЯ ПОЛУЧЕННЫХ РЕЗУЛЬТАТОВ}

Результаты исследования позволили разработать технологию персонализированного подхода к назначению метаболической терапии при заболеваниях сердечно-сосудистой системы, болезней органов дыхания, при эндокринной патологии и других патологических процессах, связанных с гипоксией, и когда в патогенезе заболевания ведущая роль принадлежит окислительному стрессу. При выявлении значительной активации дыхания (активность СДГ) со снижением гликолиза (активность ЛДГ) указывает на ослабление восстановительных биосинтетических процессов. Такая активация СДГ, а следовательно, и активация адренергической системы может быть следствием более выраженной гипоксии и требует назначения активной антиоксидантной терапии. При гиперактивности митохондриальных ферментов назначение антиоксидантной терапии опасно переходом повышенной активности в стагнацию и более выраженной гипоксией тканей. Такие пациенты нуждались в активной детоксикационной терапии с последующим назначением антиоксидантов. Технология постановки ЦБХ анализа проста и может широко использоваться в клинико-диагностических лабораториях практического здравоохранения для персонализированного подхода к назначению антиоксидантной терапии. 


\section{ЗАКЛЮЧЕНИЕ}

\section{1. Особенности проявления активности СДГ, ЛДГ и ЭФВ у больных, страдающих респираторными патологиями}

Наши исследования впервые показали отличия проявления активности СДГ и ЛДГ, сопряженные друг с другом, и их отношения - ЭФВ у обследованных групп больных от описанных в литературе результатов, полученных на интенсивно растущих раковых клетках, в сравнении с нормальной тканью.

Они также отличаются от наших предшествующих исследований на лимфоцитах детей, больных лейкозами, здоровых детей разного возраста, детей, больных миопатиями, а также от данных на кроликах разного возраста и при нескольких возбуждающих воздействиях.

Привычным из литературы является представление о сильном возрастании аэробного гликолиза - ЛДГ, и снижении активности дыхания митохондрий - СДГ при интенсивном раковом росте. У обследованных нами больных выявлены противоположные изменения.

Для них в исходном состоянии характерна, напротив, гиперактивность СДГ сниженная или близкая к норме активность ЛДГ, и за счет обеих этих составляющих необычное снижение ЭФВ по сравнению со здоровой нормой для сходного возраста.

У этих больных впервые выявлено повышение ЭФВ при лечении, причем за счет уменьшения гиперактивности СДГ без превышения ЛДГ уровня нормы. Результаты по всем группам сходны. Особенно ярко они проявляются на группе «нативных» больных, не получающих лечения до начала обследования

2. Соответствие сопряженных изменений СДГ, ЛДГ и ЭФВ с заключением о тяжести состояния больных по клиническим данным

Персонифицированное распределение индивидуумов по степени отклонения от нормы соответствовало тяжести состояния независимо по ЦБХ данным и по клиническим характеристикам.

Таким образом, митохондриальные ферменты лимфоцитов отражают снижение энергетического обмена у пациентов АБА, а соотношение ЛДГ/ СДГ оказалось более чувствительным показателем изменений энергетического обмена. Кроме того, активность СДГ и соотношение ЛДГ/СДГ зависели от режима дозирования и длительности аллергического воспаления.

Отношение ЛДГ/СДГ может стать интегральным и чувствительным показателем энергетического обмена, который изменяется даже при незначительном повышении активности СДГ. 
Важным преимуществом ЦБХ показателей является то, что на их основе можно сделать четкие выводы о тяжести состояния, просто основанные на величине показателя.

Использование разработанного чувствительного метода комплексной оценки функционального состояния организма в клинической практике расширит возможности применения результатов фундаментальных исследований в области медицины и физиологии.

Клинико-биохимические лаборатории смогут по критериям, полученным ЦБХ методом (активность СДГ, ЛДГ, их соотношение), выявлять митохондриальные нарушения на ранних стадиях развития заболевания.

Расширение представлений о связи митохондриальных процессов с физиологическими и патологическими явлениями позволит врачам повысить уровень понимания состояния конкретного больного и расширить возможности коррекции патологических сдвигов.

\section{Конфликт интересов}

Конфликт интересов авторами не заявлен.

Работа выполнена в рамках госзадания на 2015-2017 гг.

Регистрационный номер АААА-А17-117051210058-7.

Тема 0479-2017-0002: «Исследование клеток крови и митохондриальных ферментов для ранней диагностики и коррекции патологии энергетического обмена». 


\title{
СПИСОК СОКРАЩЕНИЙ
}

\author{
ЦБХ - цитобиохимический \\ МX - митохондрии \\ ЭФВ - эффект Варбурга \\ ОФ - окислительное фосфорилирование \\ ЯНТ - янтарная кислота \\ ЛАК - молочная кислота, лактат \\ СДГ - сукцинатдегидрогеназа \\ ЛДГ - лактатдегидрогеназа \\ АБА - атопическая бронхиальная астма \\ ХОБЛ - хроническая обструктивная болезнь легких \\ НСТ - нитросиний тетразолий \\ НК - нейтральный красный \\ СИ - среда инкубации
}




\section{СВЕДЕНИЯ ОБ АВТОРАХ}

Косякова Нинель Ивановна - доктор медицинских наук, зам. главного врача по науке, зав. отделением иммунологии и аллергологии БПНЦ РАН;

Сандалова Татьяна Владимировна - врач-терапевт дневного стационара БПНЦ РАН;

Шибаев Николай Викторович - кандидат медицинских наук, зав. отдедением функциональной диагностики БПНЦ РАН;

Панкратова Елена Витальевна - зав. клинико-биохимической лабораторией БПНЦ РАН;

Кондрашова Мария Николаевна - доктор биологических наук, профессор, заслуженный работник науки, главный научный сотрудник ФГБУН Института теоретической и экспериментальной биофизики РАН;

Захарченко Марина Владимировна - кандидат биологических наук, научный сотрудник ФГБУН ИТЭБ РАН. 


\section{ПЕРЕЧЕНЬ ОПУБЛИКОВАННЫХ РАБОТ, ВЫСТУПЛЕНИЙ, НАЛИЧИЕ ПАТЕНТА ПО ТЕМЕ МЕТОДИЧЕСКИХ РЕКОМЕНДАЦИЙ ЗА ПОСЛЕДНИЕ ТРИ ГОДА (2015-2017 ГГ.)}

1. Кондрашова М.Н., Хундерякова Н.В., Захарченко М.В., Ячкула Т.В., Плясунова С.А., Сухоруков В.С., Косякова Н.И., Литвинова Е.Г., Федотчева Н.И., Шварцбурд П.М. Метод определения функционального состояния митохондрий в организме у человека по показателям активности ферментов и микроскопическому виду клеток // Медицинский алфавит. Современная лаборатория. 2016. Т. 3. № 19 (282). C. 83-85.

2. Захарченко М.В., Косякова Н.И., Кондрашова М.Н. Исследование ферментов энергетического обмена в лимфоцитах у пациентов с бронхиальной астмой с целью выбора средств лекарственной коррекции метаболизма // Гематология и трансфузиология. 2016. Т. 61. (1, Приложение 1). С. 118.

3. Кондрашова М.Н., Захарченко М.В., Хундерякова Н.В., Ковзан А.В., Ячкула Т.В., Литвинова Е.Г., Шварцбурд П.М., Федотчева Н.И. Субстраты окисления янтарная и $\alpha$-кетоглутаровая кислоты являются синергистами гормонов адреналина и ацетилхолина в системе симпатической и парасимпатической регуляции метаболизма. Научные труды V Съезда биохимиков России // ACTA NATURAE. Спецвыпуск. 2016. Т. 2. С. 54-55.

4. Хундерякова Н.В., Литвинова Е.Г., Ячкула Т.В., Захарченко М.В., Ковзан А.В., Федотчева Н.И., Шварцбурд П.М., Плясунова С.А., Кондрашова М.Н. Определение цитобиохимическим методом активности сукцинатдегидрогеназы и лактатдегидрогеназы в лимфоцитах крови при остром лимфолейкозе. Научные труды V Съезда биохимиков России // ACTA NATURAE. Спецвыпуск. 2016. T. 2. C. 58.

5. Федотчева Н.И., Литвинова Е.Г., Захарченко М.В., Хундерякова Н.В., Фадеев Р.С., Теплова В.В., Федотчева Т.А., Белобородова Н.В., Кондрашова М.Н. Свойства и преимущества солей тетразолия как акцепторов для измерения активности редокс-зависимых ферментов в изолированных митохондриях, тканях и лейкоцитах. Научные труды V Съезда биохимиков России // ACTA NATURAE. Спецвыпуск. 2016. Т. 2. С. 57.

6. Khunderyakova N.V., Yachkula T.V., Zakharchenko M.V., Plyasunova S.A., Sukhorukov V.S., Baranich, N.I., Litvinova E.G., Fedotcheva N.I., Schwartsburd P.M., Kondrashova M.N. Cytobiochemical biomarkers of the state of mitochondria in humans. I. Great differences in children suffering from leukemia or myopathy as compared with healthy children of similar age". The 7th World Congress on Targeting Mitochondria 2016. Berlin // Journal World Mitochondria Society. 2016. V. 2 (2). P. 118. 
7. Zakharchenko M.V., Kosyakova N.I., Khunderyakova N.V., Litvinova E.G., Fedotcheva N.I., Schwartsburd P.M., Kondrashova M.N. Cytobiochemical biomarkers of the state of mitochondria in humans. II. Small but clear differences between elderly people with bronchial asthma and these with no clinical symptoms or middle-aged examinees. The 7th World Congress on Targeting Mitochondria 2016. Berlin // Journal World Mitochondria Society. 2016. V. 2 (2). P. 171.

8. Федотчева Н.И., Литвинова Е.Г., Захарченко М.В., Хундерякова Н.В., Фадеев Р.С., Теплова В.В., Федотчева Т.А., Белобородова Н.В., Кондрашова М.Н. Субстрат-специфичное восстановление солей тетразолия в изолированных митохондриях, тканях и лейкоцитах // Биохимия. 2017. Т. 82. Вып. 2. С. 309-322.

9. Захарченко М.В., Хундерякова Н.В., Ячкула Т.В., Фадеев Р.С., Акатов В.С., Литвинова Е.Г., Федотчева Н.И., Шварцбурд П.М., Кондрашова М.Н. $\alpha$ - Кетоглутаратдегидрогеназа (КДГ) как мишень холинэргической регуляции в митохондриях. Активация КДГ ацетилхолином для ее выявления в клетках на мазке. Рецепторы и внутриклеточная сигнализация. Сборник статей. Т. 1 / под ред. В.П. Зинченко и А.В. Бережнова. Пущино: Цифровая типография Fix-Print, 2017. C. 604-611.

\section{Результаты представлены на конференциях:}

1. III Конгресс гематологов России. 14-16 апреля, Москва.

2. Юбилейный XX форум «Национальные дни лабораторной медицины России - 2016». Общероссийская междисциплинарная научно-практическая конференция с международным участием «Консолидация лабораторной медицины и клинической практики: диагностические инновации, лабораторная индустрия». Москва, 14-16 сентября 2016.

3. 7-th World Congress on Targeting Mitochondria. Berlin - Germany. October 24-26, 2016.

4. Ежегодная научно-практическая конференция БПНЦ РАН. 


\section{СПИСОК ЛИТЕРАТУРЫ}

1. Кондрашова М.Н. Гормоноподобное действие янтарной кислоты // Вопр. биол. мед. фармац. химии. 2002. Т. 1. С. 7-12.

2. Кондрашова М.Н. и др. Субстратно-гормональная система регуляции физиологического состояния. Условия ее выявления. Использование в практике. Горизонты биофизики. Пущино: ОНТИ НЦБИ, 2003. С. 147-154.

3. Кондрашова М.Н. Янтарная кислота в медицине, пищевой промышленности, сельском хозяйстве. Пущино: ОНТИ, 1997.

4. Кондрашова М.Н. Митохондрии в патологии. Пущино: ОНТИ, 2001.

5. Kondrashova M.N., Zakharchenko M.V. et al. // Study of Succinate Dehydrogenase and $\alpha$-Ketoglutarate Dehydrogenase in Mitochondria inside Glass-Adhered Lymphocytes under Physiological Conditions. The Two Dehydrogenases as Counterparts of Adrenaline and Acetylcholine Regulation. in: Dehydrogenases. Ed. by. Canuto R.A. InTech, Italy Turin. 2012. P. 235-257.

6. Кондрашова М.Н., Захарченко М.В., Хундерякова Н.В., Маевский Е.И. Патент Российской Федерации. Цитобиохимический способ определения активности сукцинатдегидрогеназы, окисления эндогенной янтарной кислоты, сигнального действия микромолярных концентраций янтарной кислоты, его применение для количественной оценки уровня адренергической регуляции в организме, среда и набор для осуществления способа. Приоритет от 20.11.2007. Опубликовано: 20.08.09 Бюллетень Роспатента № 23.

7. Кондрашова М.Н. Структурно-кинетическая организация цикла трикарбоновых кислот при активном функционировании ткани // Биофизика. 1989. Т. 34. № 3. C. $450-458$.

8. Kondrashova M.N., Zakharchenko M.V. and Khunderyakova N.V. Preservation of the in vivo state of mitochondrial network for ex vivo physiological study of mitochondria // Int J Biochem Cell Biol. 2009. Vol. 41. P. 2036-2051.

9. Zakharchenko M.V., Temnov A.V., Kondrashova M.N. Effect of carnosine on selforganization of mitochondrial assemblies in rat liver homogenate // Biochemistry. 2003. № 68. P. 1002-1005.

10. Temnov A.V., Sirota T.V., Fedotcheva N.I., Saakyan I.R., Venediktova N.A., Kondrashova M.N. Responses of mitochondria keeping blocks of structure network // Eur J Med Res. 2000. № 5. P. 30.

11. Kondrashova M.N., Sirota T.V., Temnov A.V., Belousova Zh.V., Petrunyaka V.V. Reversible organization of mitochondria into associations as a factor regulating respiration // Biochemistry. 1997. № 62. P. 129-137.

12. Kondrashova M.N., Fedotcheva N.I., Saakyan I.R., Sirota T.V., Lyamzaev K.G., Kulikova M.V., Temnov A.V. Preservation of native properties of mitochondria in rat liver homogenate // Mitochondrion. 2001. № 1. P. 249-267. 
13. Rossignol R. and Karbovsky M. Editorial of the directed issue on mitochondrial dynamics in biology and medicine // Int J Biochem Cell Biol. 2009. № 41. P. 1748-1749.

14. Jastroch M., Morin S., Tschöp M.H. The hypothalamic neural - glial network and the metabolic syndrome // Clin Endocrin \&Metab. V. 28 (5). P. 661-671.

15. Zakharchenko M.V., Zakharchenko A.V., Khunderyakova N.V., Tutukina M.N., Simonova M.A., Vasilieva A.A., Romanova O.I., Fedotcheva N.I., Litvinova E.G., Maevsky E.I., Zinchenko V.P., Berezhnov A.V., Morgunov I.G., Gulayev A.A., Kondrashova M.N. Burst of succinate dehydrogenase and $\alpha$-ketoglutarate dehydrogenase activity in concert with the expression of genes coding for respiratory chain proteins underlies short-term beneficial physiological stress in mitochondria // The International Journal of Biochemistry \& Cell Biology. 2013. V. 45 (1). P. 190-200.

16. Krauss S., Brand M.D., Buttgereit F. Signaling takes a breath - new quantitative perspectives on bioenergetics and signal transduction // Immunity. 2001. Vol. 15. P. 497-502.

17. Gerriets V.A. and Rathmell J.C. Metabolic pathways in T cell fate and function // Trends Immunol. 2012. Vol. 33. P. 168-173.

18. Macintyre A.N., Rathmell J.C. Activated lymphocytes as ametabolic model for carcinogenesis // Cancer Metab. 2013. Vol. 1. P. 5.

19. Pearce E.L. and Pearce E.J. Metabolic Pathways in Immune Cell Activation and Quiescence // Immunity. 2013. Vol. 38. P. 633-643.

20. Gerritje J.W. van der Wind and Pearce E.L. Metabolic switching and fuel choice during T-cell differentiation and memory development // Immunological Reviews. 2012. Vol. 249. P. 27-42.

21. Michelakis E.D., Hampl V. et al. Diversity in Mitochondrial Function Explains Differences in Vascular Oxygen Sensing // Circ. Res. 2002. V. 90. P. 1307-1315. 


\section{ПРИЛОЖЕНИЕ № 1}

Таблица 1

Необходимые реактивы

\begin{tabular}{|c|c|c|c|c|}
\hline \multicolumn{2}{|c|}{ Название pyc/engl } & \multirow{2}{*}{$\begin{array}{l}\text { MW } \\
74,55\end{array}$} & \multirow{2}{*}{$\begin{array}{c}\text { Фирма- } \\
\text { изготовитель } \\
\text { Sigma-Aldrich }\end{array}$} & \multirow{2}{*}{$\begin{array}{c}\text { Кат. номер } \\
\text { Р3911 }\end{array}$} \\
\hline Хлорид калия & Potassium chloride & & & \\
\hline Хепес & HEPES & 238,3 & Sigma-Aldrich & H3375 \\
\hline Янтарная кислота & Succinic acid & 118,09 & Sigma-Aldrich & S7501 \\
\hline Молочная кислота & L-(+)-Lactic acid & 90,08 & Sigma-Aldrich & L1750 \\
\hline \multirow{2}{*}{$\begin{array}{c}\text { Нитросиний } \\
\text { тетразолий-п } \\
\text { (хлорид) (НСТ) }\end{array}$} & \multirow{2}{*}{$\begin{array}{l}\text { Nitrotetrazolium } \\
\text { Blue chloride }\end{array}$} & 817,64 & $\begin{array}{c}\text { AppliChem, } \\
\text { США (в Dia-m) }\end{array}$ & D298839 \\
\hline & & 817,64 & Sigma-Aldrich & N6876 \\
\hline \multirow[t]{2}{*}{ НАД } & \multirow{2}{*}{$\begin{array}{c}\beta \text {-Nicotinamide } \\
\text { adenine dinucleotide } \\
\text { sodium salt }\end{array}$} & 663,43 & $\begin{array}{c}\text { AppliChem, } \\
\text { США (в Dia-m) }\end{array}$ & A-1124,0025ф \\
\hline & & 685,41 & Sigma-Aldrich & N0632 \\
\hline $\begin{array}{c}\text { Ацетон } \\
\text { (диметилкетон), } \\
\text { ОСЧ }\end{array}$ & Acetone & & $\begin{array}{l}\text { Реахим,3АО «База } \\
\text { № } 1 \text { Химреактивов }\end{array} \mid$ & \\
\hline $\begin{array}{c}\text { Нейтральный } \\
\text { красный инд. } \\
\text { (ЧДА) }\end{array}$ & Neutral Red & 288,78 & Диа - М Россия & S553242.0100 \\
\hline $\begin{array}{c}\text { Гидрокси́д ка́лия } \\
\text { (для доведения } \mathrm{pH} \text { ) }\end{array}$ & Potassium hydroxide & 56,1056 & Sigma-Aldrich & 484016 \\
\hline $\begin{array}{c}\text { Буферные } \\
\text { стандарт-титры }\end{array}$ & & & Mettler Toledo & \\
\hline $\begin{array}{c}\text { Бидистиллирован- } \\
\text { ная вода }\end{array}$ & & & & \\
\hline
\end{tabular}




\section{ПРИЛОЖЕНИЕ № 2}

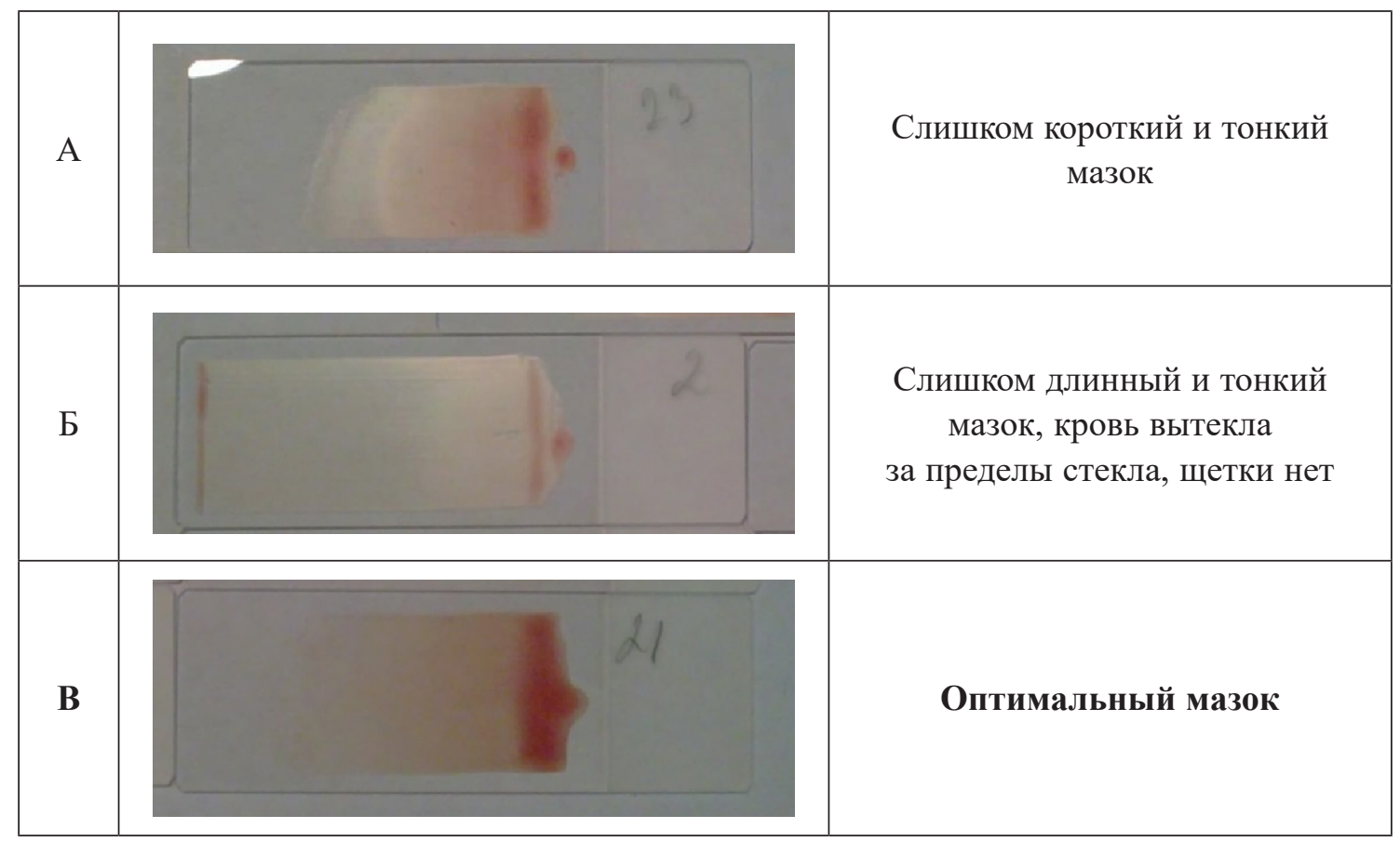

Рис. 1. Приготовление мазка крови 


\section{ПРИЛОЖЕНИЕ № 3}

Таблица 2

Навески веществ для приготовления среды инкубации

\begin{tabular}{|l|c|c|c|c|c|c|c|}
\hline Бидист. вода, мл & 40 & 50 & 100 & 150 & 250 & 300 & 350 \\
\hline KCl, г & 0,372 & 0,47 & 0,93 & 1,39 & 2,32 & 2,79 & 3,26 \\
\hline Hepes, г & 0,095 & 0,12 & 0,238 & 0,357 & 0,594 & 0,713 & 0,81 \\
\hline НСТ, мг & 40 & 50 & 100 & 150 & 250 & 300 & 350 \\
\hline
\end{tabular}




\section{ПРИЛОЖЕНИЕ № 4}

Таблица 3

Навески субстратов для приготовления матричных растворов

\begin{tabular}{|c|c|c|c|c|c|}
\hline \multirow{2}{*}{ Субстрат } & \multirow{2}{*}{ MW } & \multirow{2}{*}{$\begin{array}{c}\text { Раствор, } \\
\text { молярность }\end{array}$} & \multicolumn{2}{|c|}{ Навеска для приготовления Х мл } \\
\cline { 4 - 6 } & & 1 мл & 10 мл & 20 мл \\
\hline ЯНТ & 118,09 & $500 \mathrm{мM}$ & 59,04 мг & 590 мг & 1,18 г \\
\hline ЛАК & 90,08 & $500 \mathrm{MM}$ & 45,04 мг & 450 мг & 0,9 г \\
\hline
\end{tabular}




\section{ПРИЛОЖЕНИЕ № 5}

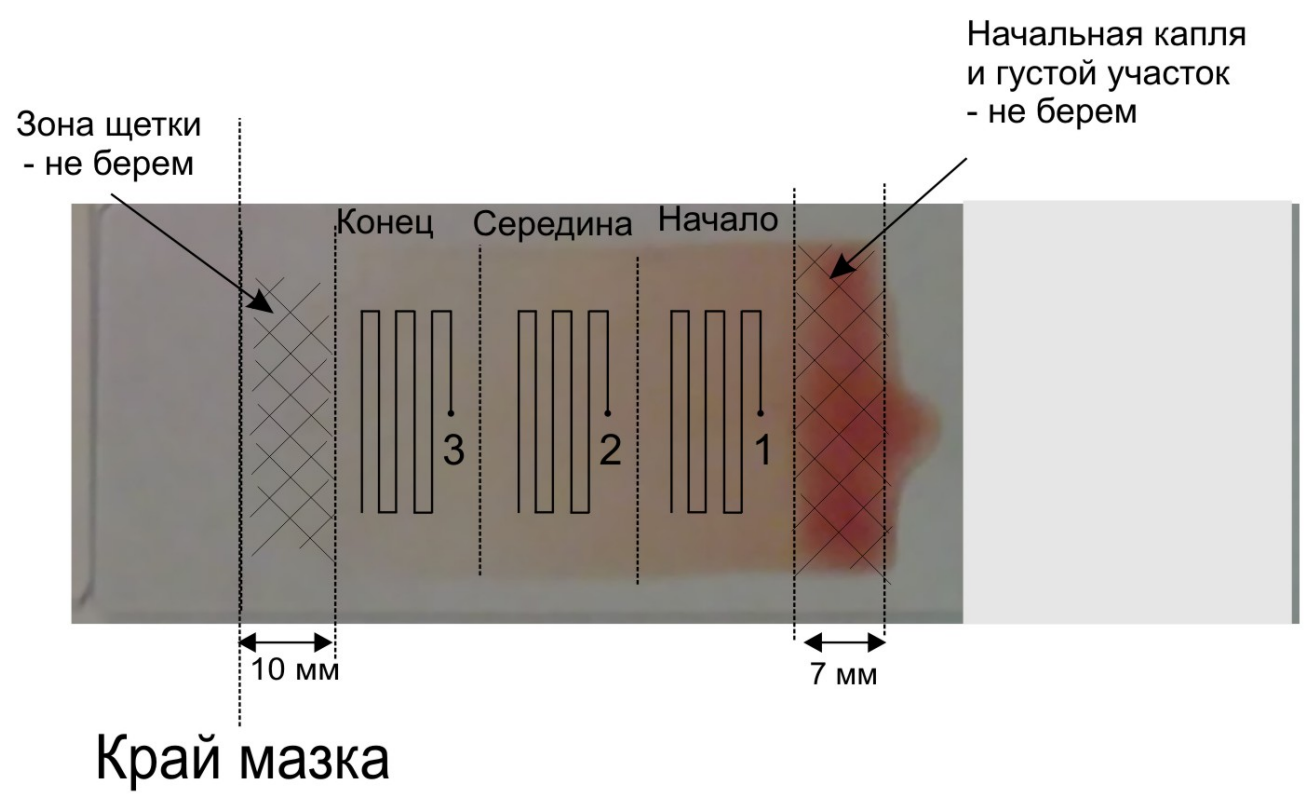

Рис. 2. Траектория просмотра мазка крови под микроскопом 


\section{ПРИЛОЖЕНИЕ № 6}

\section{Инструкция по работе с программой захвата изображений Blood Runner}

1. Перед началом работы необходимо мазок крови, зафиксированный и окрашенный в соответствии с ЦБХ методом, поместить на предметный столик микроскопа (для съемки используется масляная иммерсия, объектив х90). Глядя в окуляры микроскопа, поймать в поле зрения клетки крови, навести на резкость и выбрать первый объект для съемки. Видеокамера, смонтированная на микроскоп, должна быть уже подключена к компьютеру, настроена и сфокусирована на мазок крови.

2. Открыть окно программы, два раза щелкнув мышкой на значке программы. Откроется окно (рис. 1). Перед началом работы удобно развернуть окно программы на весь экран, нажав среднюю кнопку с окошком в левом верхнем углу (см. стрелку).

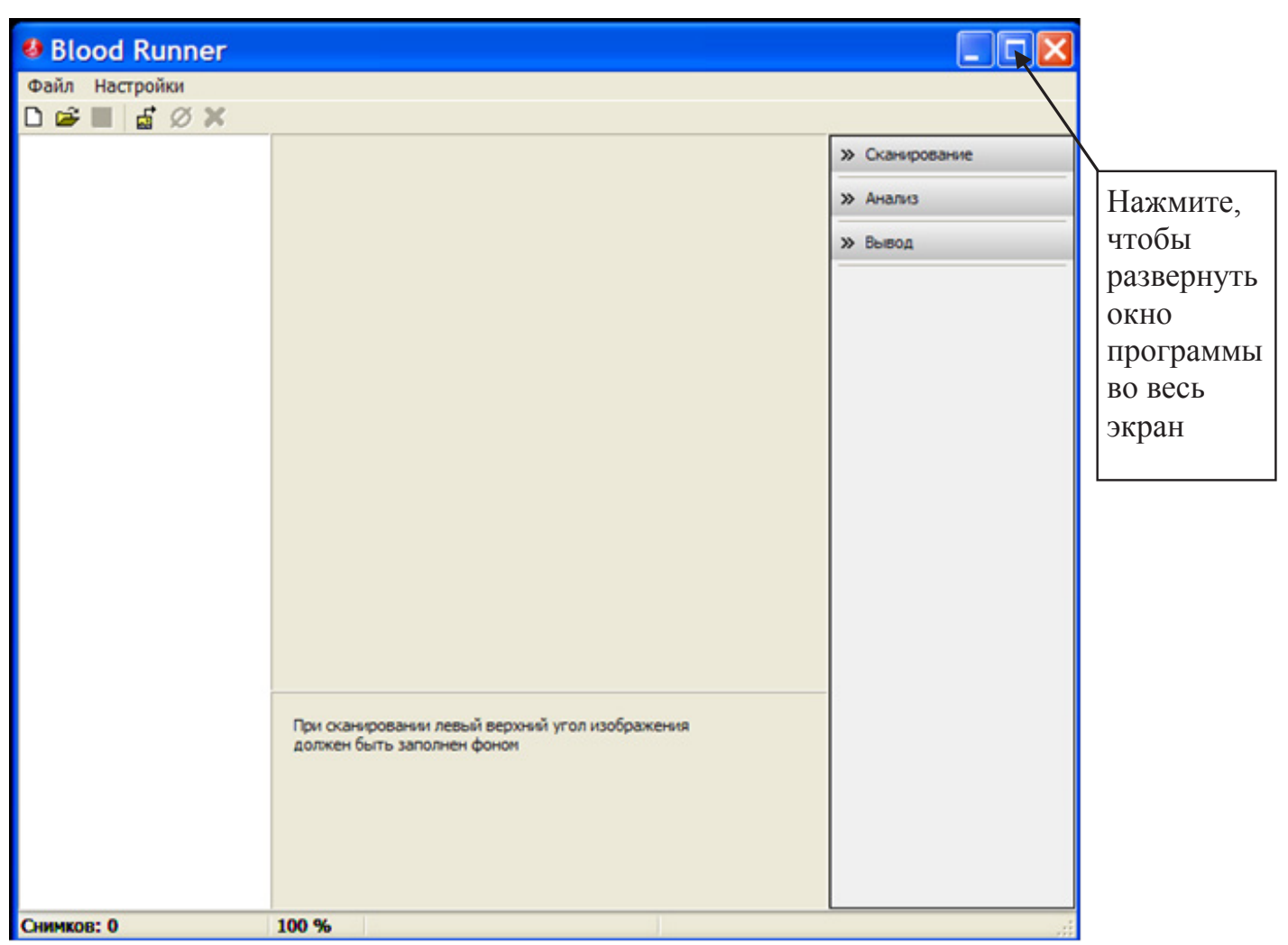

Puс. 1. Окно программы Blood Runner 
3. Нажать вкладку «Сканирование». Выбрать в качестве источника изображений видеокамеру, подключенную к микроскопу, и нажать кнопку «Сканировать».

4. Поверх окна основного модуля откроется окно модуля захвата изображений, в центре окна должен быть виден фрагмент мазка, помещенного под микроскоп (рис. 2).

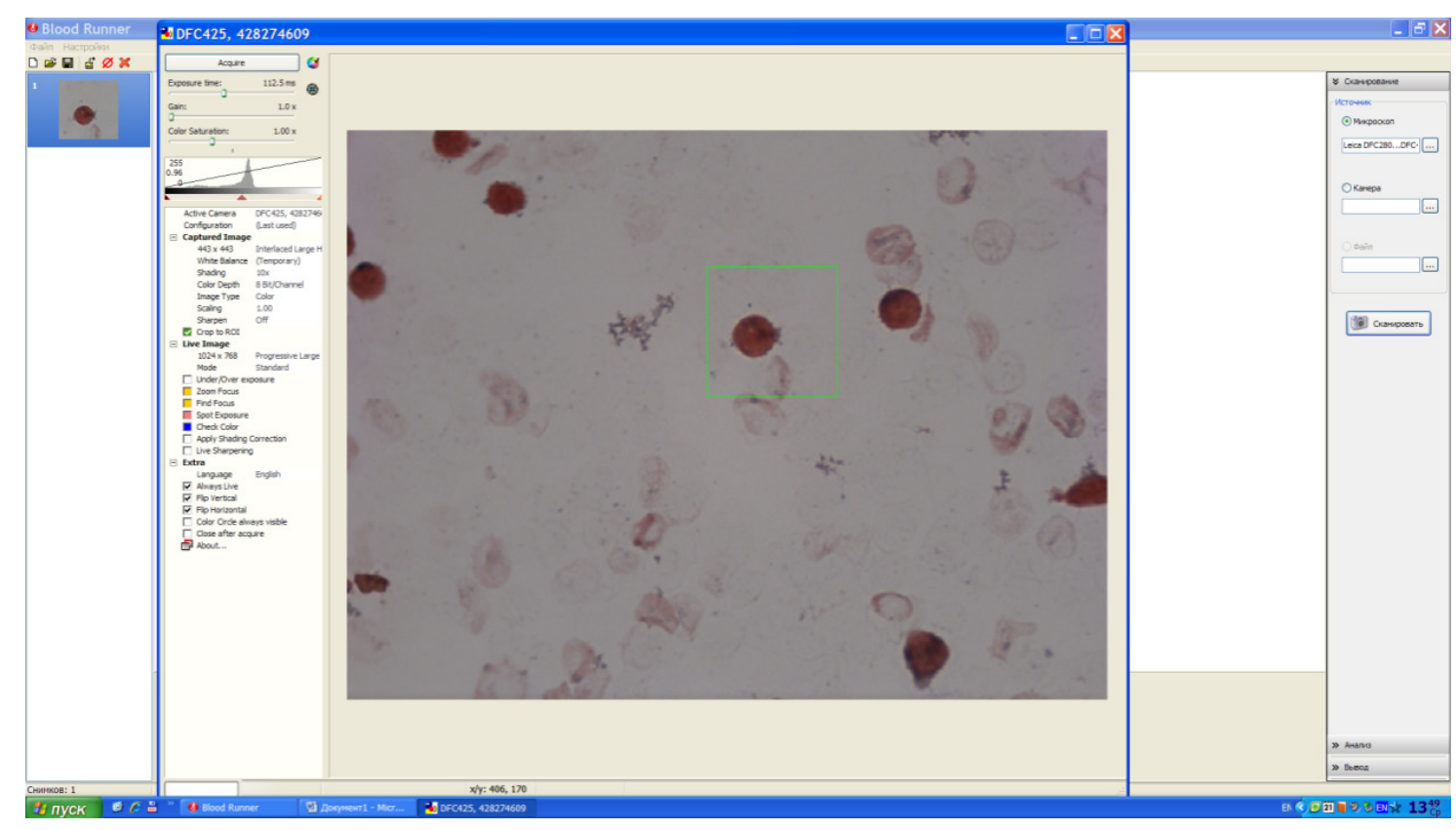

Рис. 2. Окно модуля захвата изображения

При первом использовании программы необходимо настроить несколько параметров, указанных в правом верхнем углу (рис. 3).

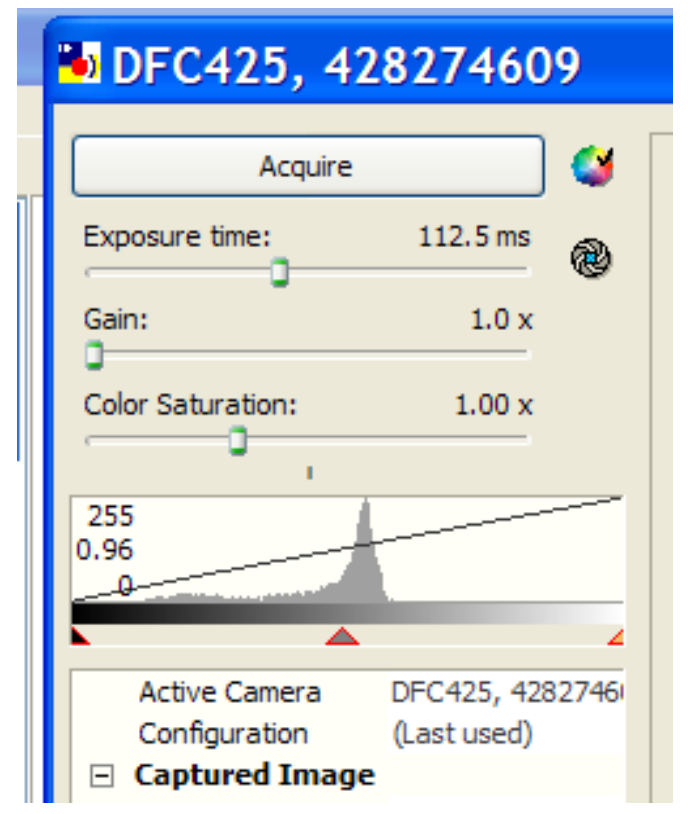

Рис. 3. Настройка основных параметров съемки 
Экспозиция (Exposure time). Этот параметр зависит от интенсивности освещения в микроскопе; в наших условиях он равен 112,5 мс. Необходимо настроить микроскоп таким образом, чтобы освещение было мягкое, не резало глаза исследователя и фон у клеток был светло-серый. Следует избегать как слишком темных, так и слишком ярких изображений: засвеченные фотографии мало пригодны для обработки, темные - неэстетичны.

Gain и Color Saturation - всегда равны 1,00.

Бегунки на гистограмме - в положениях 0,96 и 255.

После всех настроек в центре модуля будет виден фрагмент мазка под микроскопом. Поле зрения видеокамеры более узкое, чем поле зрения в окуляры, поэтому на экране видна только часть (при правильной настройке камеры - центральная) зоны мазка, видимой в окуляры.

5. Далее необходимо внутри свободного пространства мазка, не занятого никакими клетками или другими объектами, без мусора, имеющего однородный серый цвет, нажать левую кнопку мыши и, держа ее нажатой, выделить небольшой прямоугольник (рис. 4). При отпускании кнопки мыши появится меню, необходимо выбрать первую строчку «White Balance». Это настройка баланса белого цвета, она автоматическая, больше ничего не требуется.

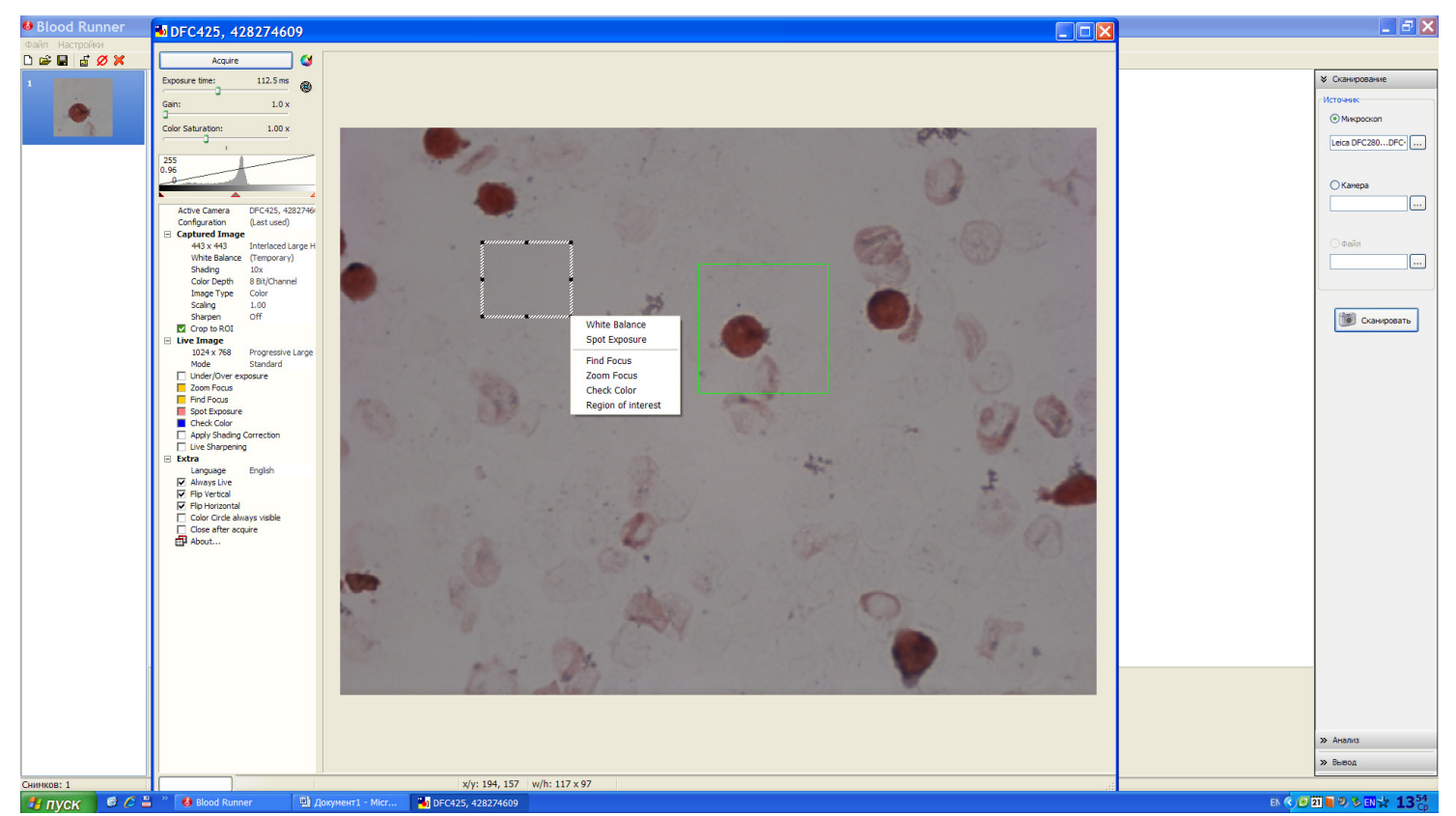

Рис. 4. Съемка клетки

В центре мазка на мониторе можно увидеть квадрат/прямоугольник зеленого цвета. Он показывает непосредственно ту область мазка, которая будет сфотографирована. Его размеры можно произвольно менять: если нажать точно на зеленую линию, прямоугольник станет белым с черными точками; нажимая мышью на эти точки и растягивая их в стороны, можно изменять размеры прямоугольника. При этом внизу экрана отображаются его 
размеры. Для фотографирования клеток с целью последующего их обсчета ЦБХ методом необходимо использовать один и тот же размер квадрата. Мы используем размер 175 х 175, так как туда помещаются даже самые большие клетки. Главное при этом, чтобы края клетки не касались краев квадрата.

6. Итак, поместив зеленый квадрат таким образом, чтобы интересующая нас клетка находилась посередине, необходимо окончательно навести на резкость и нажать кнопку «Асquire» в левом верхнем углу окна. Начнется процесс захвата изображения. Его время зависит от быстродействия компьютера и обычно не превышает 3-4 с. Во время захвата изображения важно не трогать микроскоп руками, чтобы не получить смазанное изображение. По окончании захвата изображения будет видно, как клетка помещается в хранилище клеток, слева от окна захвата изображения (рис. 5). Если рядом с клеткой есть какие-то объекты светлее ее по окраске (например, разрушенные эритроциты или мусор), то они не помешают последующему процессу обработки. Но вот другие окрашенные клетки сильно влияют на обработку, поэтому снимать две клетки в одном квадрате нельзя!

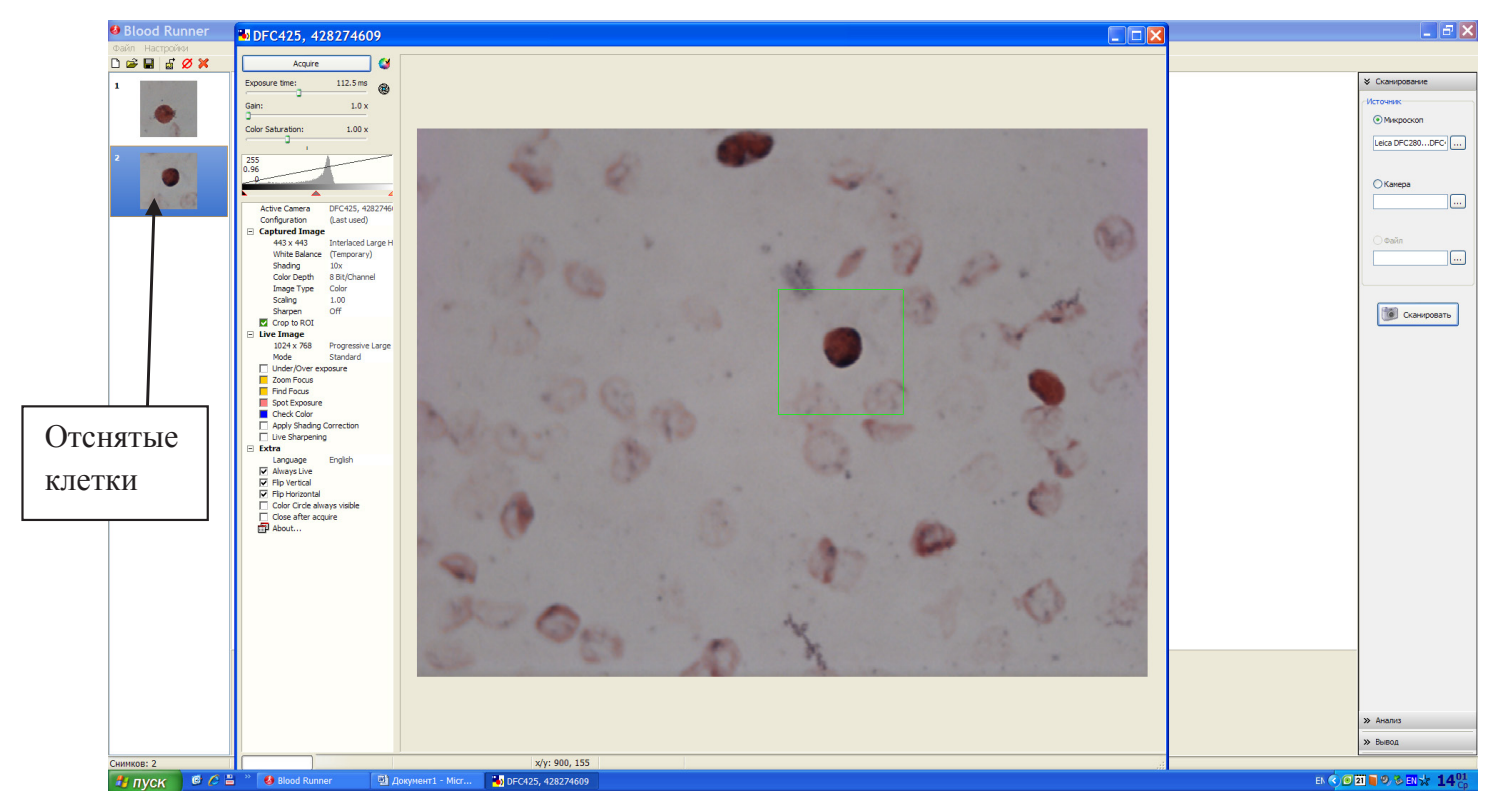

Рис. 5. Съемка клеток

7. Если в данном поле зрения есть еще объекты для съемки, нужно мышкой переместить квадрат (не изменяя его размеров!) в другую область и опять нажать «Acquire». Далее, глядя на экран монитора или в окуляры, перемещать мазок до обнаружения следующего объекта съемки. Действовать аналогичным образом, пока не наберется требуемое количество клеток.

8. Проводник, где выбираем папку для сохранения и вводим имя файла, нажимаем кнопку «Сохранить». 
9. Набрав нужное количество клеток с мазка, закрыть модуль захвата изображения (красный крестик в правом верхнем углу). Попадаем в предыдущее (основное) окно программы, справа в котором отображается вертикальный ряд всех отснятых клеток.

10. Теперь необходимо сохранить отснятую серию, для чего нажимаем кнопку «Сохранить серию» или в меню «Файл» выбираем «Сохранить серию», или просто сочетанием клавиш «Ctrl»+ «С» открывается стандартное окно. Серия клеток сохранена в формате brd.

11. Для съемки нового мазка необходимо начать новую серию, нажав кнопку «Начать новую серию измерений», далее кнопку «Сканирование» и т.д. с п. 1.7, так как все предыдущие настройки программы автоматически сохраняются. 


\section{ПРИЛОЖЕНИЕ № 7}

Инструкция по работе с программой захвата изображений Cell Composer

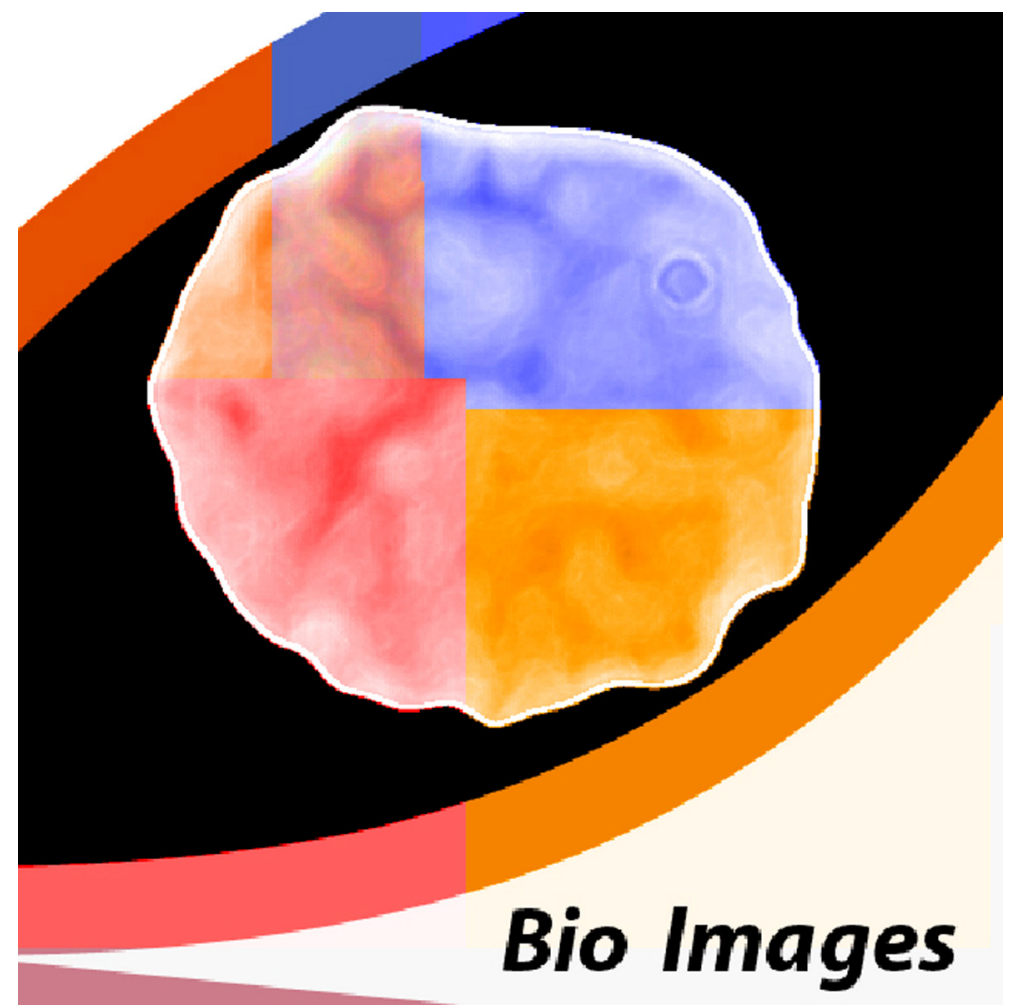

- важно
- обратите внимание
- совет
- полезная информаиия 


\section{1. Установка программы}

Установка программы не требуется. Необходимо скопировать на жесткий диск компьютера папку программы Cell Composer, двойным щелчком запустить файл «BioImages .exe». Появится окно программы. Программа готова к работе.

\section{2. Общая информация}

Программа позволяет обрабатывать изображения, полученные ЦБХ методом, и получать количественные и «площадные» характеристики следующих веществ: диформазан нитросинего тетразолия, моноформазан нитросинего тетразолия и нейтральный красный.

Работа программы основана на создании математической модели, отражающей связь спектров освещения источника, спектров поглощения веществ (диформазана, моноформазана и нейтрального красного), квантовой эффективности каналов камеры и оптической толщи вещества с цветом соответствующего пикселя, полученного RBG-камерой. Модель учитывает нелинейность системы.

«Площадные» характеристики отражают площадь каждого из веществ по заданным уровням интенсивности (количество уровней задается пользователем), например для трех уровней вычисляется площадь слабо-, среднеи сильноокрашенных фрагментов изображения по каждому из трех веществ. Суммарная площадь всех уровней аналогична той площади окраски, которую мы считали перед разработкой этой программы. То есть именно по общей площади можно сравнивать результаты с предыдущими.

Количественные характеристики отражают общее количество вещества (в конечном итоге - в мкМ, пока в у.е.) в полученном изображении клетки на основании данных об оптических свойствах веществ и системы получения изображения (источник освещения, микроскоп, камера).

Программа использует автоматический алгоритм сегментации изображения применительно к разделению клетки и фона на микроскопических изображениях лимфоцитов. Алгоритм успешно обрабатывает подавляющее большинство (> 95 \%) различных изображений клеток: при разной экспозиции, освещённости и вне зависимости от состояния и окраски клетки (необходимо только, чтобы как минимум часть границы клетки была различима на фоне), в том числе с умеренно зашумлённым фоном при условии, что в кадре полностью находится только одна клетка. Результатом сегментации изображения является маска, определяющая форму лимфоцита и вычисленная на основе задания масштабного отрезка площадь видимого сечения клетки.

Программа имеет удобный и интуитивно понятный интерфейс, при наведении мыши на кнопки отражается подсказка.

Программа работает с изображениями в форматах jpg, возможно, и с другими форматами, но они не тестировались. 


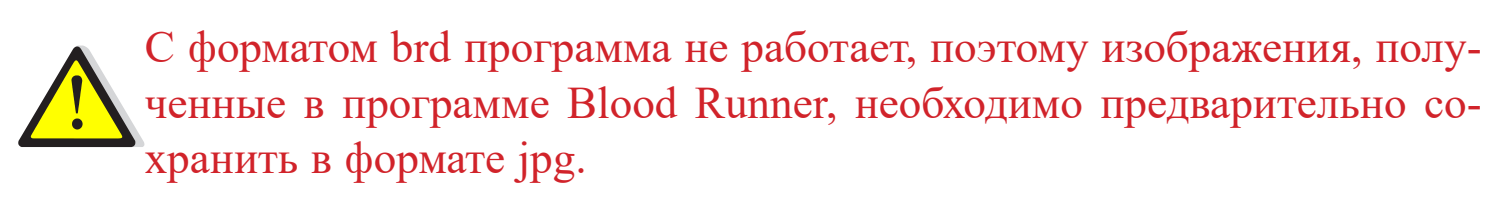

Программа выдает результаты трех видов:

1) Глобальный отчет - в виде текстового файла (.txt), который содержит следующую информацию по ВСЕМ обработанным изображениям, всегда имеет название «GLOBAL REPORT»:

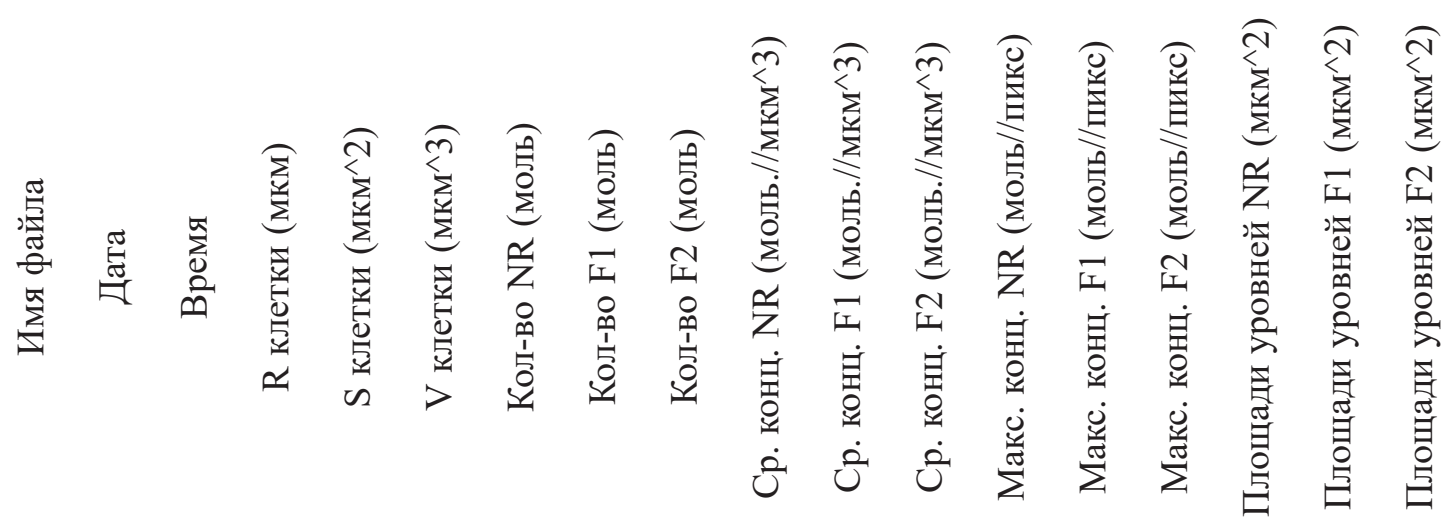

$\begin{array}{llllllllllllllllll}1 & 2 & 3 & 4 & 5 & 6 & 7 & 8 & 9 & 10 & 11 & 12 & 13 & 14 & 15 & 16 & 17 & 18\end{array}$

1. Имя обработанного файла.

2. Дата обработки.

3. Время обработки.

4. Радиус клетки (мкм).

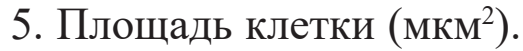

6. Объем клетки $\left(\right.$ мкм $\left.^{3}\right)$ - вычисляется эмпирически, исходя из того, что клетка имеет форму шара.

7. Вычисленное количество вещества «Нейтральный Красный (NR)», моль.

8. Вычисленное количество вещества «Диформазан (F1)», моль.

9. Вычисленное количество вещества «Полуформазан (F2)», моль.

10. Средняя концентрация вещества «Нейтральный Красный (NR)»на объем, моль/мкм³.

11. Средняя концентрация вещества «Диформазан (F1)» на объем, моль $/$ мкм $^{3}$.

12. Средняя концентрация вещества «Полуформазан (F2)» на объем, моль/мкм ${ }^{3}$.

13. Максимальная концентрация вещества «Нейтральный Красный (NR)» в одном пикселе, моль/пикс. 
14. Максимальная концентрация вещества «Диформазан (F1)» в одном пикселе, моль/пикс.

15. Максимальная концентрация вещества «Полуформазан (F2)» в одном пикселе, моль/пикс.

16.-18. Площадь окраски соответствующего вещества (NR, F1, F2) в каждом выбранном уровне (количество уровней и максимальное значение задается пользователем, см. п. 4.4.1 и 4.4.4).

Например, если выбрано 3 уровня и максимальное значение концентраиии соответствующего вещества, равное 1 моль, то будет получено три значения (в глобальном отчете они разделены точкой с запятой):

а. Площадь окраски, в которой концентрация в каждом пикселе изображения равна от 0 до 0,33 моль/пикс;

b. Площадь окраски, в которой концентрация в каждом пикселе изображения равна от 0,33 до 0,66 моль/пикс;

с. Площадь окраски, в которой концентрация в каждом пикселе изображения равна от 0,66 до 1 моль/пикс.

Важно понимать, что при каждом запуске программы и обработке клеток, даже уже обработанных ранее, результаты обработки ДОПИСЫВАЮТСЯ в конец глобального отчета, а записи, полученные ранее, не удаляются, а сохраняются в верхних строчках глобального отчета.

\section{2) Локальный отчет}

Локальный отчет подобен глобальному отчету, но представляет собой информацию по КАЖДОМУ обработанному изображению в виде отдельного текстового файла. Файл локального отчета именуется по имени обработанного изображения с добавлением в конце слова «report».

Пример: при обработке изображения 1-30006.jpg будет создан файл локального отчета с именем «1-30006.jpg_report».

В отличие от глобального отчета, при новом обсчете тех же клеток
файл локального отчета заменяется на новый.

\section{3) Изображения}

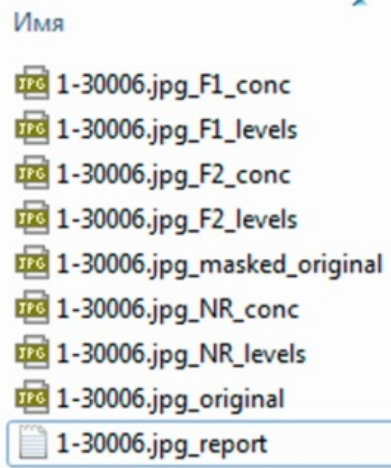

Для каждого обработанного файла генерируется восемь изображений в формате jpg. Каждый файл изображения имеет название, соответствующее названию обработанного файла и через нижнее тире - тип файла: «*_ тип файла»:

*_original - оригинал изображения обрабатываемой клетки;

*_masked_original - оригинал изображения с выделенной (маскированной) клеткой (необходим для контроля правильности маскирования клетки); 
*_F1_conc - показывает выделение по F1, непрерывное, интенсивность цвета зависит от количества вещества в каждом пикселе, рядом отображается диаграмма шкалы концентраций;

*_F1_levels - выделение по F1 дискретное, в соответствии с заданным количеством уровней, рядом отображается диаграмма шкалы концентраций для каждого уровня;

*_F2_conc и *_NR_conc - аналогично для F2 и NR;

*_F2_levels и *_NR_levels - аналогично для F2 и NR.

П При новом обсчете тех же клеток файлы также заменяются на новые.

\section{3. Алгоритм работы в программе}

Обработка полученных изображений клеток осуществляется по следующему алгоритму:

0. Установка и сохранение настроек программы (выполняется один раз при первом сеансе работы).

1. Загрузка сохраненных настроек.

2. Загрузка изображений для обработки.

3. Обработка изображения:

a. Маскирование клетки;

b. Вычисление концентраций веществ;

с. Обработка результатов и формирование файлов отчета;

4. Проверка корректности маскирования изображений и изменение настроек для исправления ошибок маскирования (см. п. 4.2), выполнение пункта 3 на новых настройках.

5. Перевод файлов отчетов в Excel, построение диаграмм и анализ результатов.

Пункты 0, 1, 2 и 4 выполняются пользователем, п. 3 - выполняется программой в автоматическом либо в ручном режимах.

1. Загрузка сохраненных настроек. Выбираются из выпадающего меню в поле списка настроек.

2. Загрузка изображений для обработки осуществляется нажатием кнопки «Добавить файлы в лист»

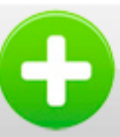

При этом открывается окно проводника, необходимо выделить файлы, предназначенные для обработки, и нажать кнопку «Открыть».

Выбранные файлы появятся в окне «Имя файла/состояние»; рядом с каждым файлом отражается процесс обработки («Ждет обработки/ обрабатывается/готов»). 
Динамику процесса обработки каждого изображения можно также наблюдать на цветных полосах под кнопками ручной обработки «Маскирование», «Вычисление концентраций», «Обработка результатов», «Сохранить» на нижней панели инструментов». Оранжевый цвет означает, что процесс еще не начат, желтый - процесс идет, зеленый - процесс завершен.
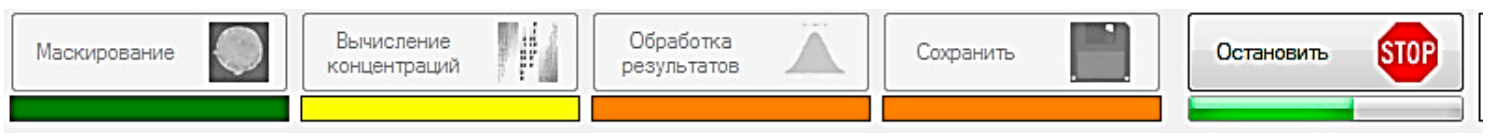

Процесс обработки всегда можно остановить кнопкой «Стоп». После этого можно добавлять/удалять файльь в/из поля списков файлов, менять настройки. При этом все локальные записи по клетке (изображения и локальный отчёт) будут перезаписываться, а общий (глобальный) отчет будет дополняться.

3. Обработка изображений. Если все необходимые настройки уже сделаны, для автоматического запуска процесса обработки необходимо нажать кнопку «Начать автоматическую обработку изображений»

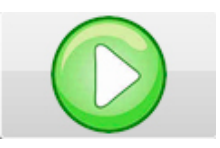

Программа начнет автоматическое выполнение п. 3 для всех загруженных файлов изображений.

Возможно обрабатывать изображения отдельно по п. 3a-3c - это так называемый «руиной режим», для этого необходимо последовательно нажимать кнопки «Маскирование», «Вычисление концентраций», «Обработка результатов», «Сохранить» на нижней панели инструментов для каждого загруженного изображения.

4. Проверка корректности маскирования. После получения результатов необходимо просмотреть все файлы *_masked_original для обработанных изображений и убедиться в корректности маскирования всех обрабатываемых клеток. При необходимости внести изменения в настройки маскирования (см. п. 4.2).

\section{5. Перевод файлов отчетов в Excel}

Для этого необходимо открыть MS Excel, а в нем - нужный файл GLOBAL_REPORT.txt. Чтобы программа увидела текстовый файл, нужно выбрать «Показать все файлы». В открывшемся окне щелкаем «Далее»; ставим галочку напротив «точка с запятой»; щелкаем кнопку «Готово»- все данные готовы для анализа.

\section{4. Установка настроек}

Работа с программой начинается с установки настроек, которые могут и должны быть сохранены (под определенным именем) и в начале следующего сеанса работы загружены. 
Для перехода в меню настроек необходимо нажать в правом нижнем ряду кнопку «Показать/скрыть настройки»:

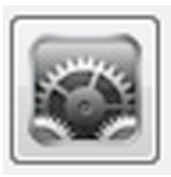

Появятся шесть вкладок:

1. Расположение файлов.

2. Маскирование.

3. Вычисление концентраций.

4. Обработка результатов.

5. Параметры отображения.

6. Настройка изображений.

\section{1. Расположение файлов}

В этой вкладке задается местоположение результатов обработки, т.е. глобального и локальных отчетов.

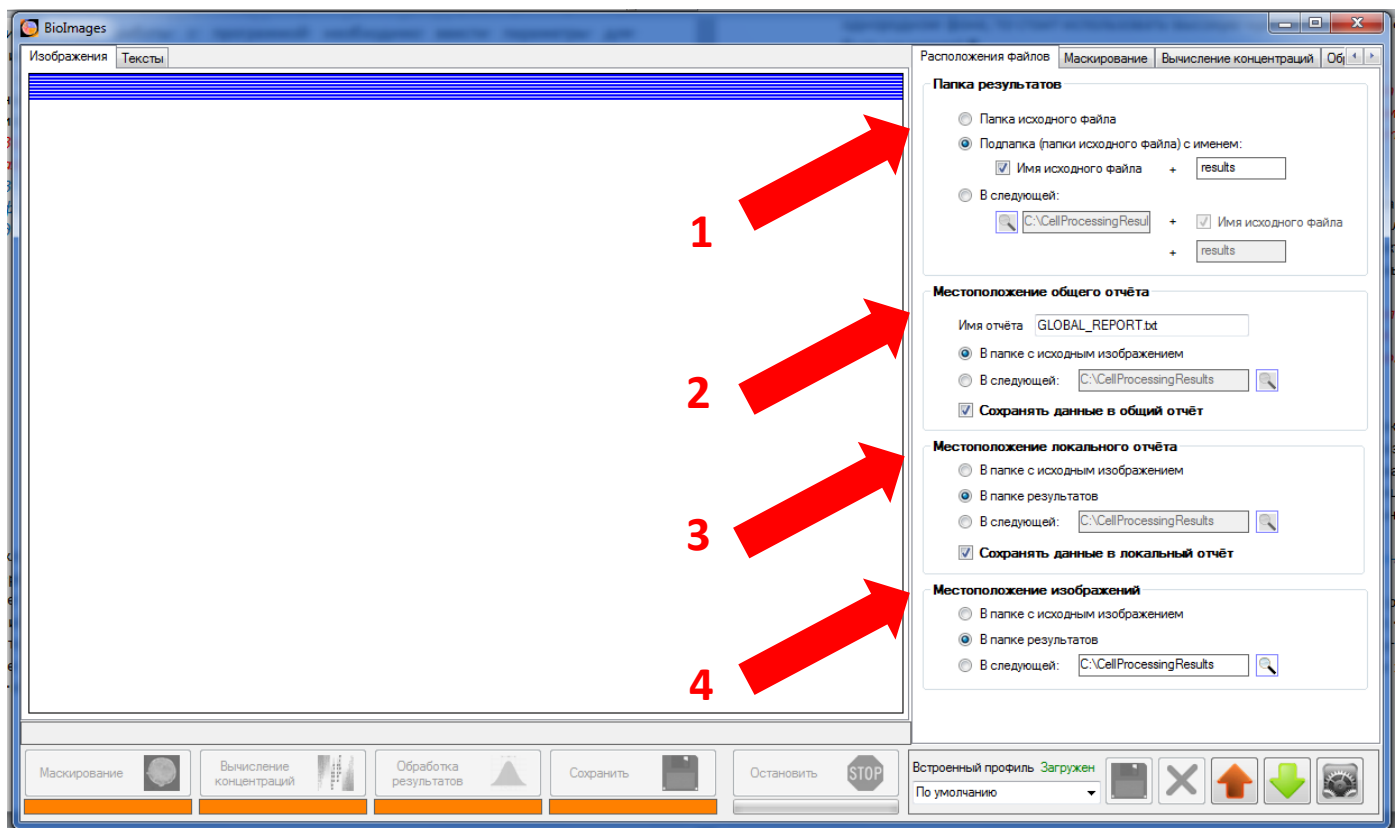

1. В поле «Папка результатов» определяется, где будут храниться все результаты вычислений по клетке (объекта), кроме глобального отчета. Для каждой клетки папка может быть своя, а может быть общая.

2. В поле «Местоположение общего отчета» можно настроить местоположение и название итогового отчета обработки.

Данные в глобальный отчет по группе объектов добавляются. Если группа клеток была обработана сначала с одними настройками, потом с другими, то предыдущие результаты не стираются из глобального отчета. 
3. В поле «Местоположение локального отчета» можно настроить местоположение отчета по каждой клетке.

4. В поле «Местоположение изображений» можно настроить местоположение, где будут находиться результирующие изображения клеток (исходное изображение, концентрации и площади веществ по слоям).

Рекомендуются следуюшие настройки:

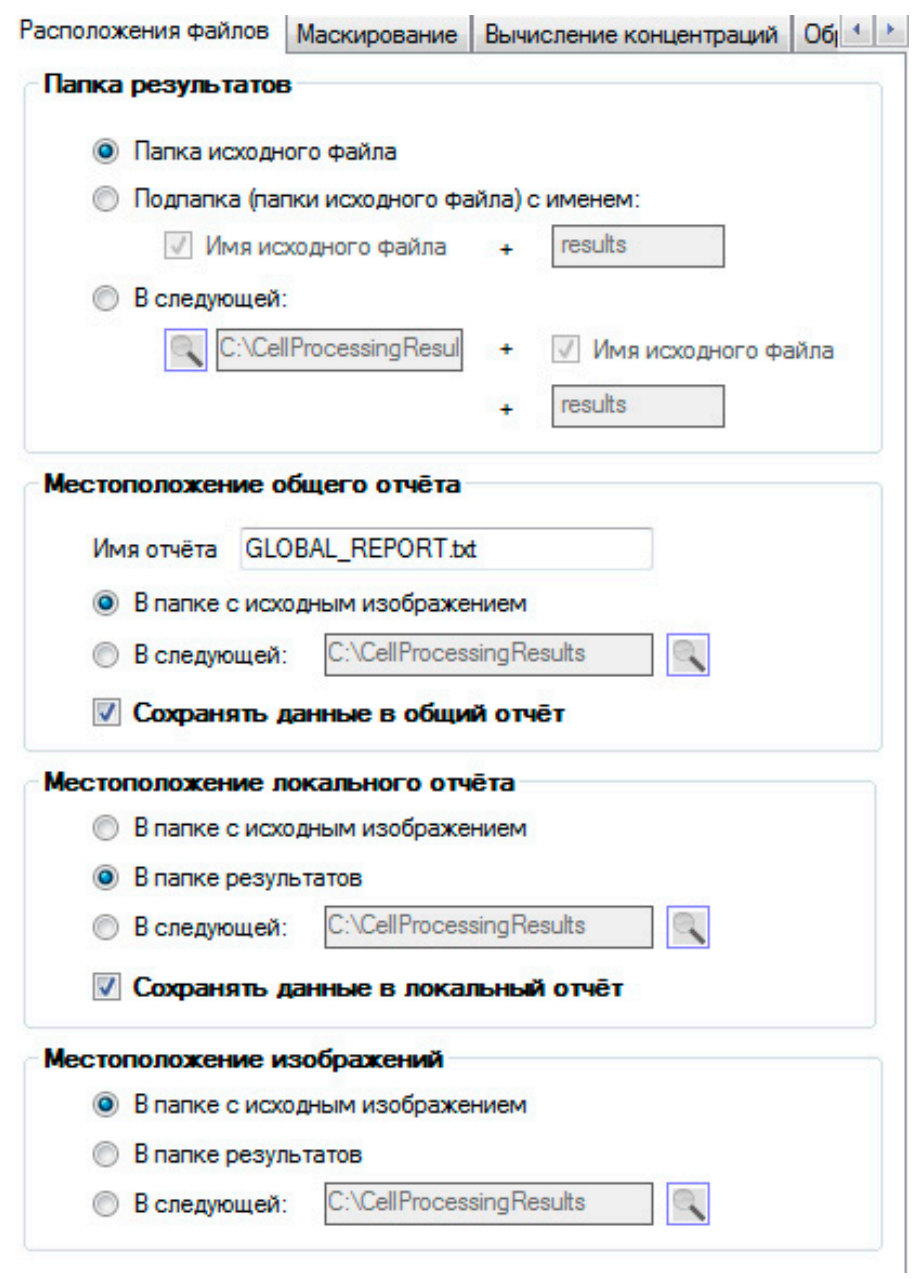

\section{2. Маскирование}

Маскирование - выделение области клетки, где будет происходить поиск нужных веществ на изображении. Правильное маскирование является залогом успешной обработки изображения.

В этой вкладке происходит выбор чувствительности маскирования. Чем выше чувствительность, тем сильнее одни и те же градиенты яркости изображения будут влиять на стягивание жгута.

Жгут - линия, которая во время обработки изображения постепен-

4 но сужается (стягивается) в размере, тем самым отсекает фон от самой клетки. 


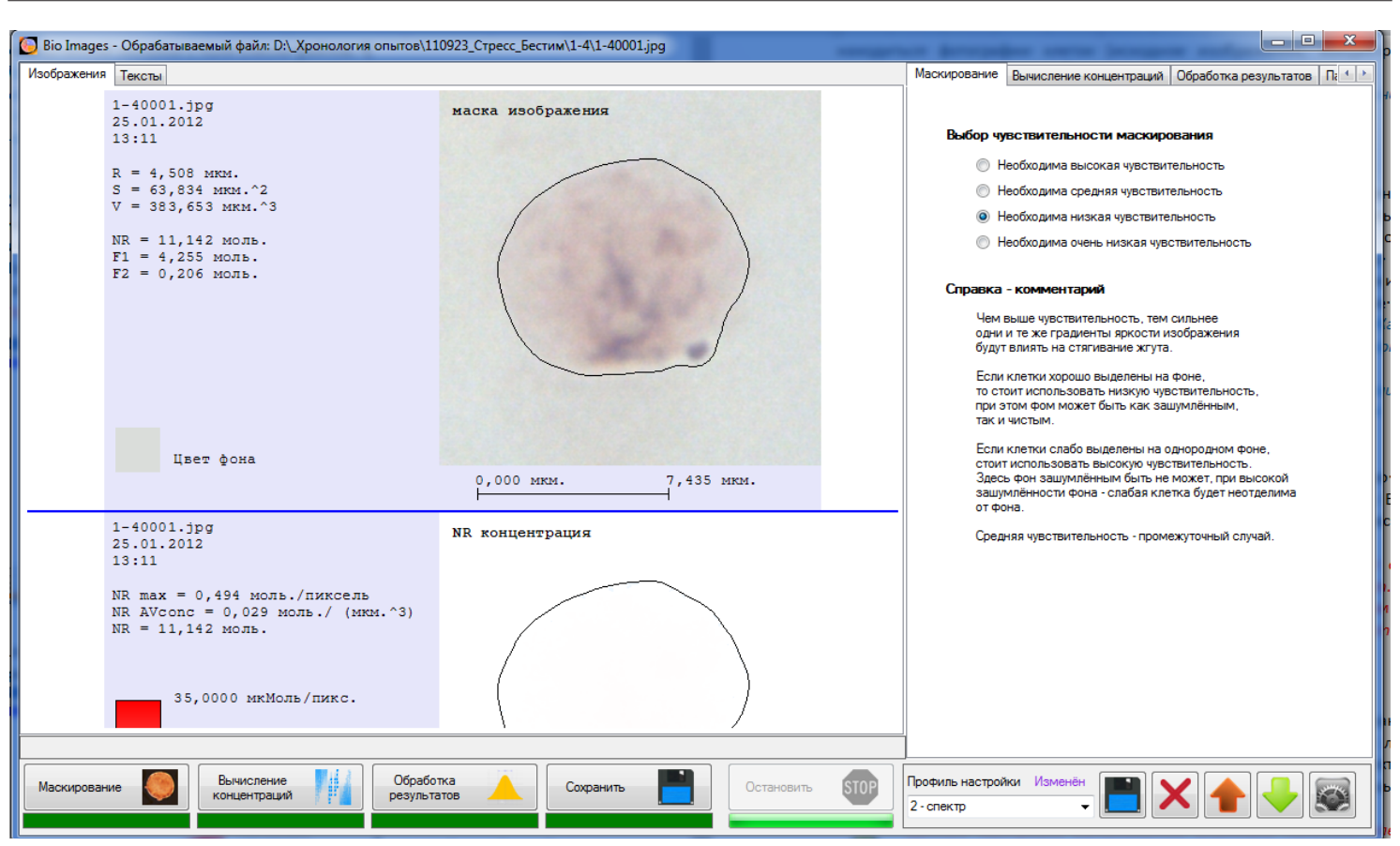

Если клетки хорошо выделены на фоне, то стоит использовать низкую или очень низкую чувствительность.

Пример. Правильная съемка и, соответственно, маскирование:
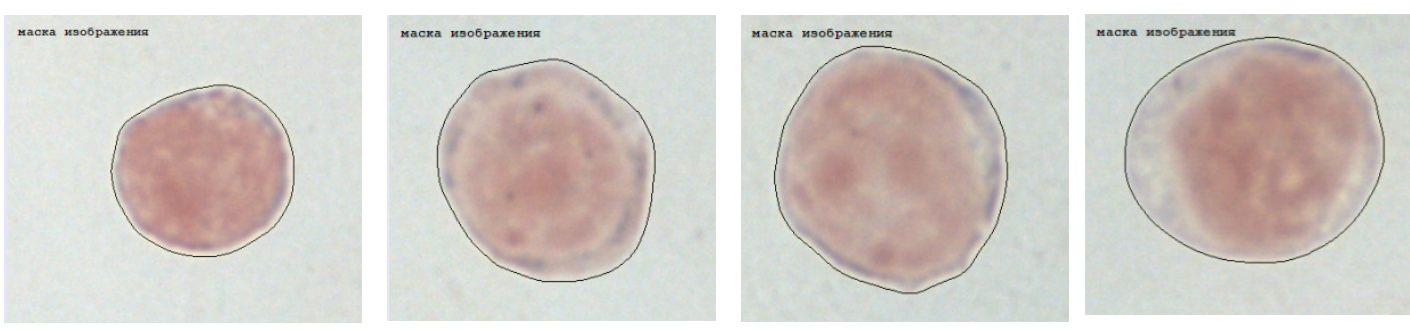

Если клетки слабо выделены на однородном фоне, то стоит использовать высокую чувствительность (но при этом фон зашумленным быть не должен!).

Например, такая ситуация часто бывает у проб с МАЛ или на ЭС. Эти пробы, вероятно, придется обсчитывать в режиме «высокой чувствительности».
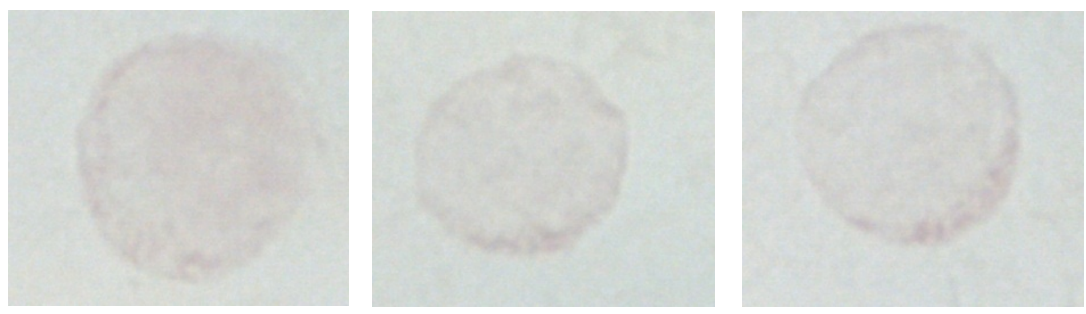

Также будет затруднено правильное маскирование клеток со следующими дефектами: 
1) грязь на мазке рядом с клеткой: в поле съемки не должны попадать никакие посторонние включения, кроме самой клетки
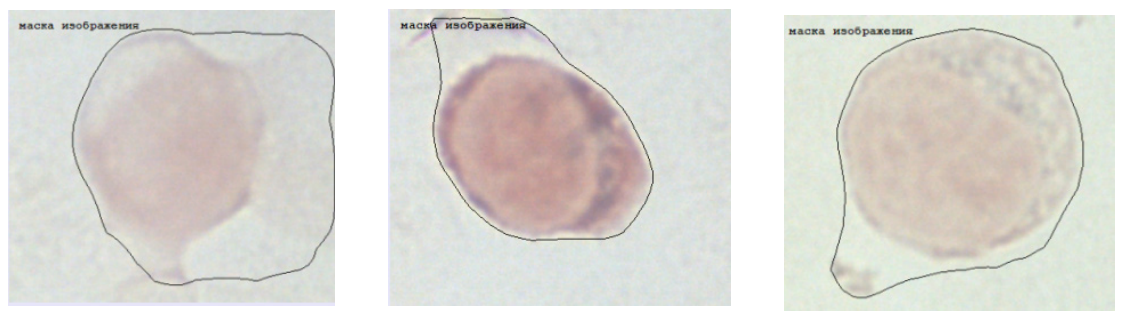

2) других клеток в поле съемки тоже не должно быть:
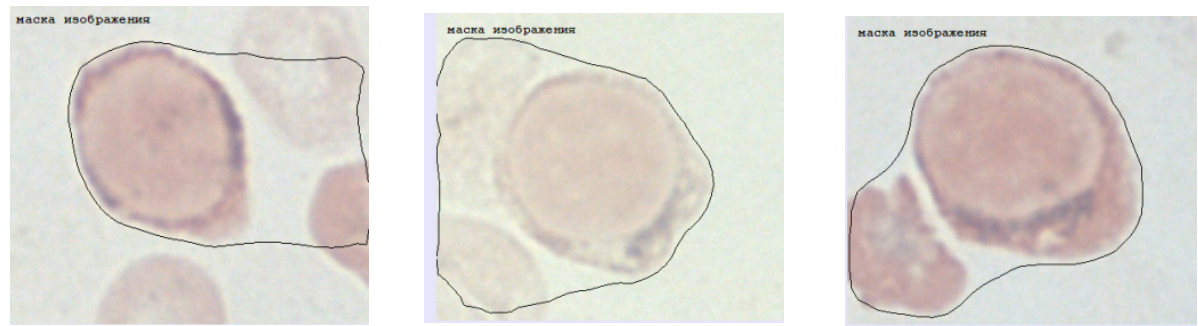

3) сами клетки не должны быть деформированы:
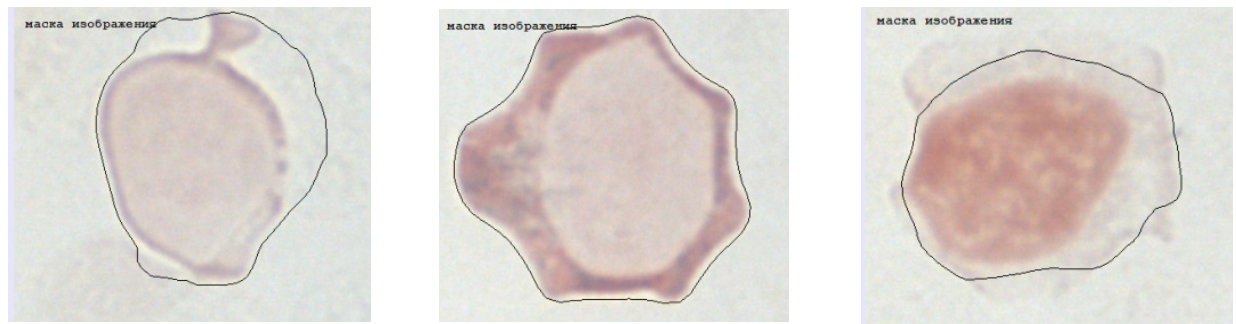

Если на мазке очень много деформированных клеток и мусора и трудно найти «идеальные» клетки, это в первую очередь означает, что мазок был сделан неправильно и большинство клеток на мазке попросту раздавлены. И уже во вторую очередь - что крыса тяжело больна и у нее все клетки «атипичные».

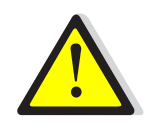

Программа позволяет «вытянуть» результаты с очень плохого по качеству фото клеток в режиме «высокой чувствительности», и теоретически она может обработать любой снимок. Однако это сильно замедляет работу программы и не стоит этим злоупотреблять.

\section{3. Вычисление концентраций}

В этой вкладке настраивается квантовая эффективность канала (технические параметры видеокамеры), спектр освещения (связан с лампой подсветки микроскопа) и спектр поглощения веществ (связан со спектром погло- 
щения исследуемых веществ, т.е. в нашем случае - нейтральный красный, формазан восстановленный (F1) и полуформазан (F2).

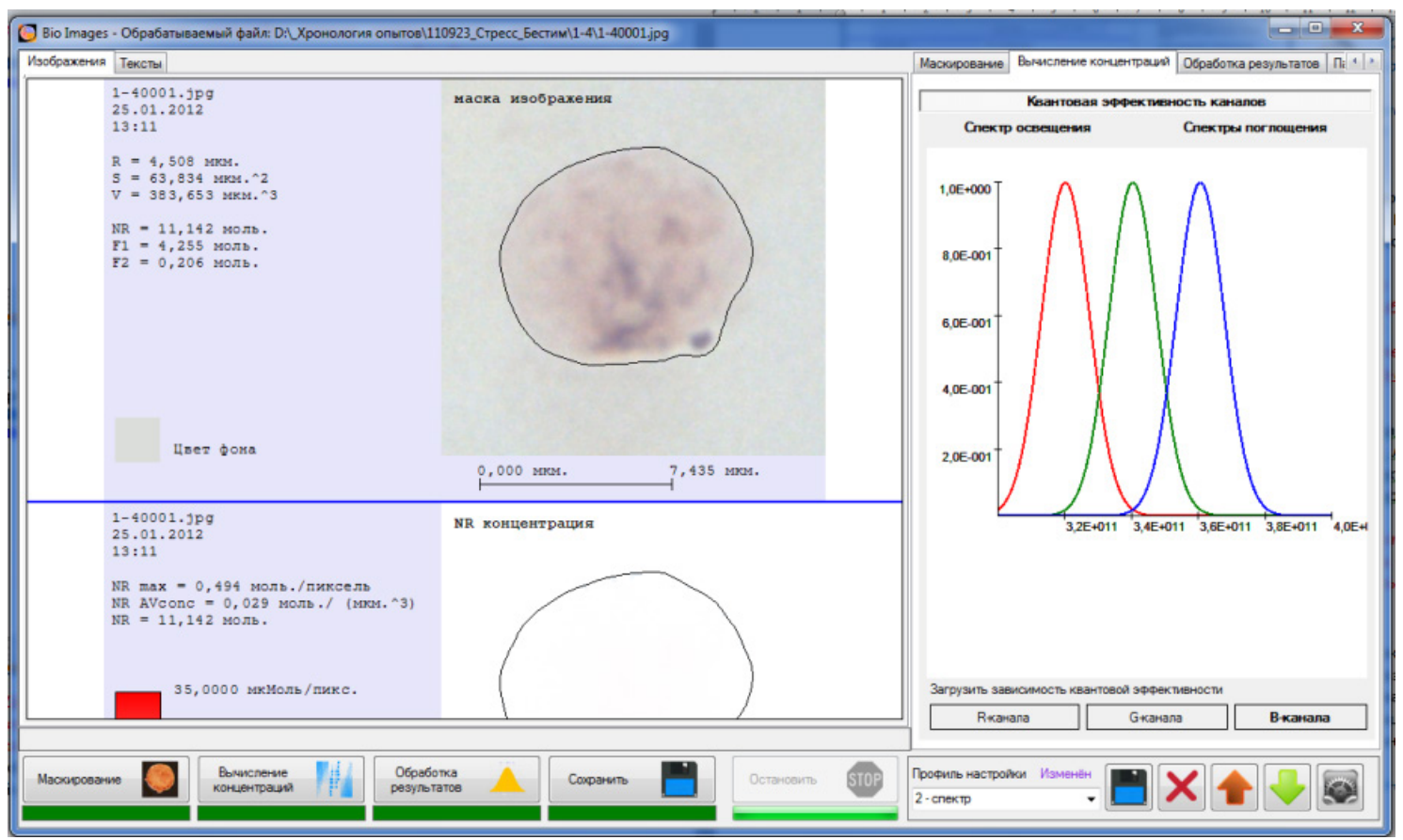

Данные настройки выполняются разработчиком и должны иметь ! для наших условий одни и те же значения. Их необходимо знать всем исследователям, однако изменение их в программе без дополнительных согласований недопустимо!

\section{4. Обработка результатов}

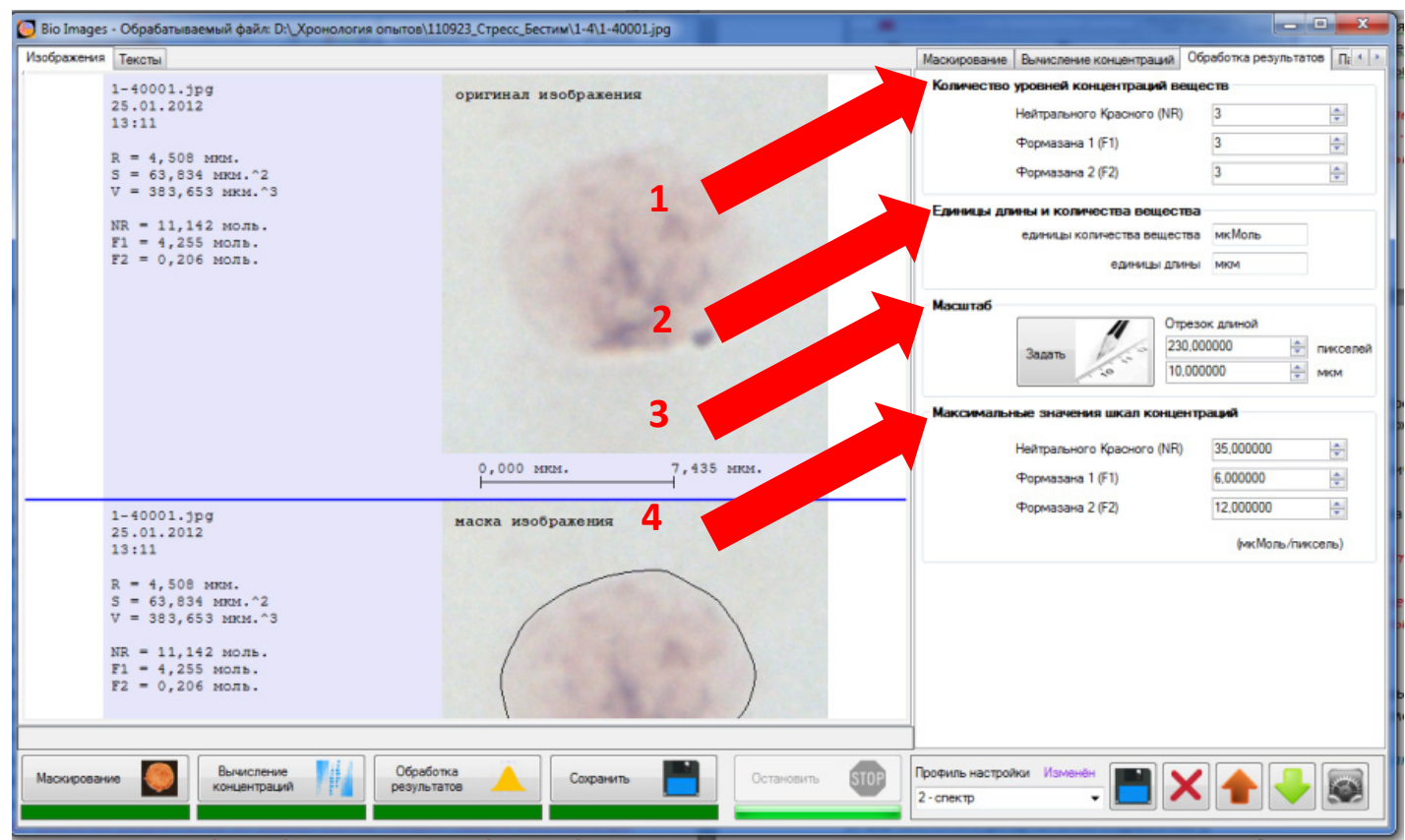


4.4.1. Настройка в поле «Количество уровней конц̧ентраций вещзеств» показывает, на сколько уровней (количество дискретных интервалов) разбивается диапазон концентрации веществ при вычислении площадей окраски различной интенсивности. Величина диапазона варьирует от нуля до максимального значения концентрации веществ в каждой клетке. Максимальные значения концентрации веществ в каждой клетке можно зафиксировать в поле «Максимальные значения шкал концентраций».

Наиболее вероятно, что будет принято общее для всех разделение на три уровня: «слабая», «средняя» и «сильная» интенсивность окраски.

4.4.2. В поле «Единищы длины и количества вещуества» можно ввести реальные единицы измерения вещества и длины (моль и мкм). На итоговые результаты это не влияет, а влияет только на отображение этих единиц в отчетных изображениях (в подписях фотографий).

\subsection{3. Определение масштаба}

Масштаб задается для того, чтобы задать соответствие между размерами изображения и реальными размерами объекта. Он влияет на численные результаты концентраций, площадей, объемов клеток. Если в процессе обработки изменить масштаб, то реальные размеры одного и того же объекта будут другие.

Для определения масштаба необходимо загрузить фото масштабной линейки, полученное на том микроскопе, где происходила съемка.

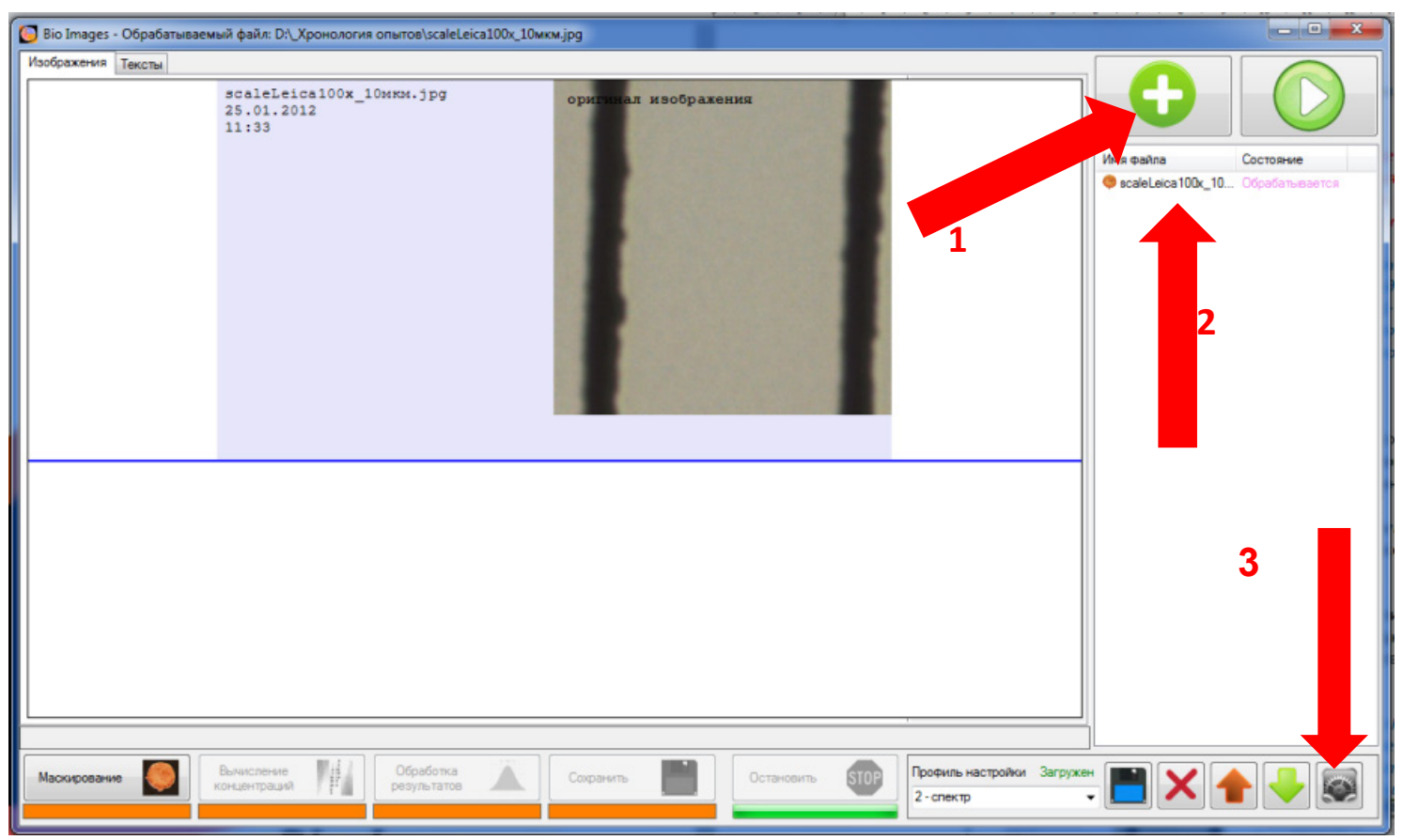


1. Щелкаем левой клавишей мыши на иконке «Добавить файлы в лист» и загружаем фото масштабной линейки. Фото загрузится и появится в поле списка файлов.

2. Дважды щелкаем в поле на название файла. Во вкладке «Изображения〉 появится фото масштабной линейки.

3. Щелкаем левой клавишей мыши на кнопку «Показать/скрыть настройки» и переходим на вкладку «Обработка результатов».

4. Щелкаем в поле «Масштаб» на кнопку «Задать».

5. Нажав и удерживая левую клавишу мыши, проводим красную линию от середины левой риски фото масштабной линейки до середины правой риски. Одновременно с этим в поле «Отрезок длиной» справа будет показано количество пикселей этого отрезка (красная линия пропадет).

6. Нажимаем кнопку «Готово».

7. Далее в поле «Масштаб» появляется возможность вручную ввести реальную величину отрезка (например, 10 мкм).

8. Щелкаем левой клавишей мыши на кнопку «Показать/скрыть настройки» и удаляем файл фото масштабной линейки с поля списка файлов.

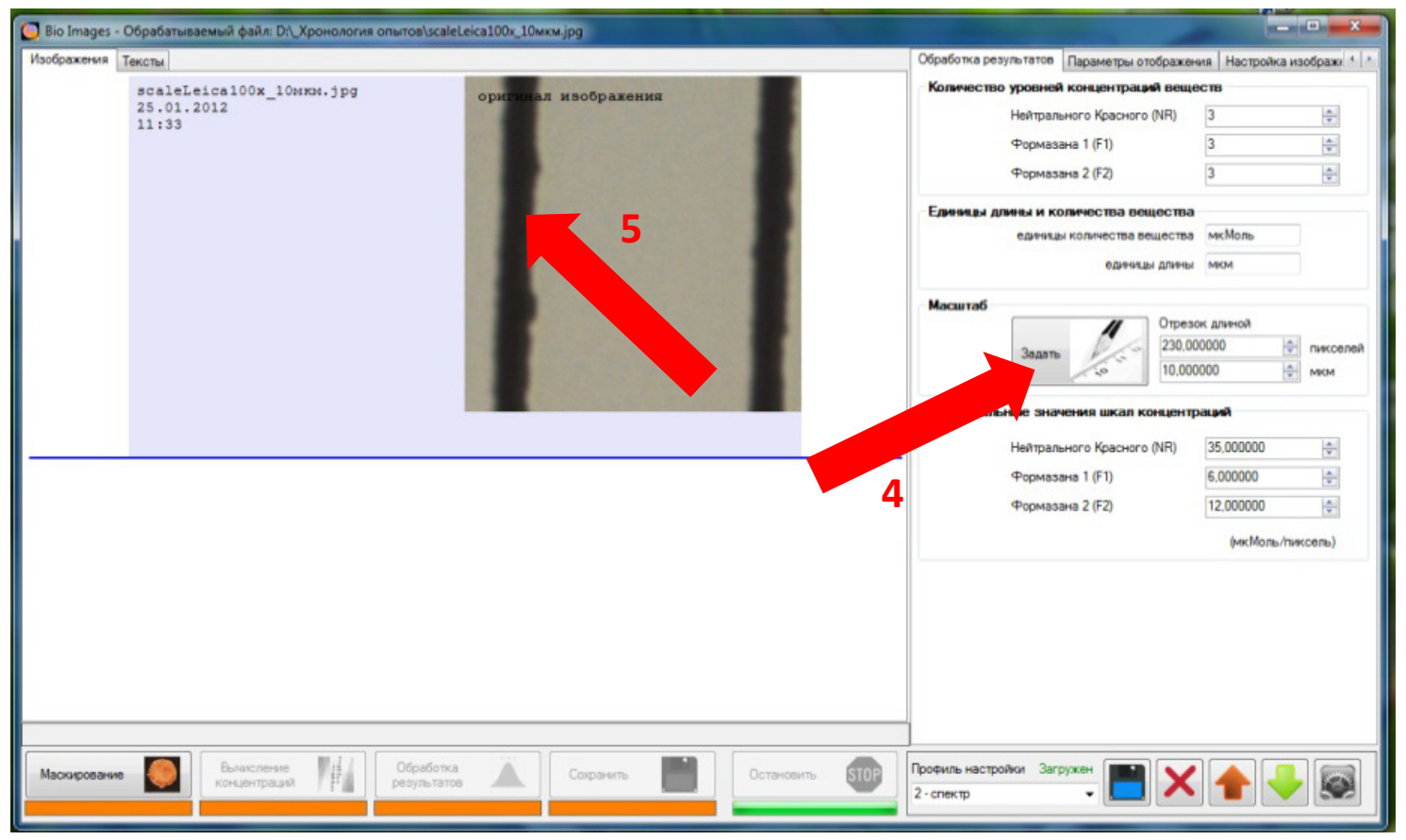

При работе на одном и том же оборудовании в поле «Масштаб» можно задать вручную уже известную величину отрезка (например, 230,00 пикселей) и соответствуюшую ей величину реального размера (например, 10 мкм). В этом случае загружать и обрабатьввать фото масштабной линейки не надо. 
4.4.4. В поле «Максимальные значения шкал концентращий» можно ввести максимальные значения шкалы концентраций по каждому веществу.

Программа построена таким образом, что если максимум будет ра-
вен нулю, то у каждой клетки при обработке будет свой максимум
(«автомасштабирование»)!

Если ввести значение, то максимум будет задан, и автомасштабирование для изображения концентраций применяться не будет.

Поэтому для сравнения результатов от разных клеток следует задать максимальную величину концентрации для каждого вещзества. Ее следует определить опьтным путем (т.е. предварительно обработав несколько разных объектов и найдя наибольшую величину максимальной концентрации). Если в данном пикселе изображения вычисленная концентрация превышает заданную максимальную, этот пиксель окрашивается программой в зеленый цвет. То есть если после обработки изображений программой на изображении много зеленого ивета, то необходимо поставить большее значение в поле «максимальные значения шкал концентраций».
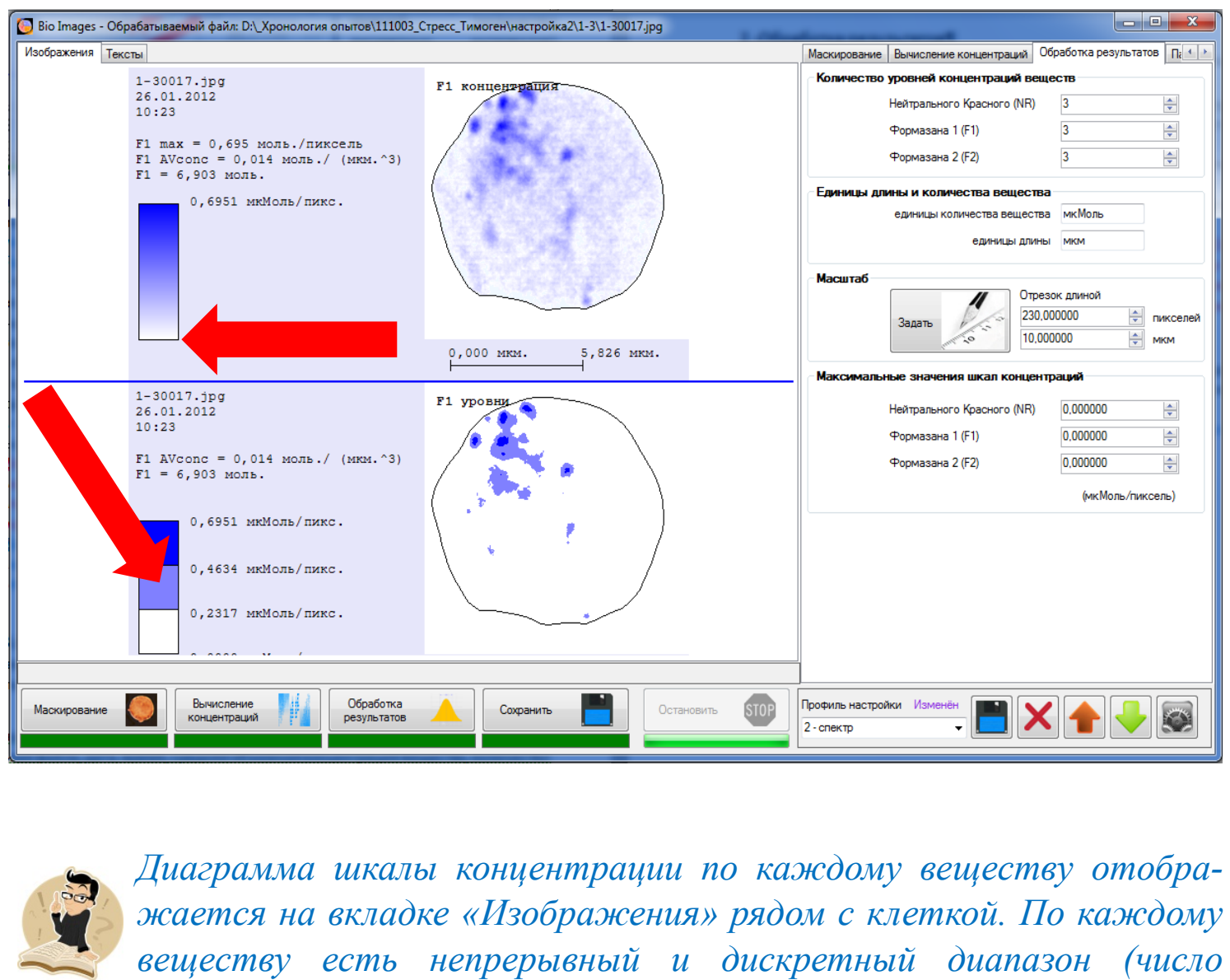

Диаграмма икаль конщентращии по каждому веществу отображается на вкладке "Изображения» рядом с клеткой. По каждому веществу есть непрерывный и дискретный диапазон (число уровней). 


\section{5. Параметры отображения}

Следующие две вкладки связаны с представлением итоговых изображений отчета. Настройка их не влияет на результат, а влияет только на вид фотографий, полученных в результате анализа.

1. «Ширина информационной полосы слева» определяет ширину поля, где появляются надписи (имя файла, дата, время, средняя объемная концентрация вещества, количество вещества, максимальная концентрация, легенда и т.д.).

2. «Ширина информационной полосы снизу» определяет ширину поля, где появляется масштабная линейка.

3. «Отступ текста от левого края рисунка» определяет центровку текста по горизонтали.

4. «Отступ текста от верхнего края рисунка» определяет центровку текста по вертикали.

Вв Ввод значения, можно наблюдать, как будет изменяться вид фотографий. Результатом этих настроек будут красивые фотографии, которые можно вставить в презентацию или публикацию.

\section{6. Настройка изображений}

В этой вкладке можно настроить отображение надписей в каждой из восьми фотографий клетки. В локальном отчете фотографии по каждой клетке будут иметь вид именно такой, каким мы настроим его в этой вкладке до запуска обработки результатов. Так же есть возможность убрать или показать надписи на фотографиях только с непрерывным или только с дискретным спектром.

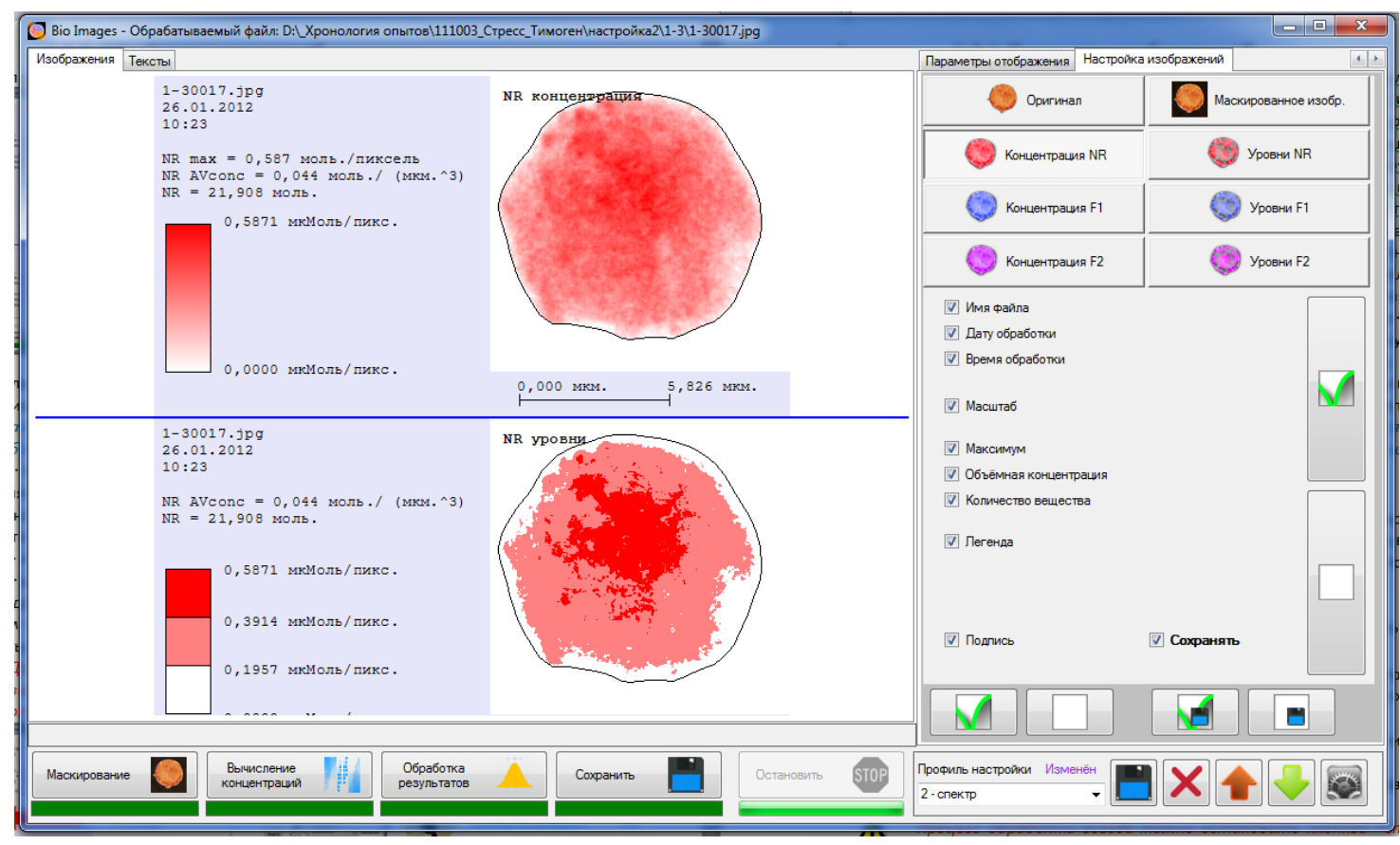




\section{7. Сохранение настроек}

Для сохранения сделанных настроек необходимо щелкнуть мышкой в поле с названиями настроек, появится подсказка «Имя текущего профиля. Для создания нового профиля введите имя нового профиля», нужно просто вписать новое название настроек нажать кнопку с изображением дискеты «сохранить текущие настройки», которая находится справа от этого поля.

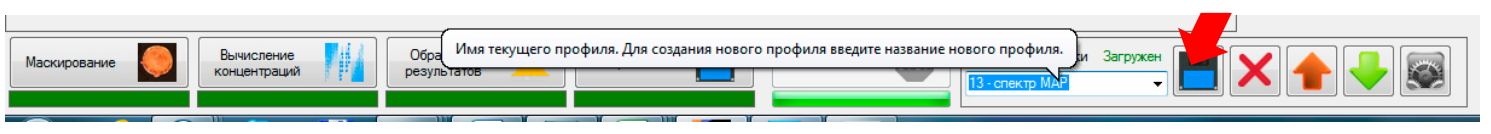

В поле «Профиль настройки» также находятся профили «по умолчанию», которые имеют фиксированные настройки. Их можно изменять в процессе работы, но сохранять нельзя (иконка дискеть погашена) и при закрытии програмлы изменения не сохраняются. 


\section{ПРИЛОЖЕНИЕ № 8}

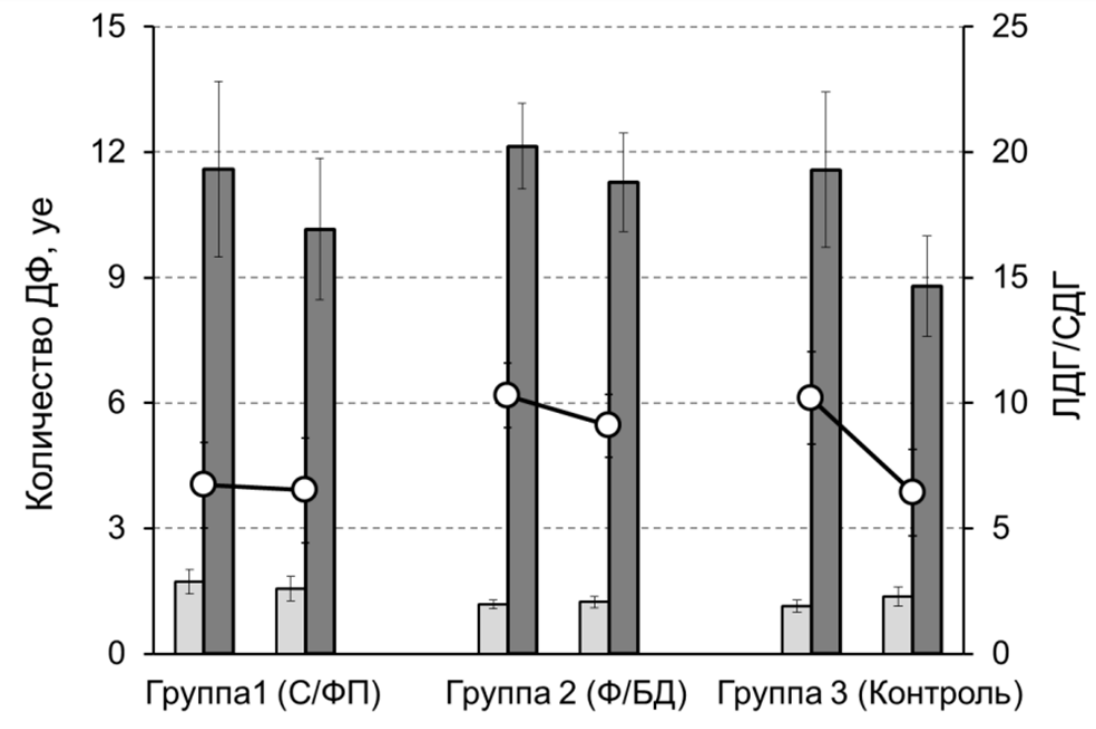

\section{口Сдг 口лдг олдг/Сдг}

Рис. 3. Изменения активности СДГ, ЛДГ, Эффект Варбурга (ЛДГ/СДГ) в лимфочитах крови двух групп пациентов с АБА и группе контроля при повторных измерениях (через 2 месяиа) 


\section{ПРИЛОЖЕНИЕ № 9}

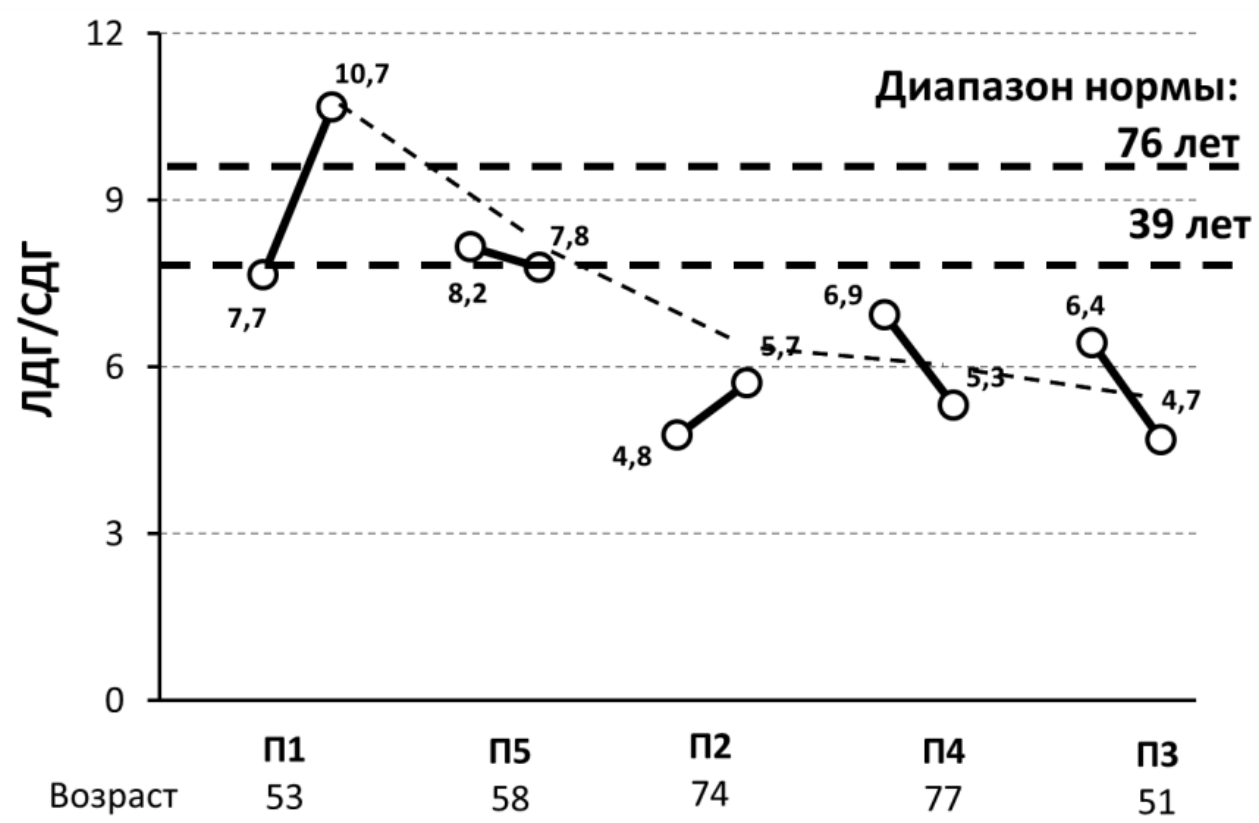

Рис. 4. Различия в показателе Эффекта Варбурга (ЛДГ/СГД) у пяти пациентов с АБА при повторных исследованиях по сравнению с показателями здоровых людей 


\section{ПРИЛОЖЕНИЕ № 10}

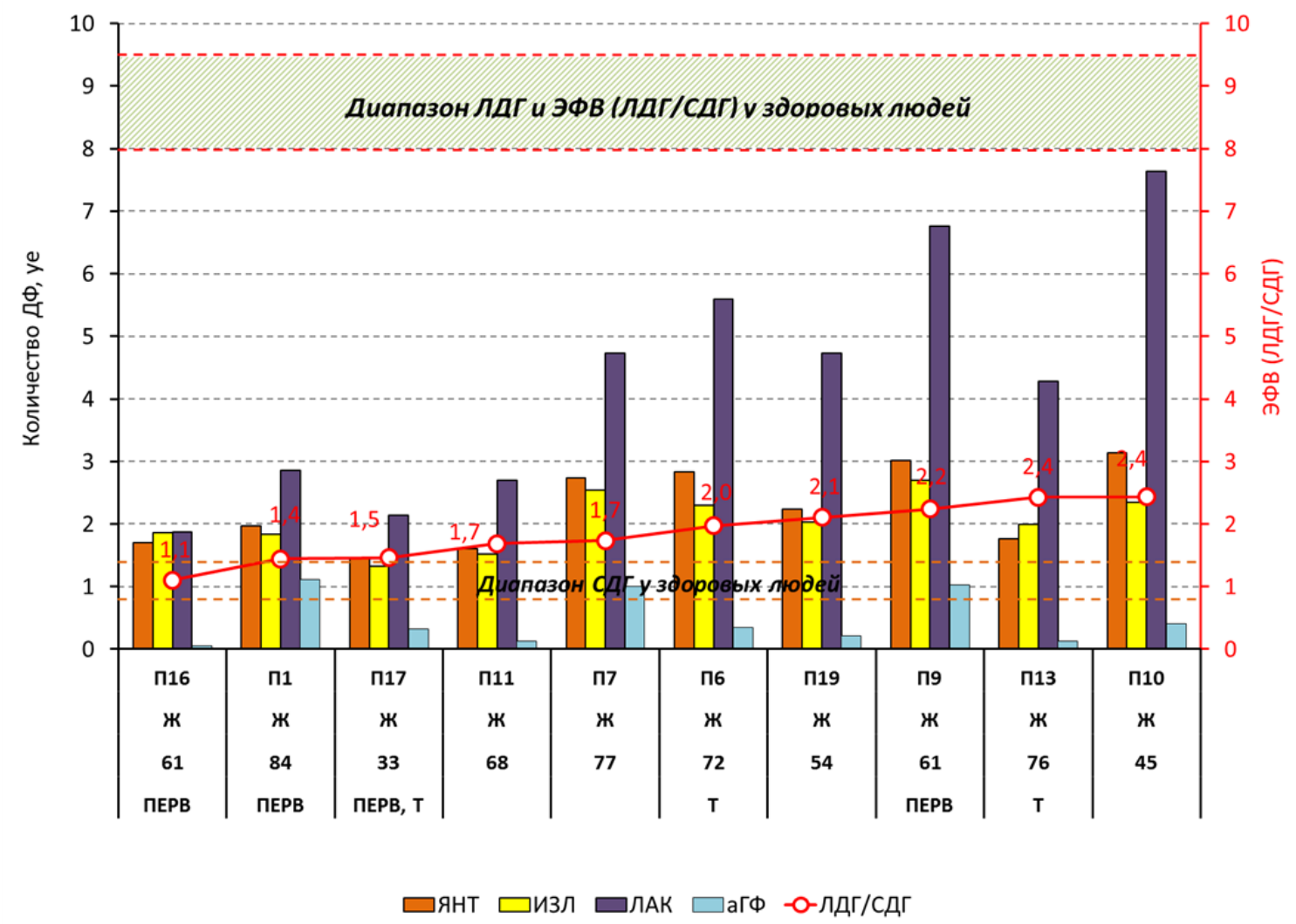

Рис. 5. Данные первого обследования 10-ти пациентов; выстроены в порядке увеличения ЭФВ. На рисунке нанесены диапазоны значений СДГ, ЛДГ и ЭФВ, характерные для здоровых взрослых людей (40-70 лет).

Данные диапазоны установлены в предыдущих исследованиях группы.

T- тяжелое состояние, ПЕРВ - обращение к врачу и лечение меньше 5-ти лет 


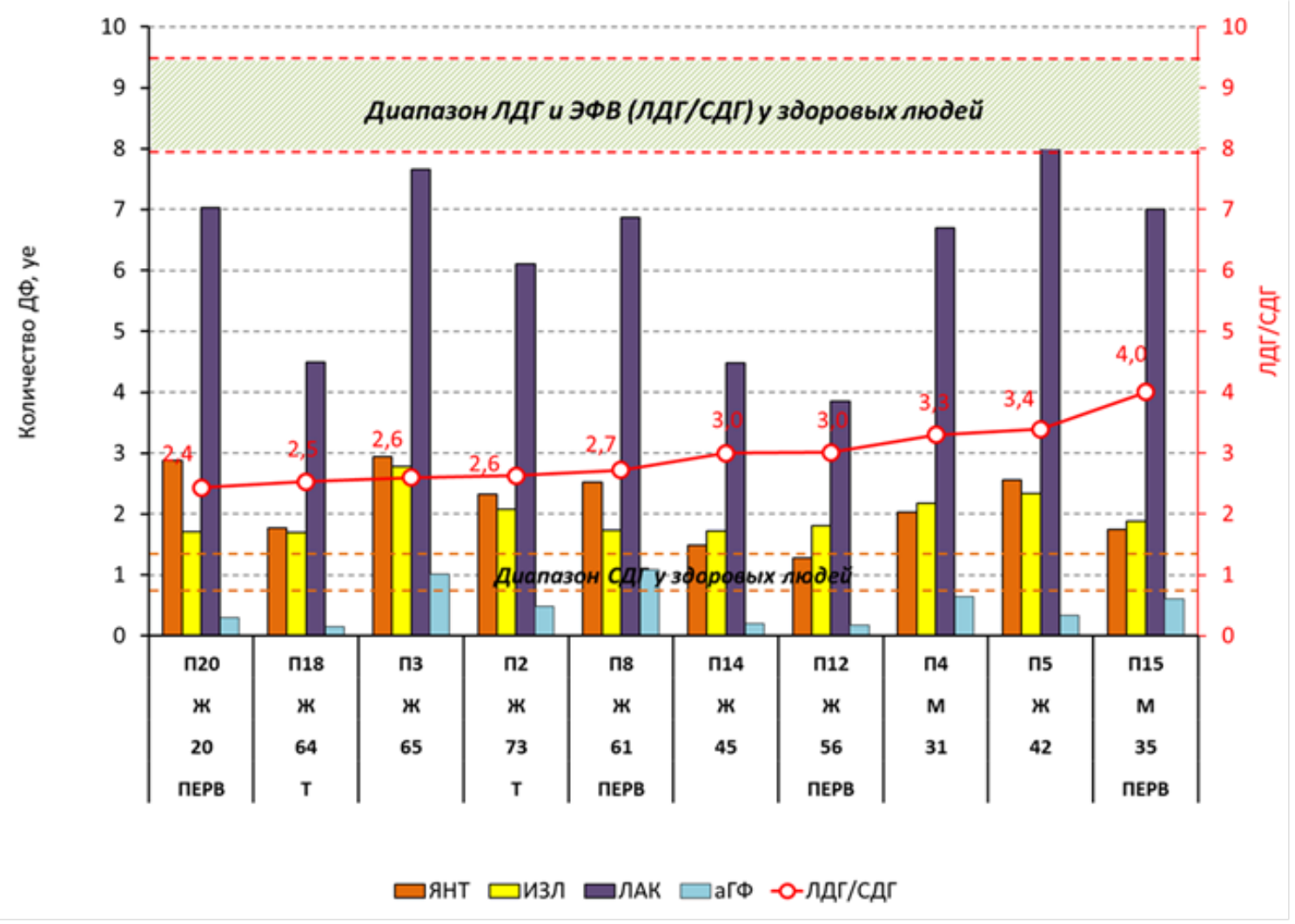

Рис. 5. Данные первого обследования еще 10-ти паџиентов; выстроены в порядке увеличения ЭФВ.

На рисунке нанесены диапазоны значений СДГ, ЛДГ и ЭФВ, характерные для здоровых взросльх людей (40-70 лет).

Данные диапазоны установлены в предыдущих исследованиях группы.

T- тяжелое состояние, ПЕРВ - обращение к врачу и лечение меньще 5-ти лет 


\section{ПРИЛОЖЕНИЕ № 11}

Показатели активности СДГ, ЛДГ и ЭФВ для каждого пациента в результате 4-х кратных обследований. Пациенты распределены по 2-м группам
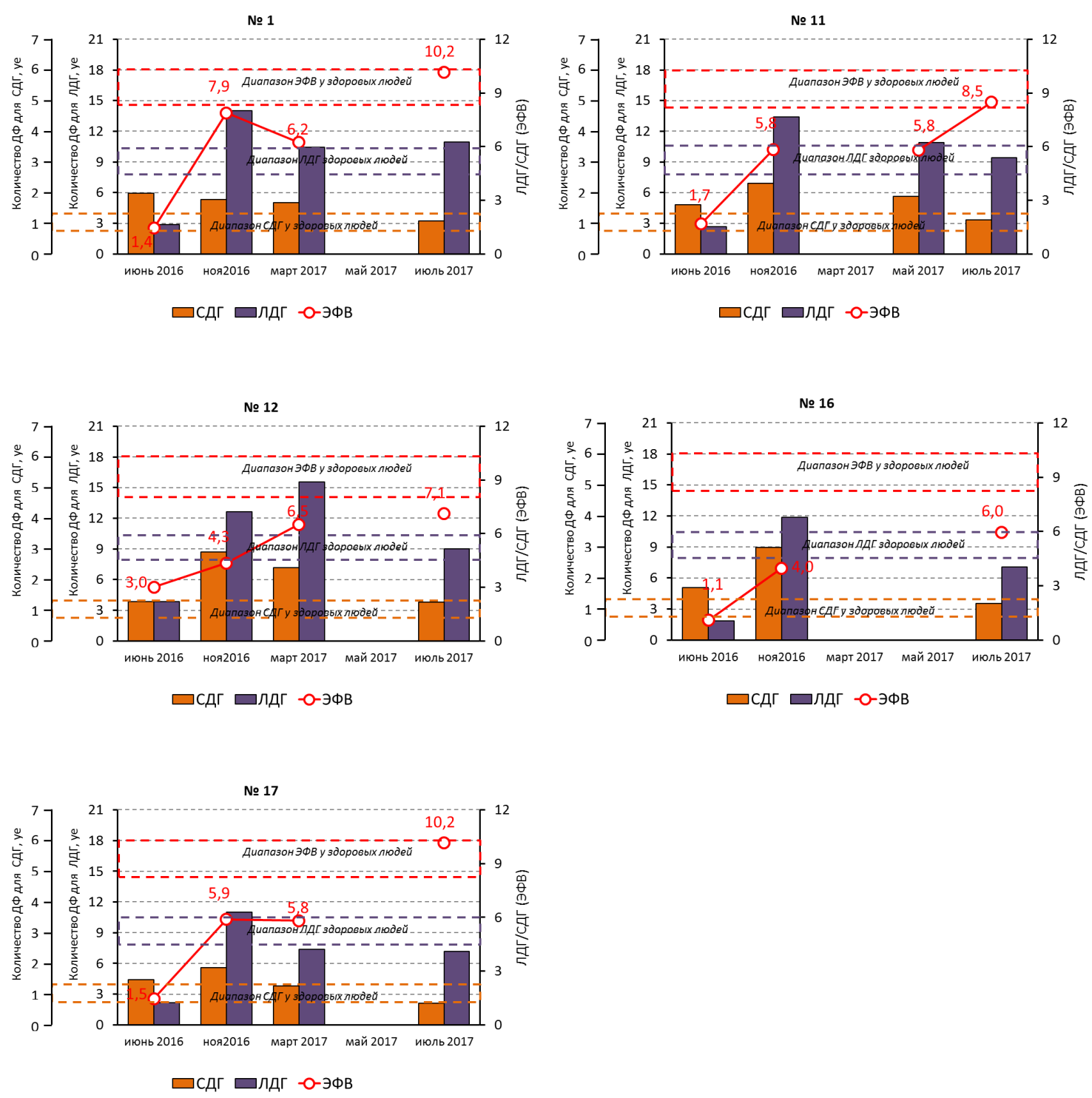

Puc. 6.

Группа 1. Крайне низкая начальная активность ЛДГ (средние значения $-2,7 \pm 0,8)$ и незначительно превышающая верхнюю гранииу зоны нормы начальная активность СДГ (1,6 $\pm 0,3)$.

ЭФВ очень слабый $-1,7 \pm 0,7$ за счет низкой ЛДГ 

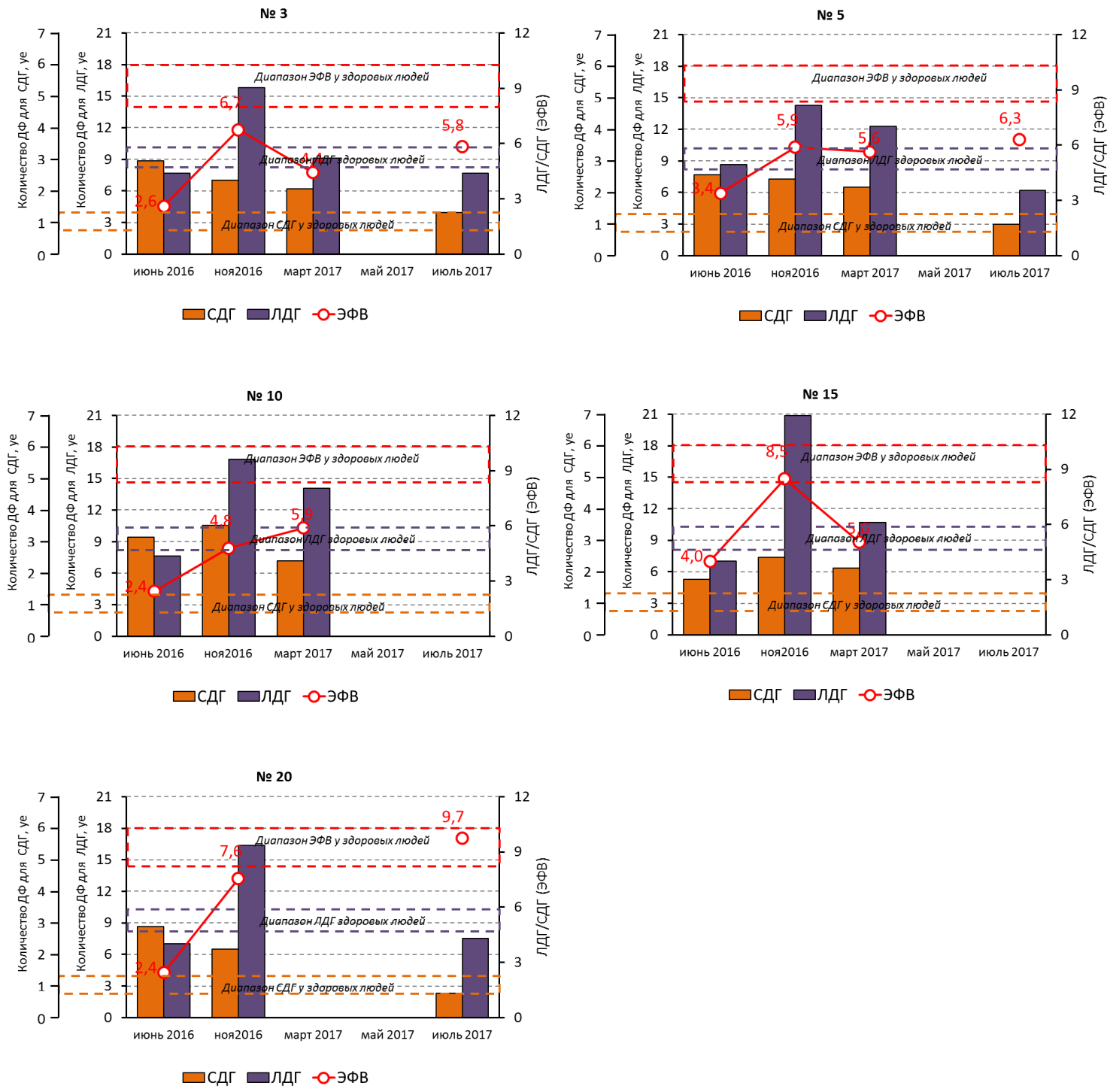

Рuc. 6.

Группа 2. Начальная активность ЛДГ (средние значения - 7,6 \pm 0,7) близка к зоне нормы и сопровождается значительно повышенной начальной активностью СДГ $(2,7 \pm 0,5)$. ЭФВ также низкий 3,0 0 0,7, но за счет увеличенной СДГ. 


\section{ПРИЛОЖЕНИЕ № 12}

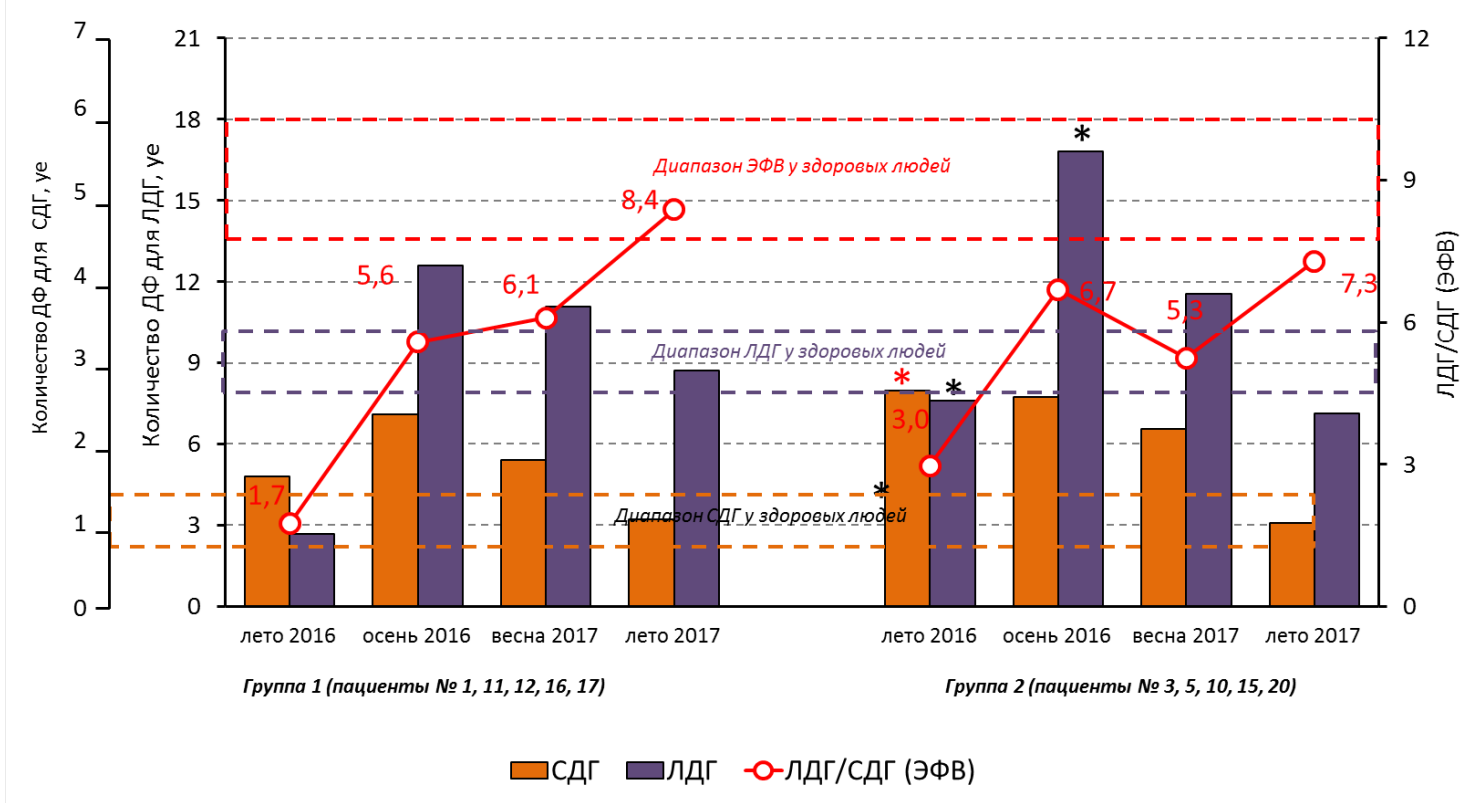

Рис. 7. Средние значения активности СДГ, ЛДГи ЭФВ для групп паииентов после 4-х кратных обследований 


\section{ПРИЛОЖЕНИЕ № 13}

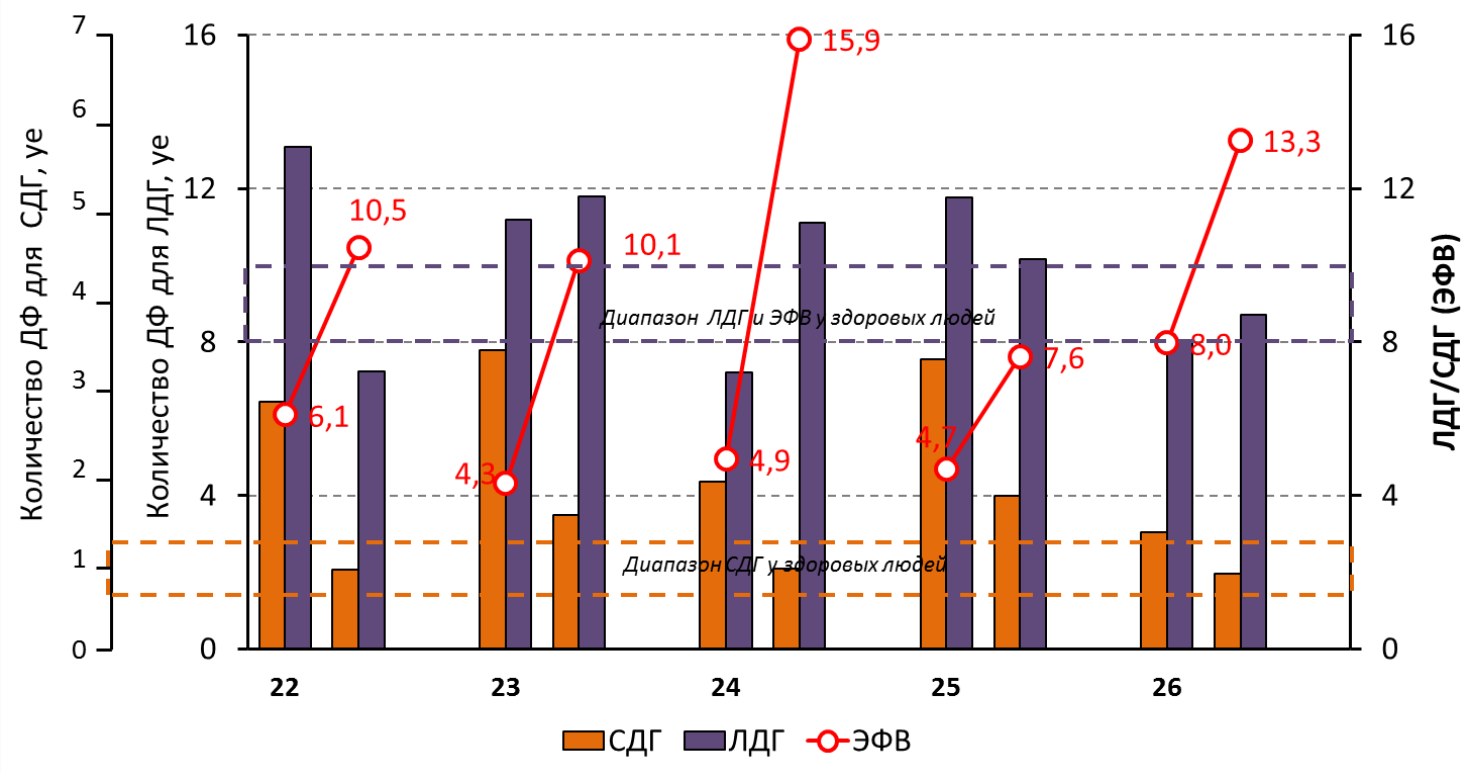

Рис. 8. Показатели активности СДГ, ЛДГ и ЭФВ для 5-ти «нативных» пациентов и их же после 3-х месяиев лечения 


\section{ПРИЛОЖЕНИЕ № 14}

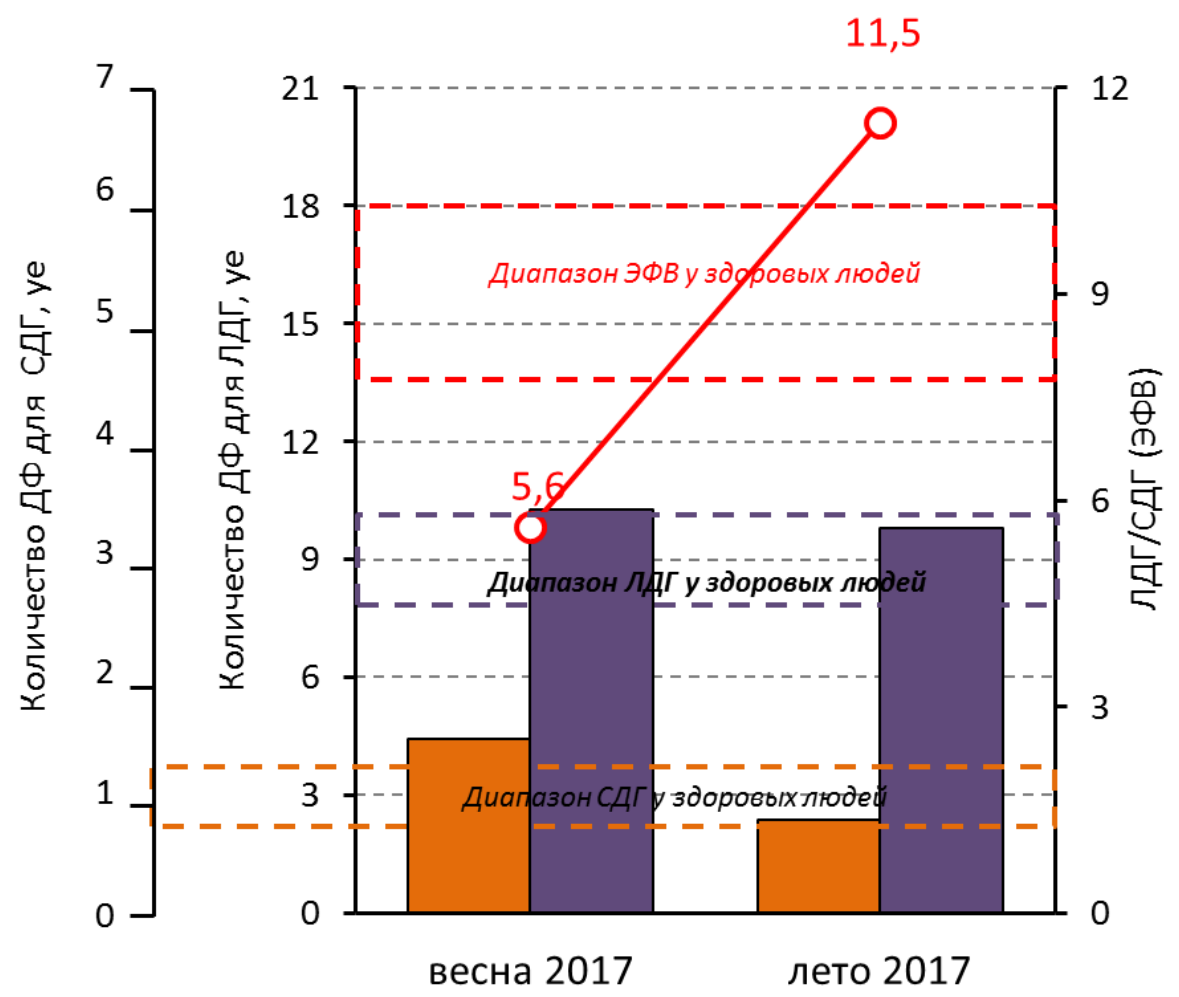

$\square$ Сдг $\square$ घдг -олдг/Сдг (ЭФВ)

Рис. 9. Средние значения активности СДГ, ЛДГи ЭФВ в группе «нативных» пациентов 
Косякова Нинель Ивановна,

Сандалова Татьяна Владимировна,

Шибаев Николай Викторович,

Панкратова Елена Витальевна,

Кондрашова Мария Николаевна,

Захарченко Марина Владимировна

\section{ПРИМЕНЕНИЕ ЦИТОБИОХИМИЧЕСКОГО МЕТОДА ИЗМЕРЕНИЯ АКТИВНОСТИ ФЕРМЕНТОВ В КАПЛЕ КРОВИ ПРИ ХРОНИЧЕСКОЙ ОБСТРУКТИВНОЙ БОЛЕЗНИ ЛЕГКИХ И БРОНХИАЛЬНОЙ АСТМЕ}

Методические рекомендации по внедрению результатов научно-поисковой работы

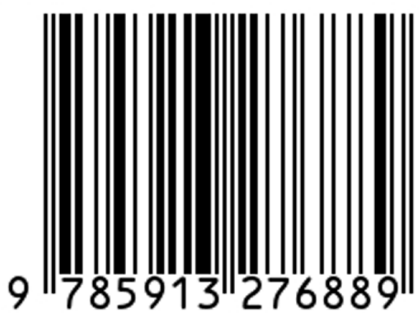

Технический редактор Доронкина Е.Н.

Подписано в печать 30.04.2021.

Бумага офсетная.

Гарнитура Times New Roman.

Формат 60×84 1/8.

Печать трафаретная. Печ. л. 8,5.

Тираж 500 экз. Заказ № 020-21.

Отпечатано в типографии ИД «Академия Естествознания», 440026, г. Пенза, ул. Лермонтова, 3 